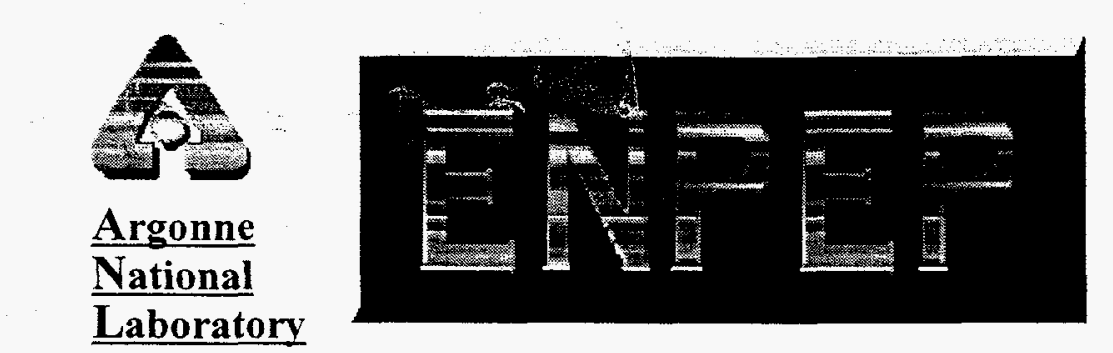

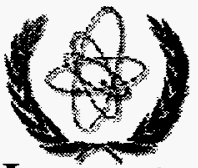

International

Atomic

Energy

Agency
$B=0 E I V E D$

NoV 051996

OSTI

\title{
ENergy and Power Evaluation Program
}

Absy

ANL/DIS/WWW- 91439

In the late 1970 s, national and international attention began to focus on energy issues. Efforts were initiated to design and test analytical tools that could be used to assist energy planners in evaluating energy systems, particularly in developing countries.

In 1984, the United States Department of Energy (DOE) commissioned Argonne National Laboratory's Decision and Information Sciences Division (DIS) to incorporate a set of analytical tools into a personal computer-based package for distribution in developing countries. The package developed by DIS staff, the ENergy and Power Evaluation Program (ENPEP), covers the range of issues that energy planners must face: economic development, energy demand projections, supply-and-demand balancing, energy system expansion, and environmental impact analysis.

Following the original DOE-supported development effort, the International Atomic Energy Agency (IAEA), with the assistance from the U.S. Department of State (DOS) and the U.S. Department of Energy (DOE), provided ENPEP training, distribution, and technical support to many countries.

ENPEP is now in use in over 60 countries and is an international standard for energy planning tools. More than 500 energy experts have been trained in the use of the entire ENPEP package or some of its modules during the international training courses organized by the IAEA in collaboration with Argonne's Decision and Information Sciences (DIS) Division and the Division of Educational Programs (DEP).

\section{You are visitor number}

000I03

For comments or suggestion send an e-mail to enpep@anl.gov 


\section{DISCLAMMER}

Portions of this document may be illegible in electronic image products. Images are produced from the best available original document. 


\section{DISCLAIMER}

This report was prepared as an account of work sponsored by an agency of the United States Government. Neither the United States Government nor any agency thereof, nor any of their employees, makes any warranty, express or implied, or assumes any legal liability or responsibility for the accuracy, completeness, or usefulness of any information, apparatus, product, or process disclosed, or represents that its use would not infringe privately owned rights. Reference herein to any specific commercial product, process, or service by trade name, trademark, manufacturer, or otherwise does not necessarily constitute or imply its endorsement, recommendation, or favoring by the United States Government or any agency thereof. The views and opinions of authors expressed herein do not necessarily state or reflect those of the United States Government or any agency thereof. 


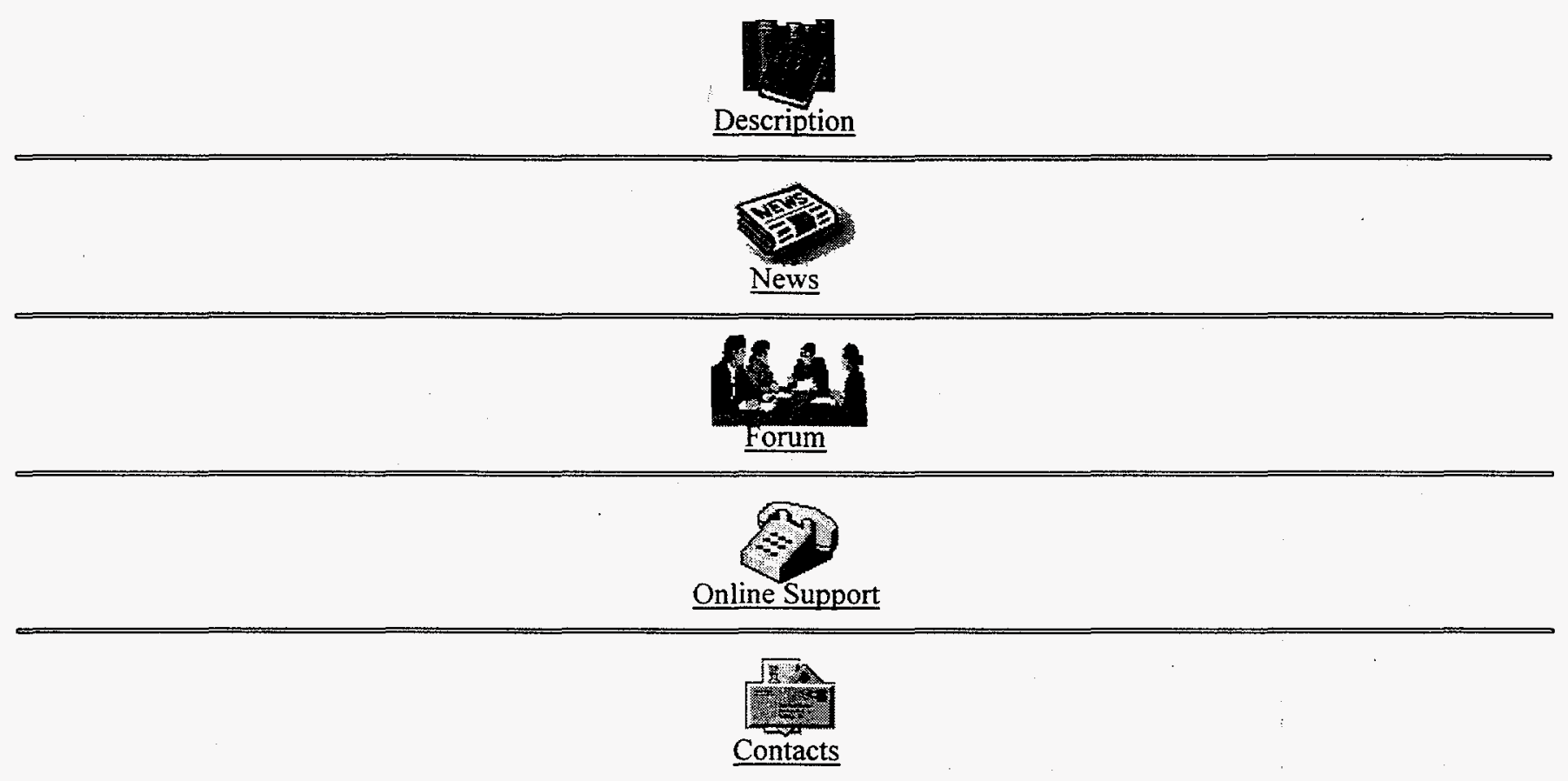




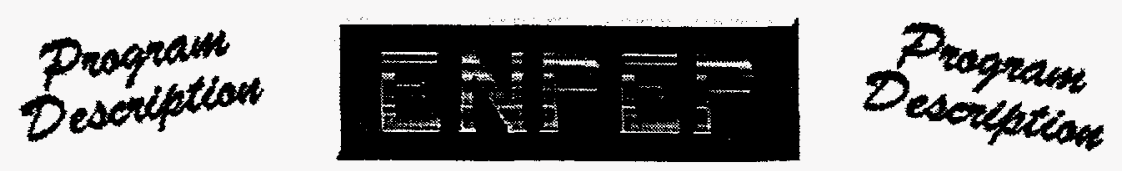

\section{Model description}

1. Summary

2. The ENPEP Modules

3. How ENPEP Works

A. Modules and Forms

B. Software

C. Data Organization

\section{Summary}

\section{Objective}

Integrated planning package used for evaluating a country's energy needs and corresponding resource requirements and environmental impacts.

\section{Procedures}

User is guided to nine modules through a hierarchy of menus and forms. Automated data-entry system is used for data input and tabular computations. Upper-level programming languages are used for simulation and optimization. Results are displayed in standard reports for reviewing and/or printing, and some modules allow for graphical displaying of results.

\section{Functions}

MACRO Module - formats macroeconomic growth projections for use in DEMAND

DEMAND Module - projects energy demands using macroeconomic projections

PLANTDATA Module - supplies electric plant data to BALANCE, ELECTRIC and ICARUS

BALANCE Module - computes equilibrium energy supply/demand balance over the study period

LDC Module - projects electricity demand information

MAED Module - determines energy demand based on end-use scenarios

ELECTRIC Module - determines least-cost development of electric supply system

ICARUS Module - calculates production costs and reliability of electric system

IMPACTS Module - calculates residuals of energy system and performs regulatory analysis

\section{Tools}

HARDWARE - IBM compatible PC with hard disk; color monitor; printer

SOFTWARE - DOS version 3.1 or higher, Windows 3.1 or higher

UTILITIES - Data dictionary; output paging routine; menu/forms system

\section{The ENPEP Modules}

The Energy and Power Evaluation Program is an integrated system for use on IBM or IBM-compatible microcomputers. It is a modular system consisting of: 


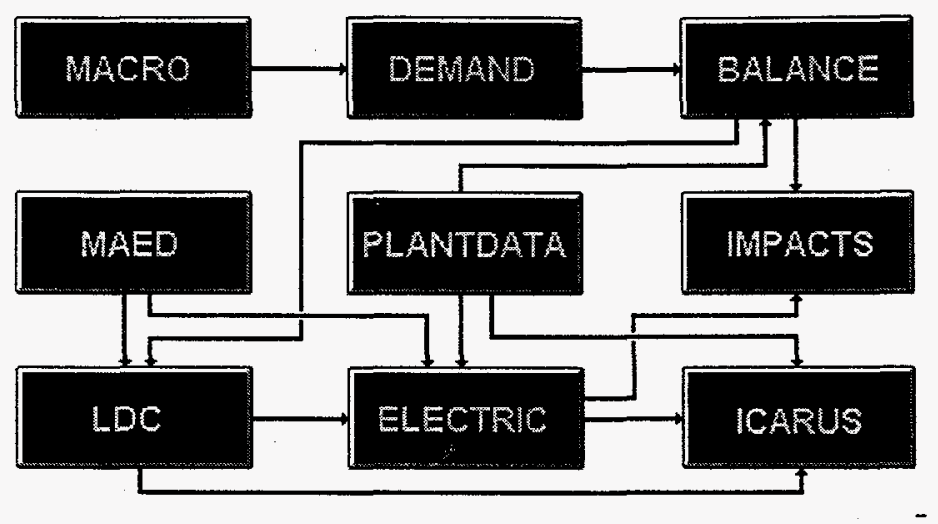

1. The MACRO Module, which allows the user to specify general data and format macroeconomic projections.

2. The DEMAND Module, which projects energy demands for the BALANCE Module based on growth information from the MACRO Module.

3. The PLANTDATA Module, which formats technical data on electric generating plants for the BALANCE and ELECTRIC modules.

4. The BALANCE Module, which performs an energy supply/demand balance using growth projections from DEMAND and power plant characteristics from PLANTDATA modules.

5. The LDC Module, which allows the user to coordinate electric sector information from the previous modules, and to supply additional information about electric LDC calculations.

6. The MAED Module, which allows the user to simulate different socioeconomic and technical development scenarios for the country to determine the resulting energy demand and, if desired, to provide electricity demand forecasts which can be used for the ELECTRIC module.

7. The ELECTRIC Module, which selects a minimum cost generation supply system to meet electric demand and reliability goals within other user imposed constraints.

8. The ICARUS Module, which performs detailed production cost and reliability calculations for a specified electrical generating system.

9. The IMPACTS Module, which serves as a decision aid by integrating information about energy supply system resource requirements and environmental impacts.

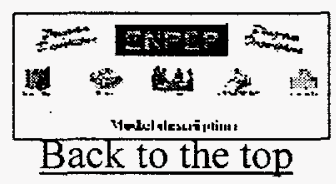

\section{How ENPEP works}

\section{A. Modules and Forms}

ENPEP is a modular system consisting of nine parts; each module deals with a specific aspect of the energy and power evaluation process. This modular organization produces several benefits: the user may run each module independently, and the results can be analyzed and checked for consistency before proceeding with the next module.

All major functions of ENPEP are controlled by the user through the use of menus and forms that appear on the PC screen. By making selections and entering relevant data, the user is guided through the nine modules. The menus of ENPEP form a hierarchy, and each path of the hierarchical tree performs a specific function for a module. Within each form are three levels of "help" information. Associated with each field is a one-line message that is automatically displayed at the bottom of the form page. A second level help screen is displayed when the user presses the "F1" key; it describes how to use the forms package itself. At the third level, a help abstract can be examined on the PC by pressing the "F2" key. 


\section{B. Software}

Through the use of menus and forms, and by sharing common data through the ENPEP data dictionary, the nine modules of ENPEP have been integrated into a user-friendly system.

Information used and generated by ENPEP is organized within a planning study, and although ENPEP's modules may be used independently, a planning study always has nine modules associated with it. Within a single module, the user may process data several times by iterating through a series of cases or within a single case. Information entered for a previous case can be copied to a new case and then changed as necessary. Input and output from each of these cases, as well as relevant status information, can be stored in the data dictionary for future use.

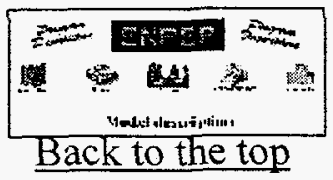

\section{Data Organization}

The current version of ENPEP allows the user to go through different modular chains to accomplish a case study or eventually a planning study. In design, each module can be run independently or data can be obtained from a previously executed module if so desired. ENPEP allows automatic transmission of data between modules. The three suggested chains for allowing this transmission are :
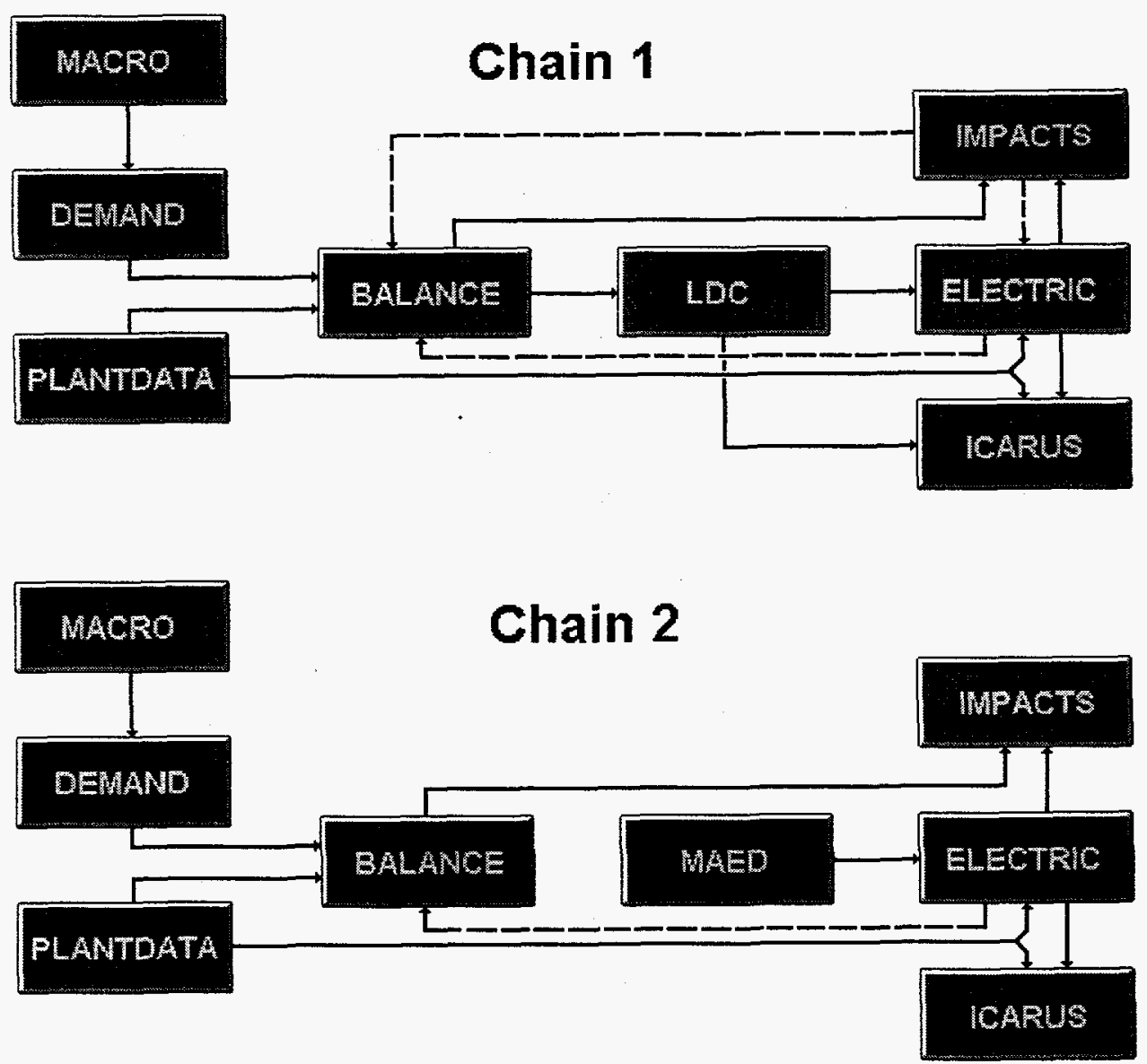


\section{Chain 3}

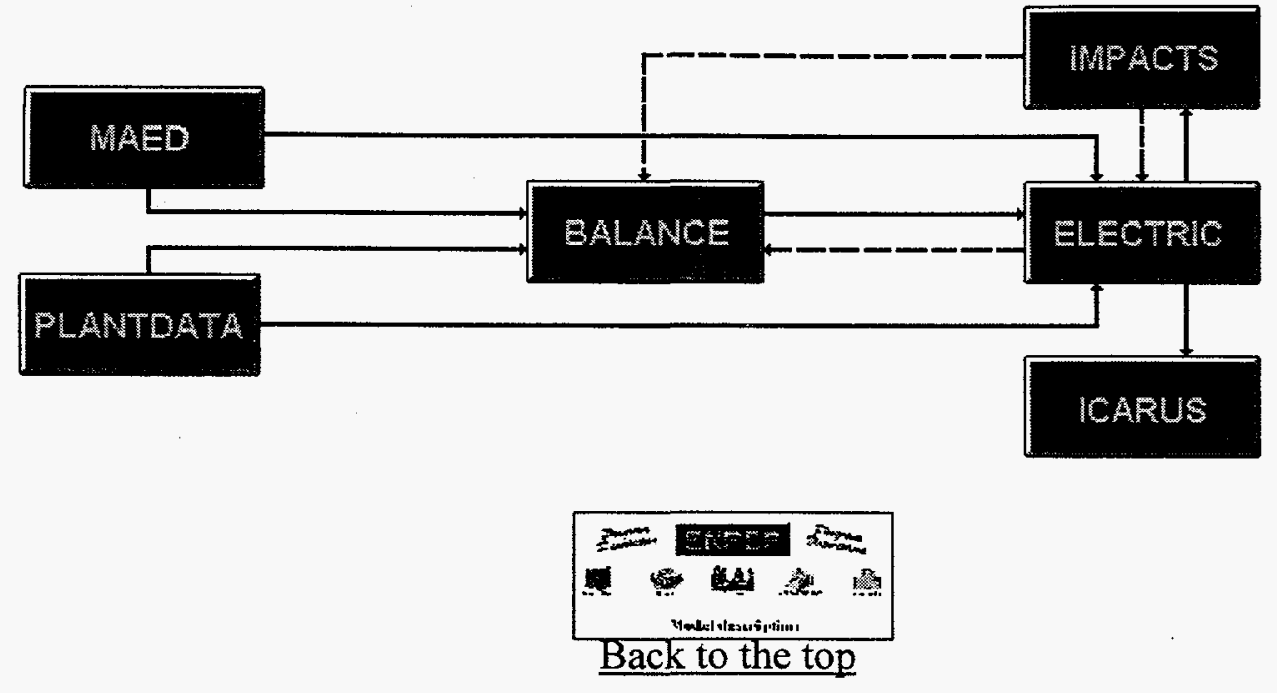




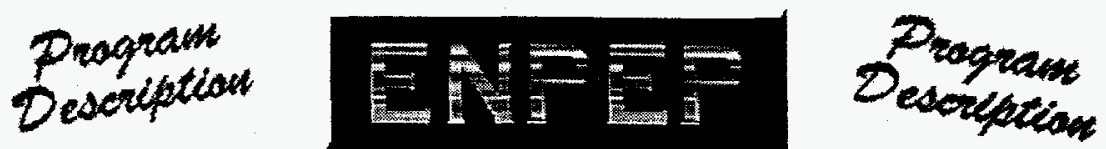

\section{MACRO Module}

\section{MACRO Structures User-Supplied Economic Growth Analysis}

\section{INPUT}

Time-series

extrapolation

Inputioutput

model

- Econometric

model

Other molel
OUTPUT

Formatted

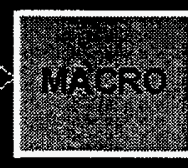

Grawth

Projection

The MACRO module is designed as interface between ENPEP and other economic analysis tools. MACRO itself is not an economic planning model. Rather, it allows the user to format the results of economic studies into a structure that can be used by the other modules in ENPEP. The MACRO module performs five main functions:

- Defines the planning period

- Processes currency conversions

- Processes GDP growth projections

- Processes population growth projections

- Processes special parameter growth projections

In the output reports, MACRO provides both tabular and graphical displays of the GDP, population, and special growth parameters by sector, subsector, or intermediate aggregations. Each of the parameters entered into MACRO is given a unique identifying code. This allows the user to apply the growth in that parameter to some portion of the energy demand in the DEMAND module.

For more information send an e-mail to enpep@anl.gov 


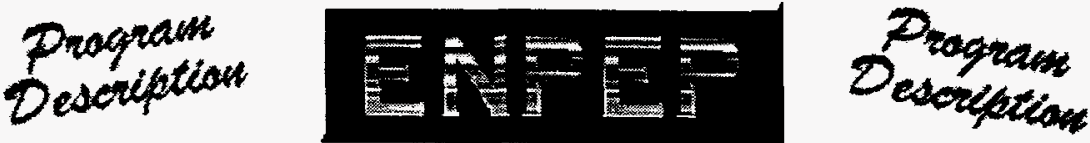

\section{DEMAND Module}

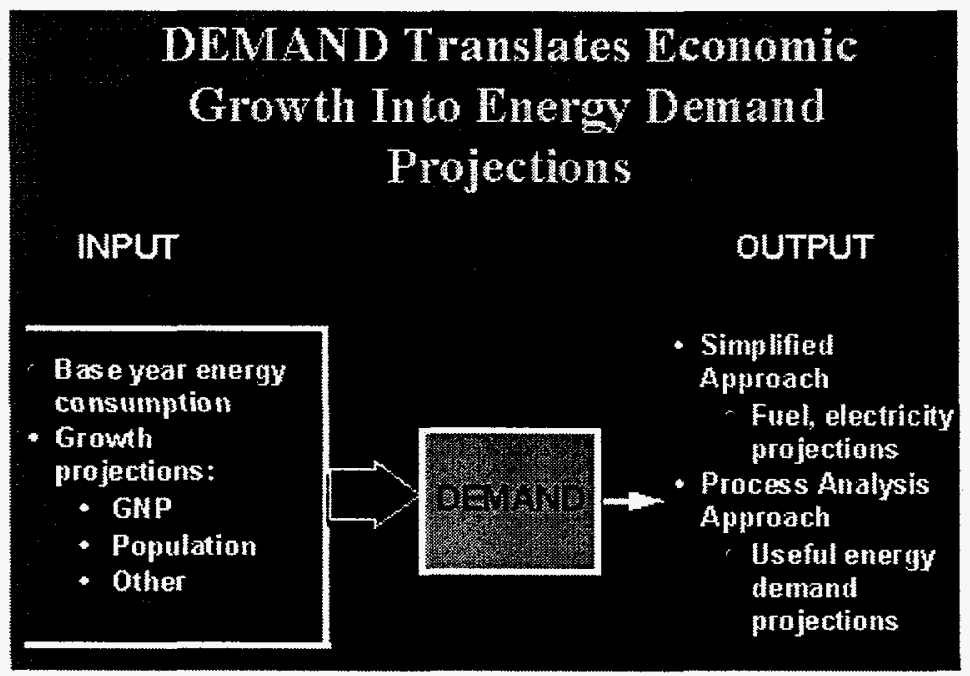

The DEMAND module is designed to generate projections of energy demand that are tied to the growth rates (GNP, population, or special) input into the MACRO module. By allowing for an explicit link to economic and other variables, DEMAND allows the user to see how these parameters might affect energy use. Numerous variations can be tested to evaluate the effect of changes in the parameters on energy demand. In carrying out its analysis. DEMAND performs four basic functions:

- Defines energy units

- Processes base year energy consumption

- Processes base year useful energy demand (optional)

- Computes projected final energy demand (and/or useful energy demand)

The user is given a set of reports that cover the energy units that have been defined, the base year energy consumption by fuel type and sector, and the projected energy consumption (and/or useful energy demand) by sector. DEMAND also prepares a set of files that transmit demand growth rates for subsequent use in the BALANCE module.

For more information send an e-mail to enpep@anl.gov 


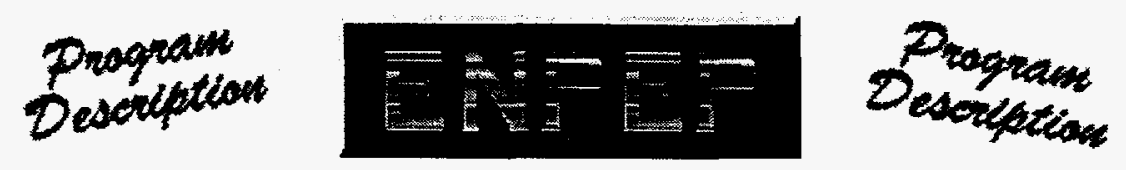

PLANTDATA Module

PLANTDATA was developed to serve the needs of other ENPEP modules that need descriptions of the electric generating system as input. BALANCE, ELECTRIC and ICARUS require detailed descriptions of every electric generating unit. PLANTDATA is intended to provide a consistent set of electric generating system data, while eliminating redundant data entry. PLANTDATA has two major components:

- Thermal generating unit data

- Hydroelectric plant unit data

A summary report on all data can be printed out and used as a reference document for a particular case study.

For more information send an e-mail to enpep@anl.gov 


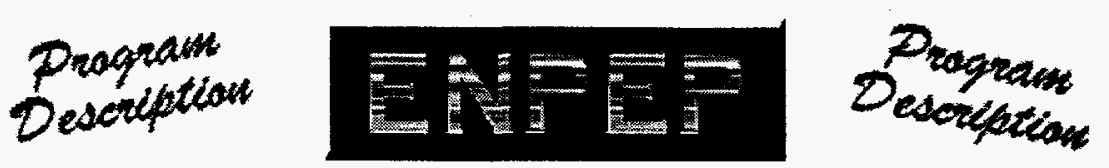

\section{BALANCE Module}

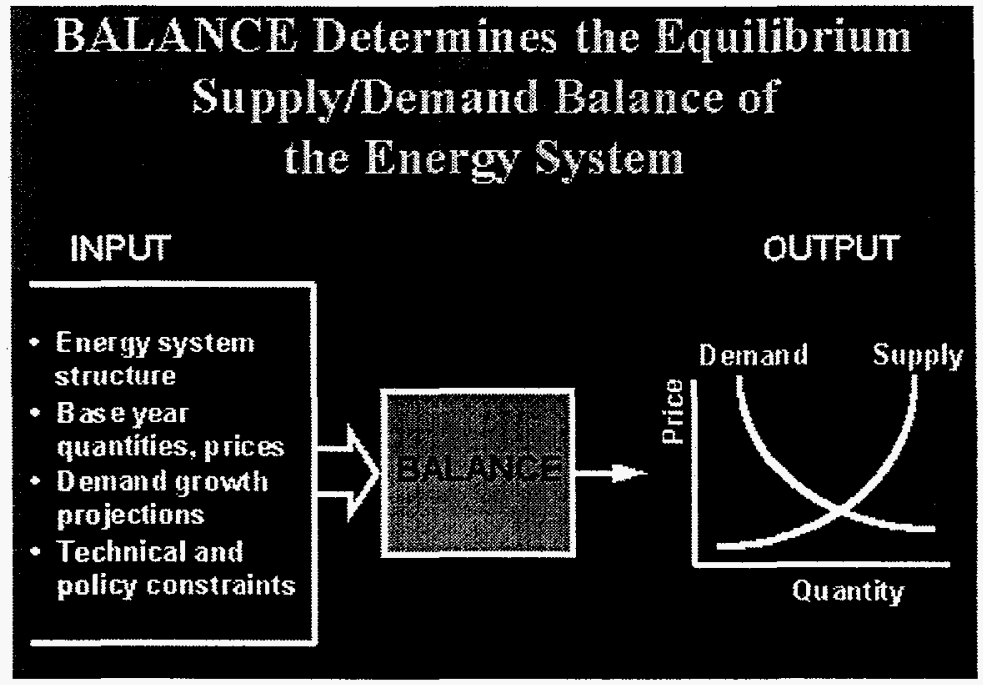

The central requirement of a comprehensive energy analysis is the evaluation of alternative configurations of the energy system that will balance energy supply and demand. The BALANCE module is designed to provide the planner with this capability.

BALANCE uses a non-linear, equilibrium approach to determine the energy supply and demand balance. In this formulation, an energy network is designed that traces the flow of energy from primary resource (e.g., crude oil, coal) to final or useful energy demand (e.g., gasoline for transportation, residential hot water, industrial steam). The network can be very simple or very detailed depending on the purpose of the analysis and data availability. Demand is sensitive to the prices of alternatives. Supply price is sensitive to the quantity demanded. BALANCE seeks to find the intersection of the supply and demand curves. In its operation, BALANCE simultaneously finds the intersection for all energy supply forms and all energy uses that are included in the network.

For more information send an e-mail to enpep@anl.gov 


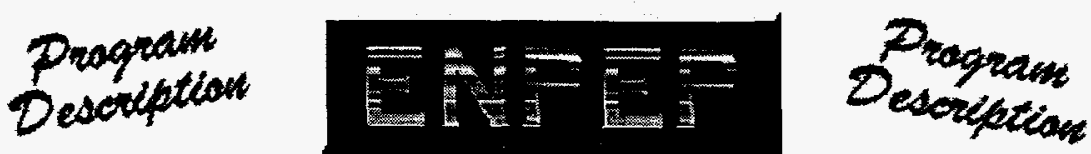

\section{Energy Network}

\section{Click the sector to see the detail network}

\section{Sample Energy Network}

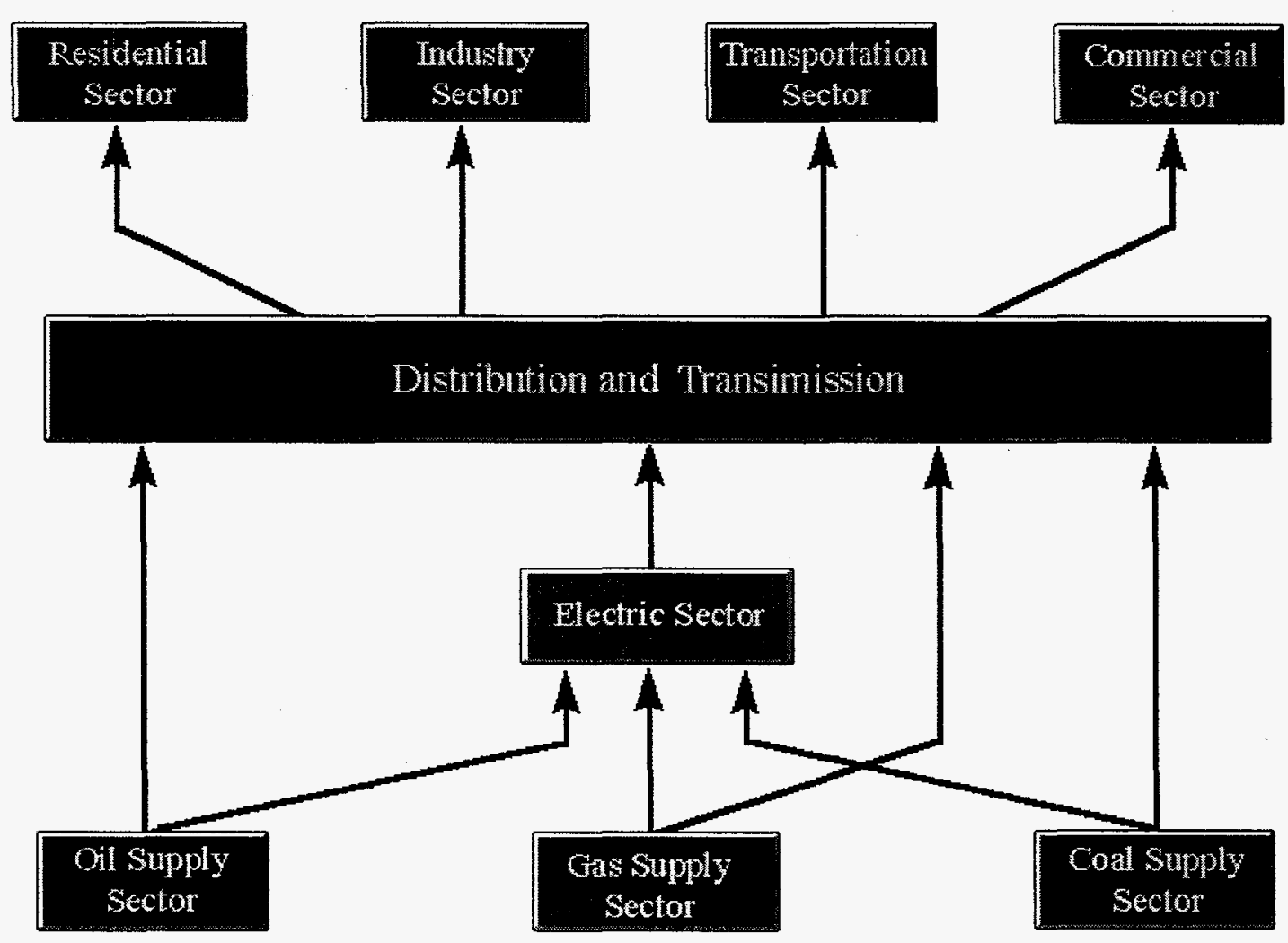

For more information send an e-mail to enpep@anl.gov 

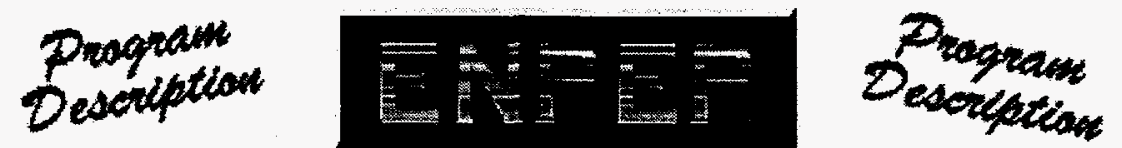

\section{Energy Network}

\section{Residential Sector}

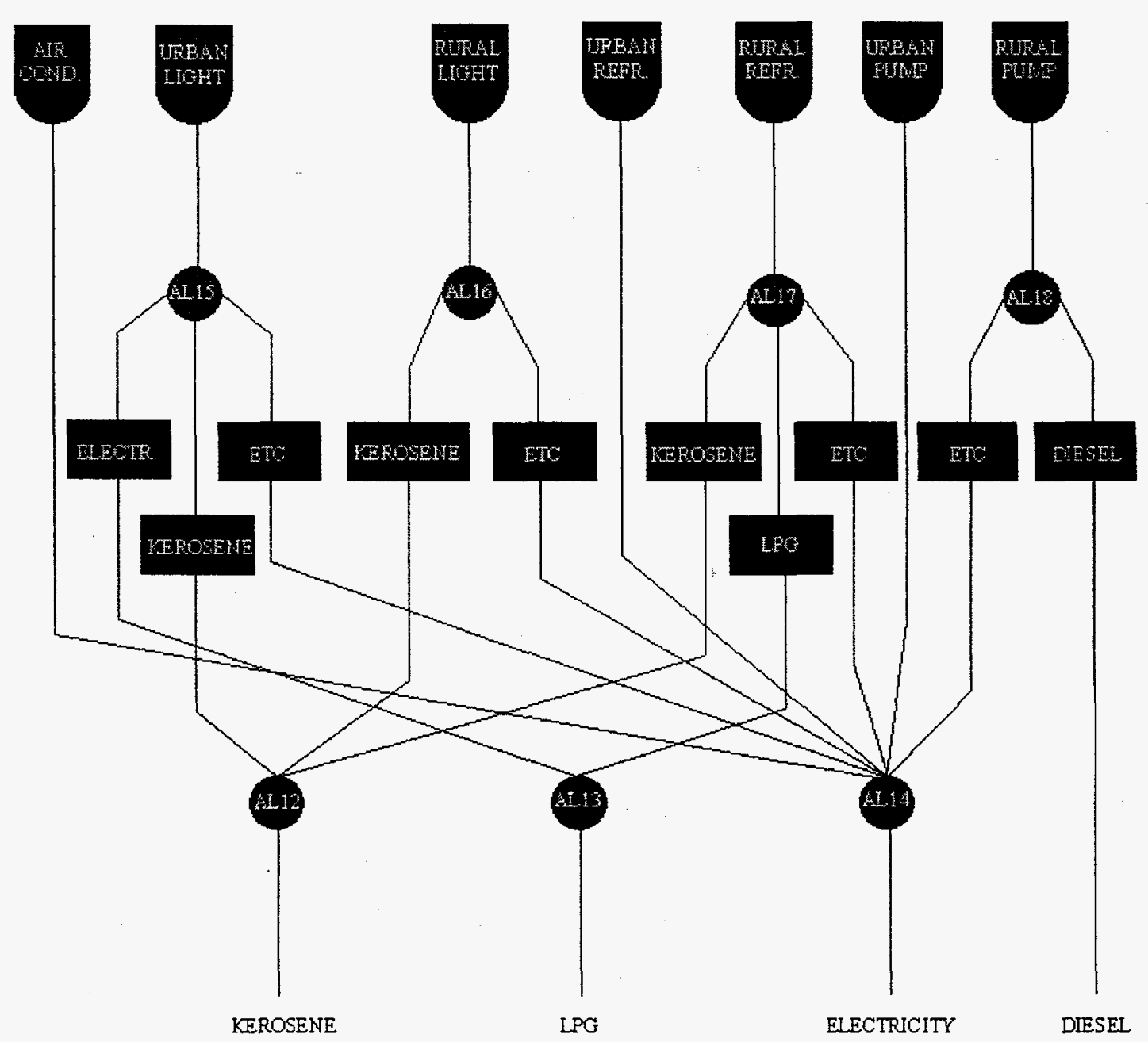

For more information send an e-mail to enpep@anl.gov

\section{Back to Energy Network}




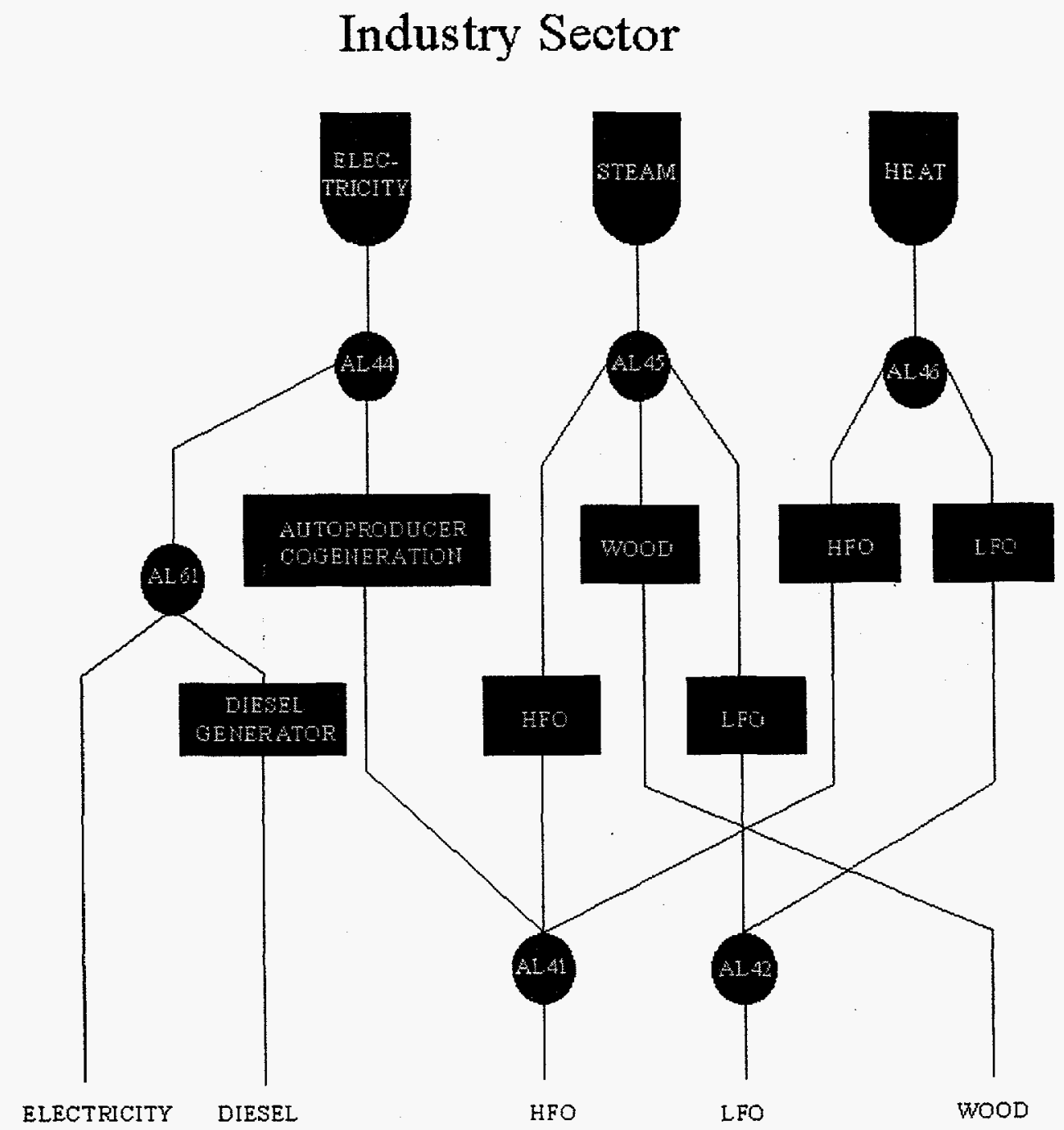

For more information send an e-mail to enpep@anl.gov

\section{Back to Energy Network}




\section{Transportation Sector}

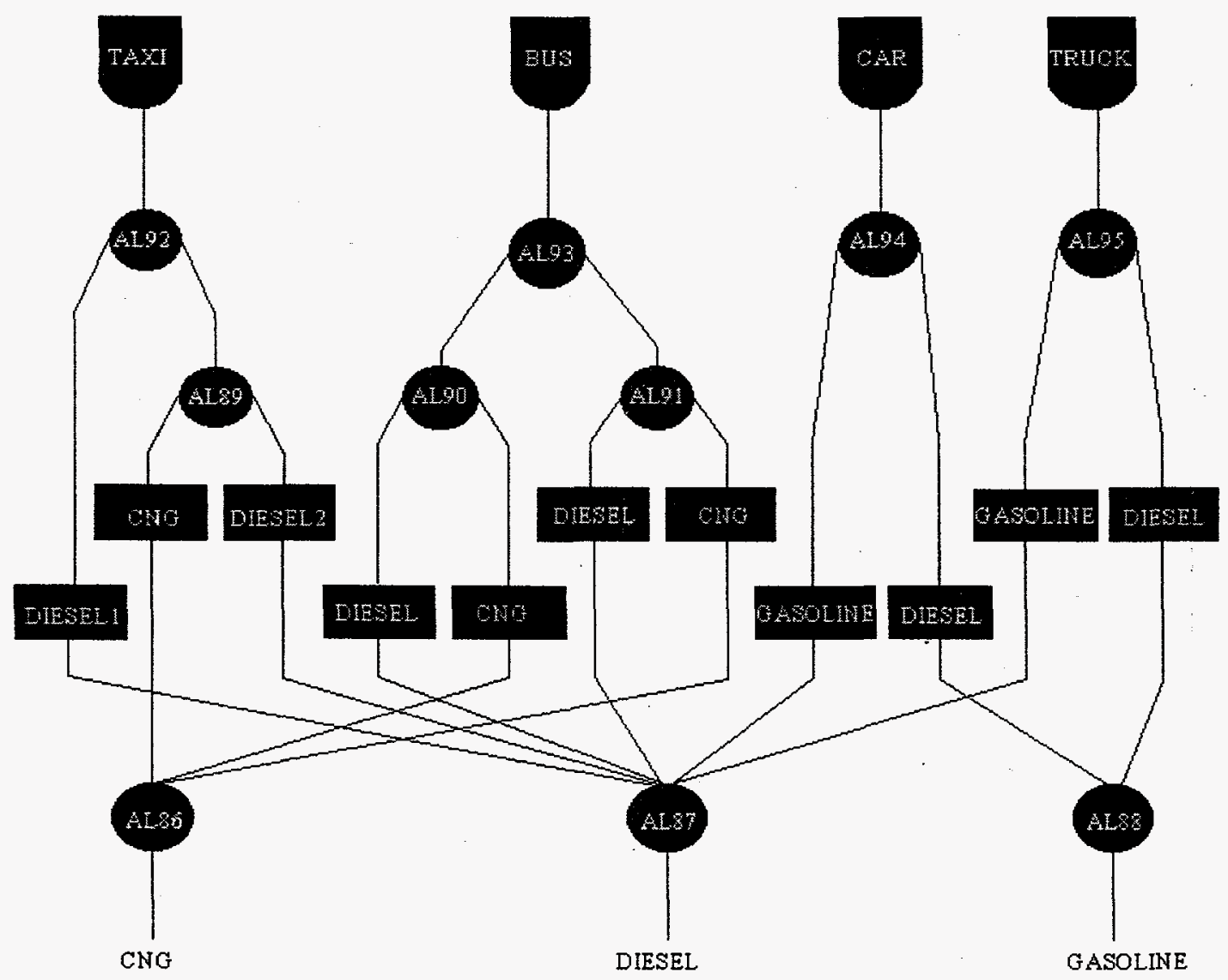

For more information send an e-mail to enpep@anl.gov

Back to Energy Network 


\section{Commercial Sector}

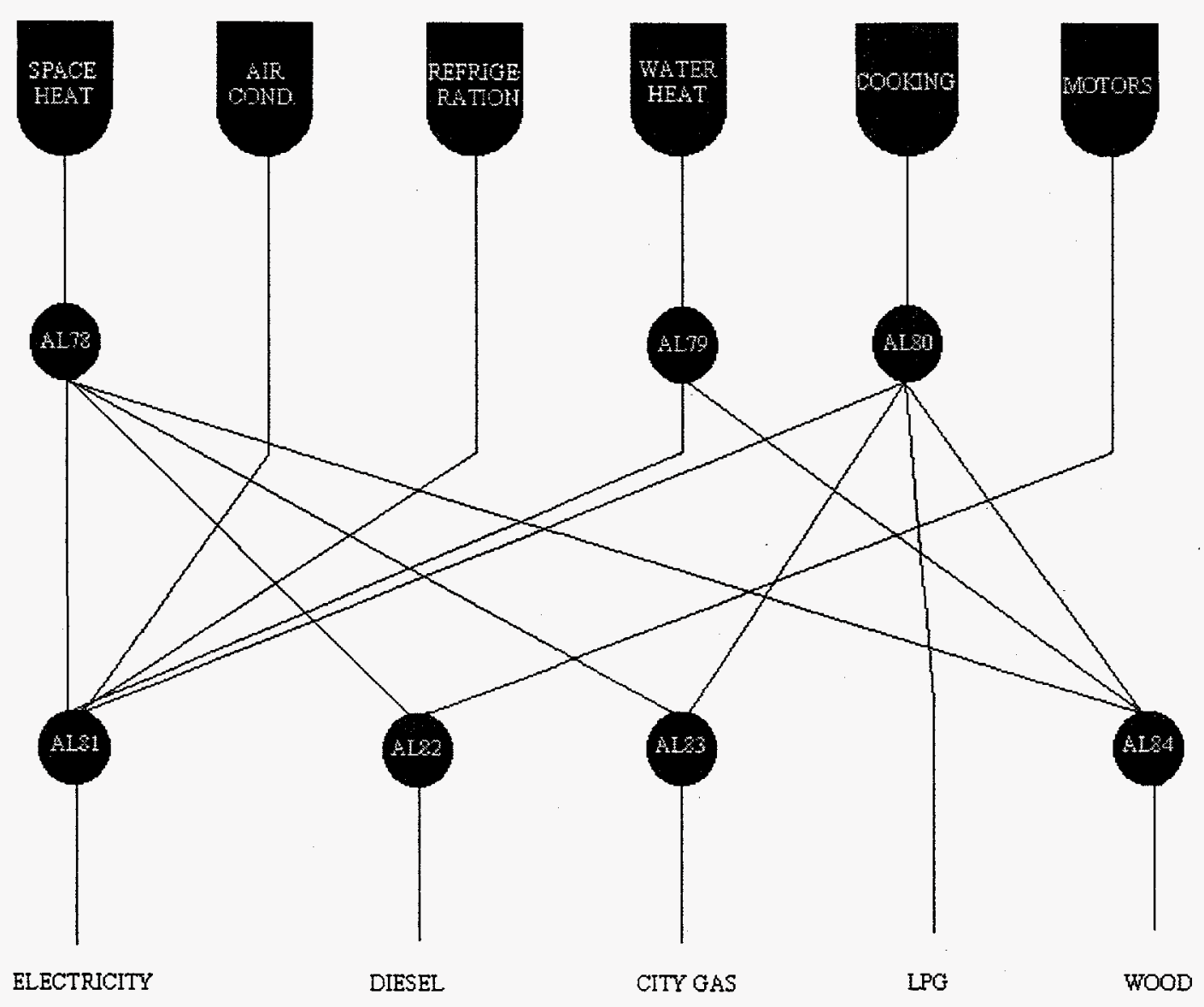

For more information send an e-mail to enpep@anl.gov

Back to Energy Network 


\section{Energy Network}

\section{Electric Sector}

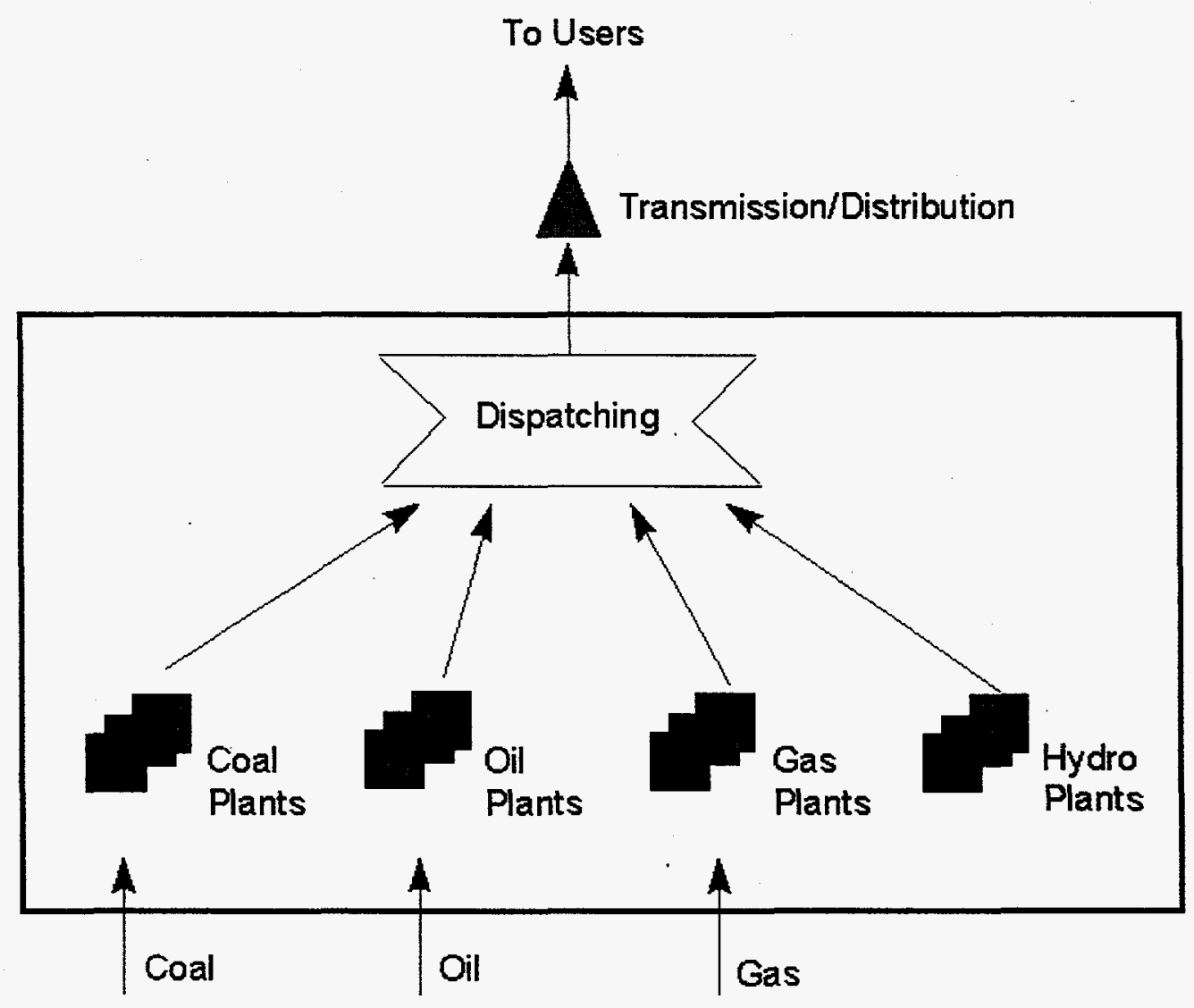

For more information send an e-mail to enpep@anl.gov

Back to Energy Network

Oil Sector

- Firal nil Distillate - Gasnline 


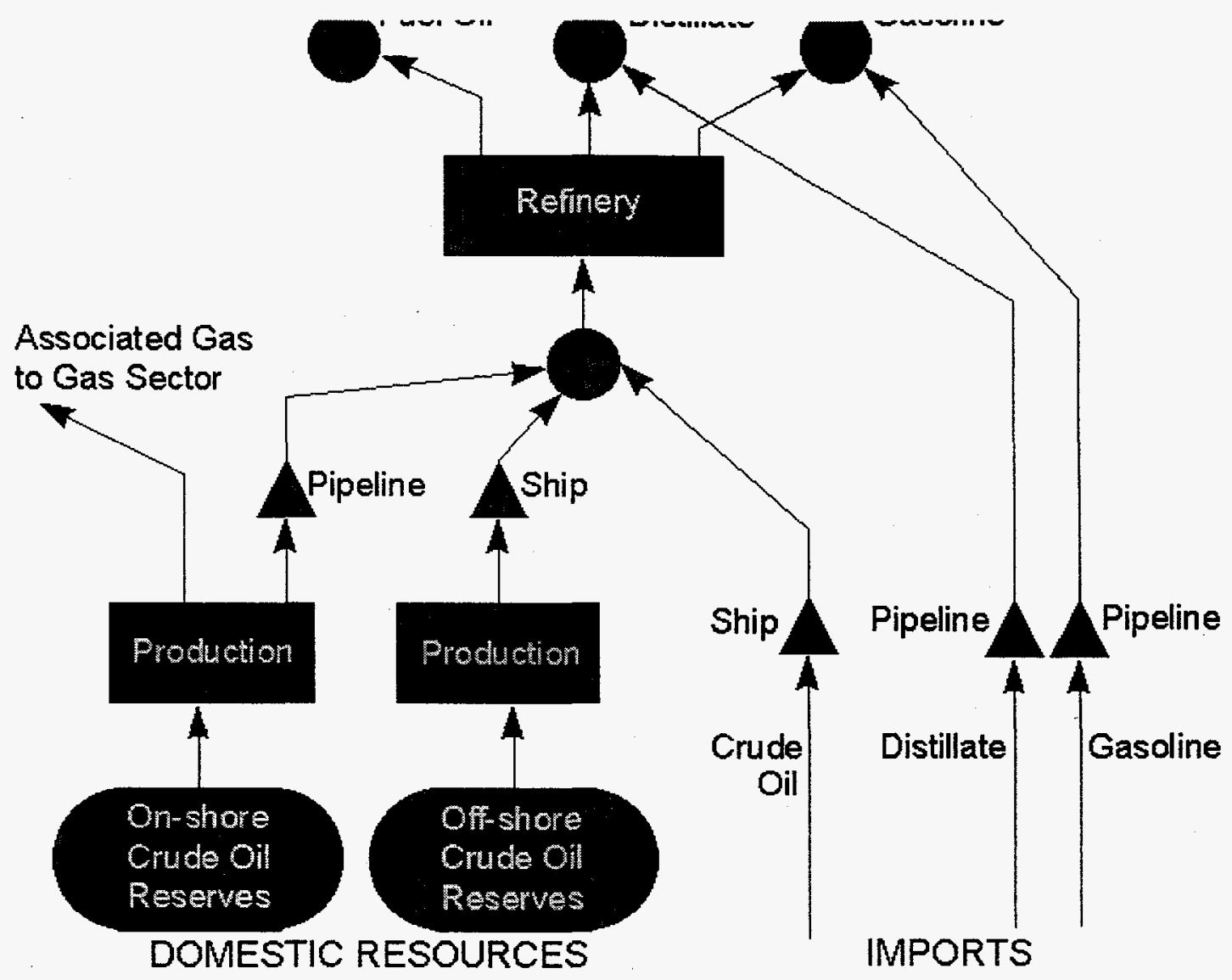

For more information send an e-mail to enpep@anl.gov

\section{Back to Energy Network}




\section{Gas Sector}

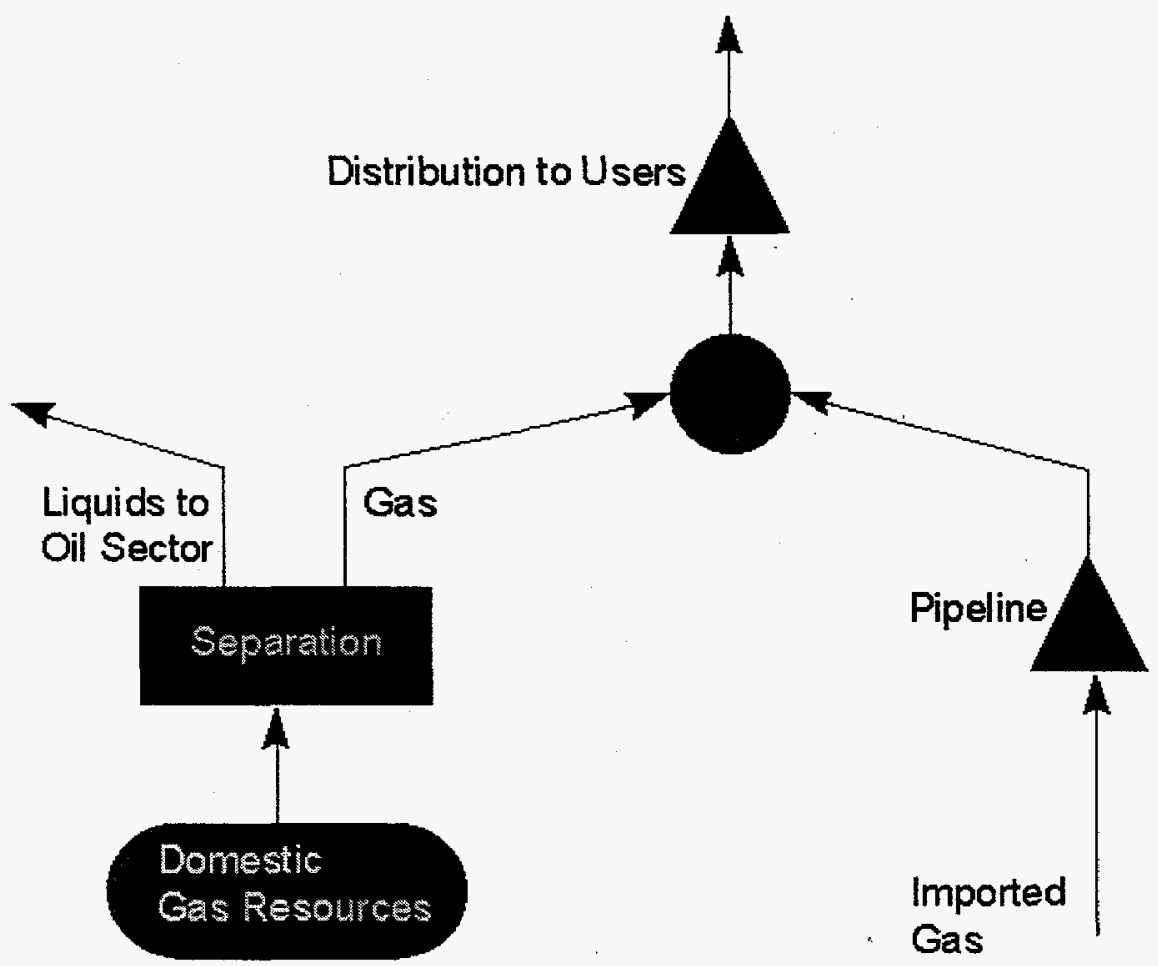

For more information send an e-mail to enpep@,anl.gov

\section{Back to Energy Network}




\section{Coal Sector}

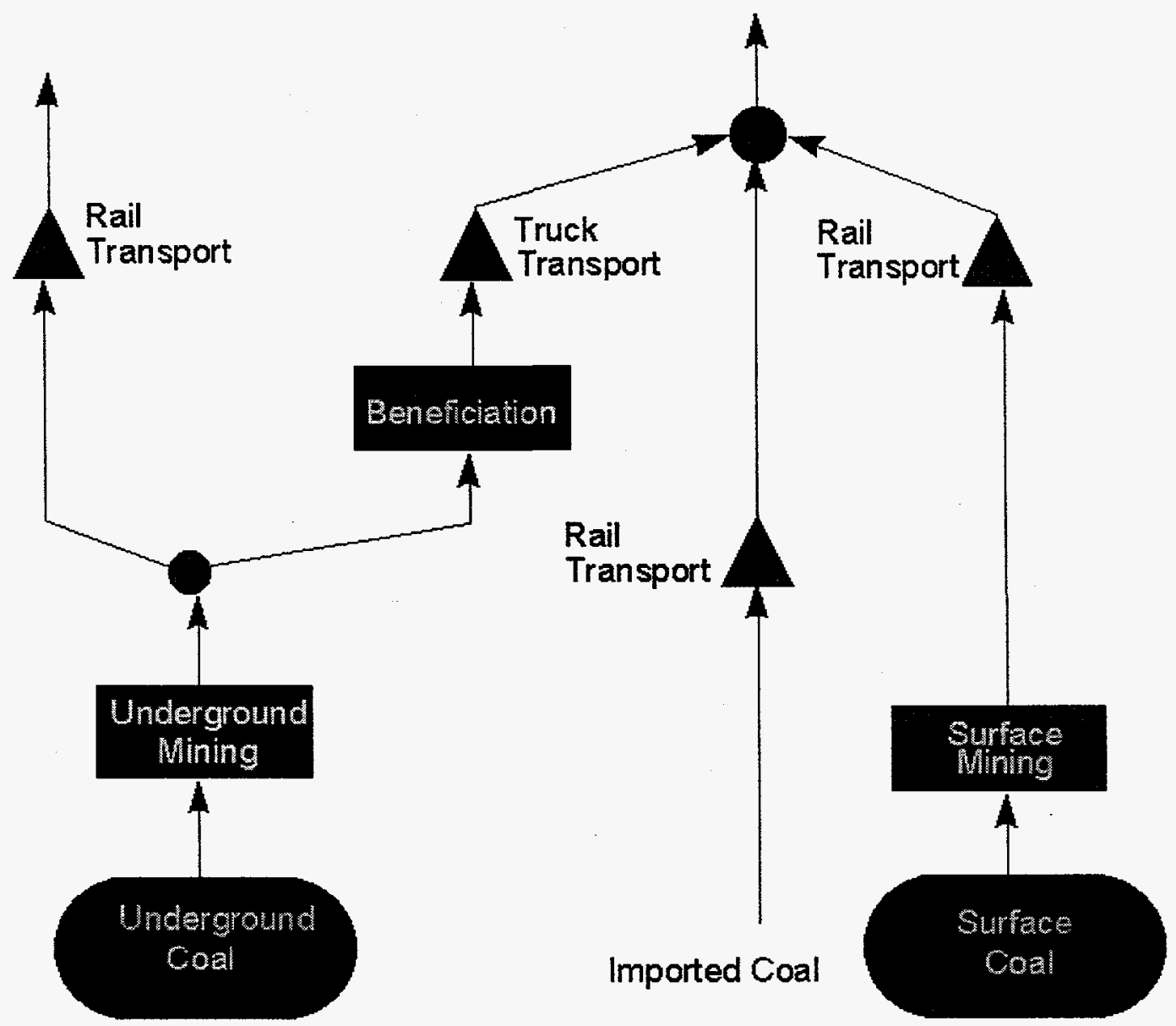

For more information send an e-mail to enpep@anl.gov

\section{Back to Energy Network}



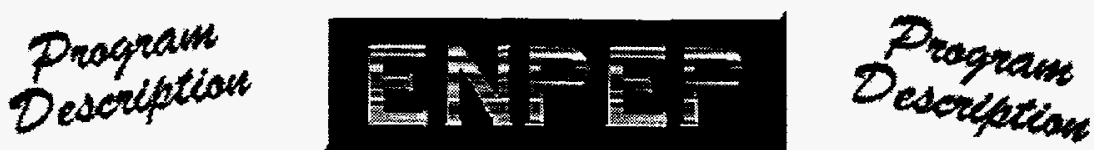

\section{LDC Module}

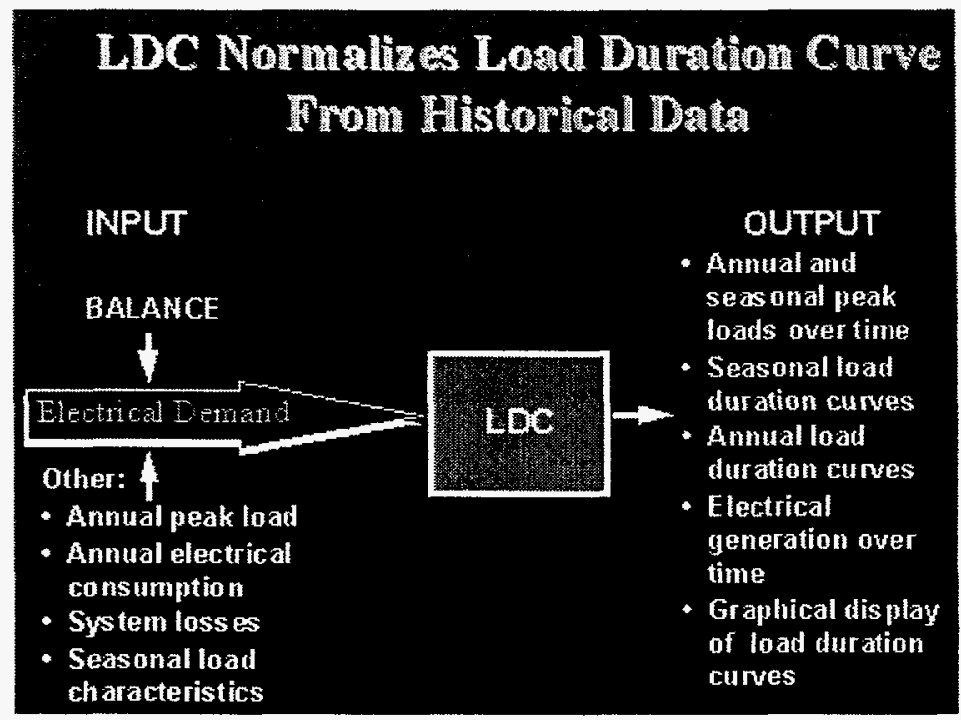

The main function of the LDC module is to process the historical information on hourly loads of an electric power system and to create normalized load duration curves needed by the ELECTRIC and ICARUS modules. The load duration curves can be created for up to 52 periods per year, and can be projected over the years of the study period according to the given load forecast (LDC is not a load forecasting model; the user must first run MAED or BALANCE or obtain the future load forecast by some other method). The load duration curves can be expressed either as a monotonically decreasing series of points or as a polynomial approximation. The most common polynomial approximation is with a 5-th degree polynomial.

The output of LDC is complete load input information for the ELECTRIC and ICARUS modules. Estimated load duration curves can be viewed with built-in graphics that can be rapidly accessed. Results of calculations are available in convenient tables.

For more information send an e-mail to enpep@anl.gov 


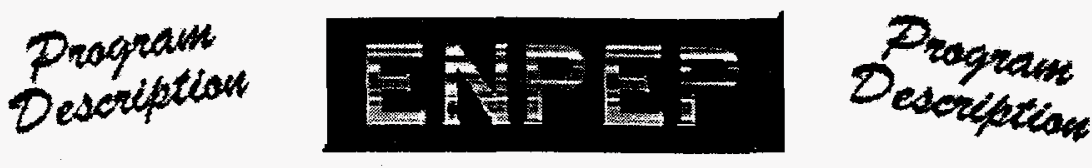

\section{MAED Module}

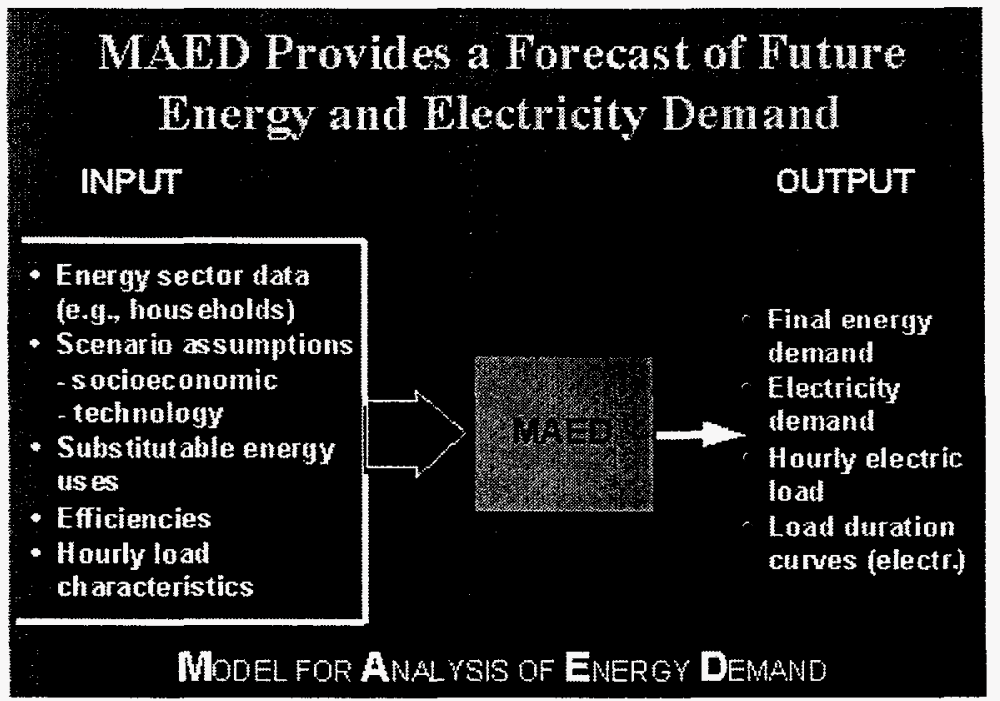

The Model for Analysis of Energy Demand (MAED) is a simulation model designed to evaluate medium- and long-term demand for energy in a country (or region). The model was developed by the International Atomic Energy Agency (IAEA) and was originally based on work done at the University of Grenoble in France. MAED offers an alternative approach to MACRO/DEMAND/BALANCE for estimating energy demand and electricity demand. The MAED model consists of four modules:

- Module 1 (energy demand) calculates the final energy demand by energy form and by economic sector for each reference year according to the various parameters describing each socio-economic and technical development (e.g., energy efficiency) scenario.

- Module 2 (hourly electric power demand) converts the total annual demand for electricity in each sector to the hourly demand, i.e., the hourly demand imposed on the grid by the respective sector.

- Module 3 (load duration curve) ranks the hourly demands imposed on the grid in decreasing order of magnitude and provides the load duration curve. The curve forms a basic input to the ELECTRIC module of ENPEP.

The output of the MAED model are detailed estimates of alternative energy forms used in each subsector for each year selected. The breakdown of demand by energy form and by economic sector is an important result of the analysis, which can serve as input information for detailed studies of the various sectors and optimization of the supply of the various energy forms. These analyses can be carried out with other models. Within ENPEP. the electric sector supply options are analyzed in detail. For this reason, the hourly electric load data can be used to produce load duration curves that serve as input to the ELECTRIC module of ENPEP.

For more information send an e-mail to enpep@anl.gov 


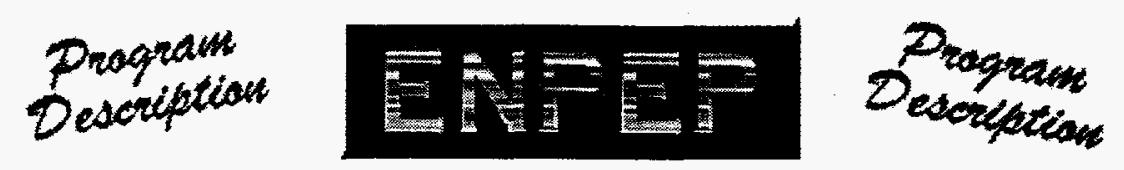

\section{ELECTRIC Module}

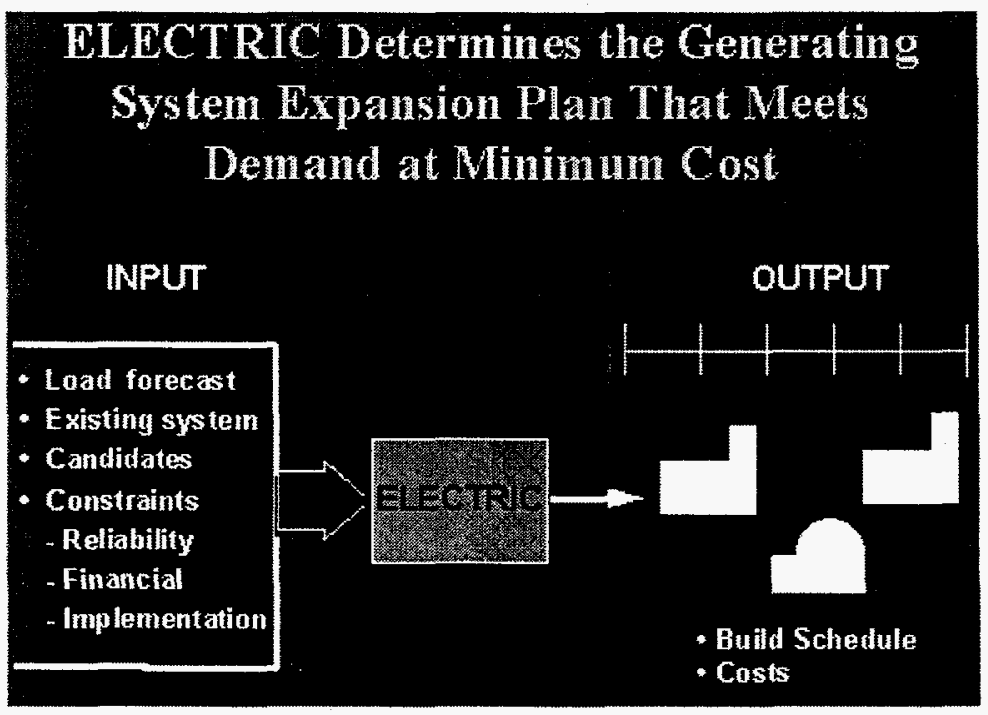

The ELECTRIC module is the microcomputer version of the Wien Automatic System Planning Package (WASP), which is the well-known mainframe electric system planning model distributed by the IAEA.

The objective of the ELECTRIC module is to determine the generating system expansion plan that adequately meets demand for electric power at minimum cost while respecting user-specified constraints. ELECTRIC is directed to long-term planning beyond a 10 year time horizon and is intended to address a number of critical issues in generation planning, including generating unit size, system reliability, details of the existing system, details of candidate plants forseen for the expansion of the system, seasonal variation in loads and hydroelectric availability, and appropriate simulation of future system operation.

A primary motivation for ENPEP's development is that evaluations of alternatives for expansion of electrical generating systems should not be conducted in isolation with respect to important related considerations, such as overall economic growth, demand for all forms of energy, supply of alternative energy forms, relative cost of energy forms, and environmental impacts of alternative supply systems. For this reason, ELECTRIC is integrated with the PLANTDATA, BALANCE, LDC, MAED, ICARUS, and IMPACTS modules of ENPEP. Although these components of ENPEP are fully integrated, the ELECTRIC module can be used as a stand-alone system.

ELECTRIC comprises the following eight submodules.

- LOADSY (Load System Description): Processes information describing the peak loads and load duration curves for up to 30 years. The objective of LOADSY is to prepare all the demand information needed by subsequent modules.

- FIXSYS (Fixed System Description): Processes information describing the existing generating system. This includes performance and cost characteristics of all generating units in the system at 
the start of the study period and a list of retirements and "fixed" additions to the system. Fixed additions are power plants already committed and not subject to change.

- VARSYS (Variable System Description): Processes information describing the various generating units (i.e., performance and cost characteristics) to be considered as candidates for expanding the generating system.

- CONGEN (Configuration Generator): Calculates all possible year-to-year combinations of expansion candidate additions that satisfy certain input constraints and that, in combination with the existing system, can adequately meet the electricity demand.

- MERSIM (Merge and Simulate): Considers all configurations put forward by CONGEN and uses probabilistic simulation of system operation to calculate the associated production costs, energy not served (ENS), and system reliability for each configuration. The module also calculates plant loading order, if desired, and makes use of all previously simulated configurations.

- DYNPRO (Dynamic Programming Optimization): Determines the optimum expansion plan as based on previously derived operating costs along with input information on capital cost, ENS cost, and economic parameters and reliability criteria.

- REMERSIM (Re-MERSIM): Simulates the system operation for configurations contained in the optimized solution. By providing a detailed output of the simulation, REMERSIM allows the user to analyze particular components of the production-cost calculation, such as unit-by-unit capacity factors for each season and hydroelectric condition.

- REPROBAT (Report Writer of WASP in a Batched Environment): Writes a report summarizing the total or partial results for the optimum or near-optimum power system expansion plan and fixed expansion schedules.

For more information send an e-mail to enpep@anl.gov 


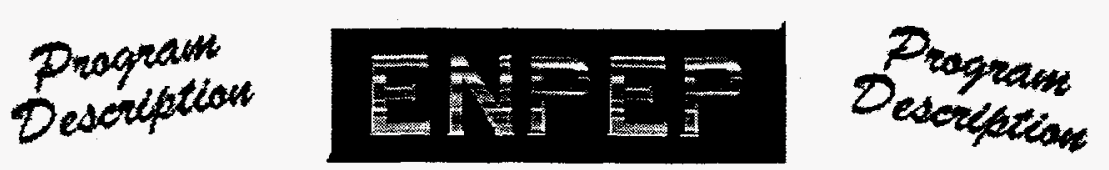

\section{ICARUS Module}

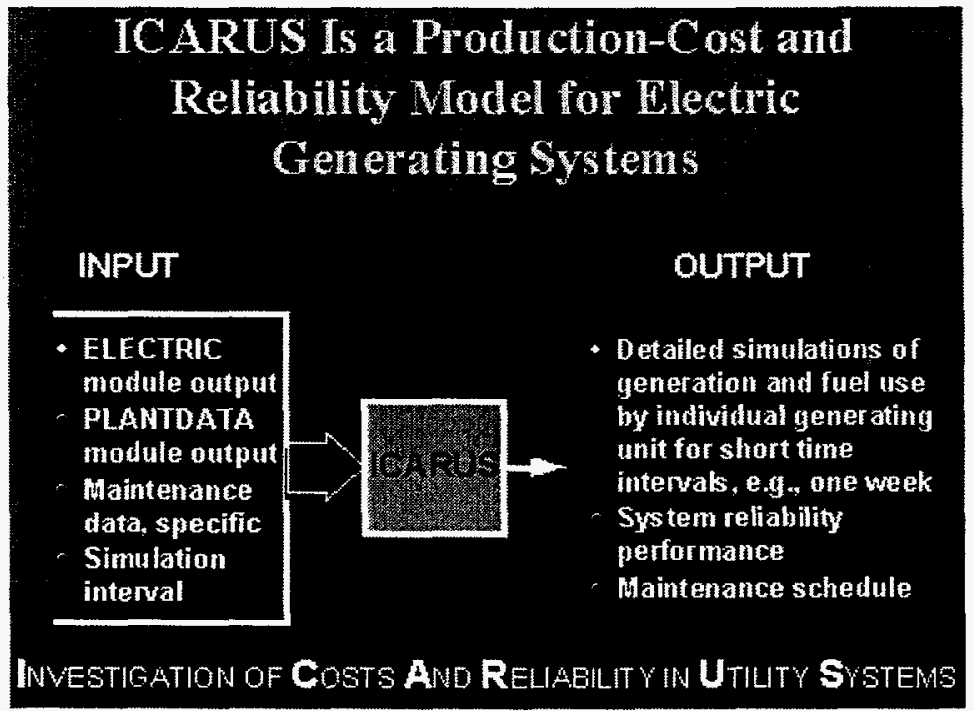

The module for Investigating Costs and Reliability in Utility Systems (ICARUS) of the ENPEP system can be used by the energy planner to analyze the detailed unit level operation of the electric generating system. ICARUS is a production-cost model with an efficient probabilistic simulation algorythm that calculates production costs and capacity factors for up to 600 unique plants and system-wide reliability for time periods of one week to one year. In addition, ICARUS is capable of simulating firm purchases and sales, emergency interties, and one energy-limited unit. In carrying out its analysis, ICARUS performs four major functions:

- Calculates the system loading order

- Calculates system maintenance schedule

- Calculates expected energy generation and costs

- Calculates system reliability parameters

ICARUS data requirements fall into three major categories: load data, unit data and economic data. The data inputs can be retrieved from an existing ELECTRIC analysis or manually entered into the ENPEP system.

For more information send an e-mail to enpep@anl.gov 


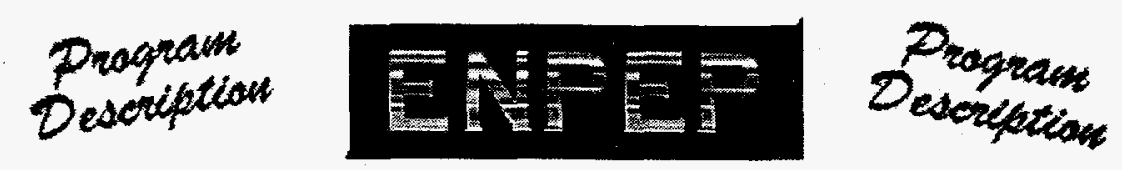

\section{IMPACTS Module}

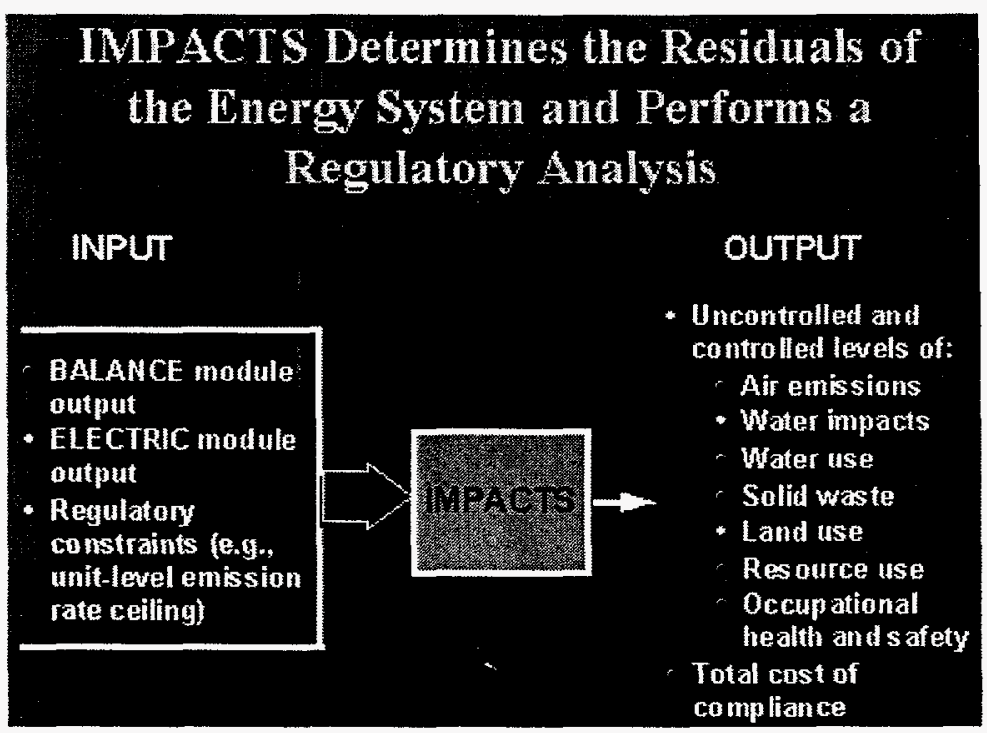

Once an energy system configuration has been designed, the environmental impacts and resource requirements of that configuration must be evaluated. Frequently, an energy system that is designed solely from the energy supply perspective cannot be implemented because of environmental constraints or resource limitations. The IMPACTS module is designed to estimate these effects.

The approach used in the ENPEP system is to develop an energy system configuration based on technical and economic considerations, then to determine the impacts. An iteration on the configuration may be necessary if the impacts prove to be unacceptable. Some modeling approaches attempt to do the technical, economic, and impact analyses simultaneously so as to arrive at the "best" energy system. A typical approach is to develop an objective function that incorporates all of these factors. In practice, the solution generated in this manner is frequently not implementable. The objective function, for example, may allow for tradeoffs between environmental quality and system performance whereas the real situation may not. Experience has shown that the iterative design process used in ENPEP is closer to actual conditions.

Facilities from both energy supply systems and energy end use sectors can be included in the IMPACTS analysis. For example, coal mines, power plants, refineries, and natural gas pipelines may be included as the supply part of this sector. Industrial boilers, residential space heaters, and automobiles may be included as part of the end use sectors. IMPACTS will determine the impacts of all these types of facilities.

For more information send an e-mail to enpep@anl.gov 

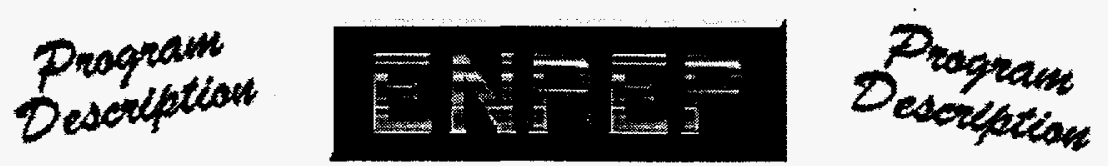

\section{Basis for Release}

The ENergy and Power Evaluation Program (ENPEP) computer package was developed by Argonne National Laboratory (ANL), under sponsorship of the United States Department of Energy (DOE), for the International Atomic Energy Agency (IAEA). The ENPEP computer package is released to IAEA's Member States and International Organizations on acceptance of special terms and conditions.

1. The ENPEP computer package is not to be sold or used to provide services for a fee by the Member State (including citizens of or organizations within such Member State) or International Organization to which the computer package is made available;

2. The ENPEP computer package is not to be released to another State (including citizens of or organizations within another State) or International Organization without the advanced written approval of IAEA;

3. The Member State or International Organization acknowledges that the DOE, ANL and IAEA make no claims regarding the usefulness of the ENPEP computer package and assume no liability arising from its use for any purpose;

4. The Member State or International Organization will inform IAEA of any innovations or improvements made to the ENPEP computer package and make these available to IAEA;

5. The Member State or International Organization shall designate an institution or senior person with whom the IAEA could correspond directly on matters concerned with the ENPEP computer package and who would inform IAEA of any innovations or improvements made to the package and arrange to make these available to IAEA;

6. The IAEA reserves the right to charge for any out-of-pocket costs, such as computer or delivery charges, which IAEA may incur in making the ENPEP computer package available to the Member State or International Organization, on the same basis that the IAEA would normally request reimbursement if any other computer program were involved. Before proceeding with any work involving such out-of-pocket costs, the IAEA will advise the Member State or Organization and obtain their agreement in advance;

7. The Member State may authorize its "national" (or "principal") Liaison Officer to release the ENPEP computer package to research institutes, universities and other non-commercial institutions and organizations within the country under the same terms and conditions set out above. The "national" (or "principal") Liaison Officer so authorized is responsible to ensure that such a recipient institution or organization acknowledges and accepts in writing the above terms and conditions and also nominates a senior staff member as Liaison Officer responsible for maintaining liaison with the "national" (or "principal") Liaison Officer. 


\section{Recent ENPEP Applications}

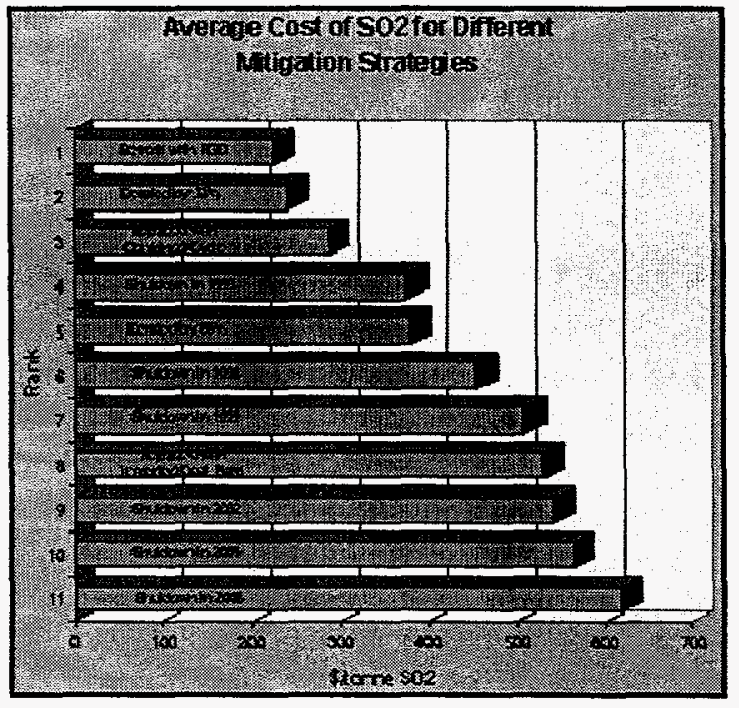

Click picture to view full size image. (22k)

\section{Evaluating Hydroelectric Power Projects in Nepal}

- Objective: Analyze the least-cost expansion plan for Nepal's hydro-dominated electric generating system under various assumptions.

- Conclusion: Hydro Power is an important part of the least-cost expansion plan; Nepal's imported fuel bill will depend strongly on when new hydro plants are added.

\section{Determining the Most Cost-Effective $\mathrm{SO} 2$} Control Strategy in Southwestern Turkey

- Objective: Evaluate power sector options for reducing $\mathrm{SO} 2$ emissions from an existing lignite-fired power plant, including shutdown and replacement.

- Conclusion: Retrofit the plant with wet FGD is the most cost-effective option available.

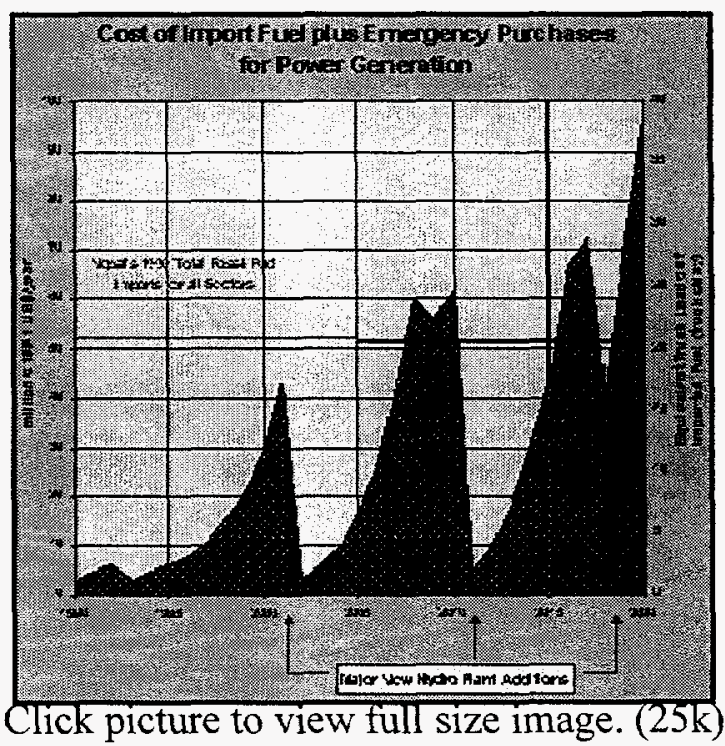




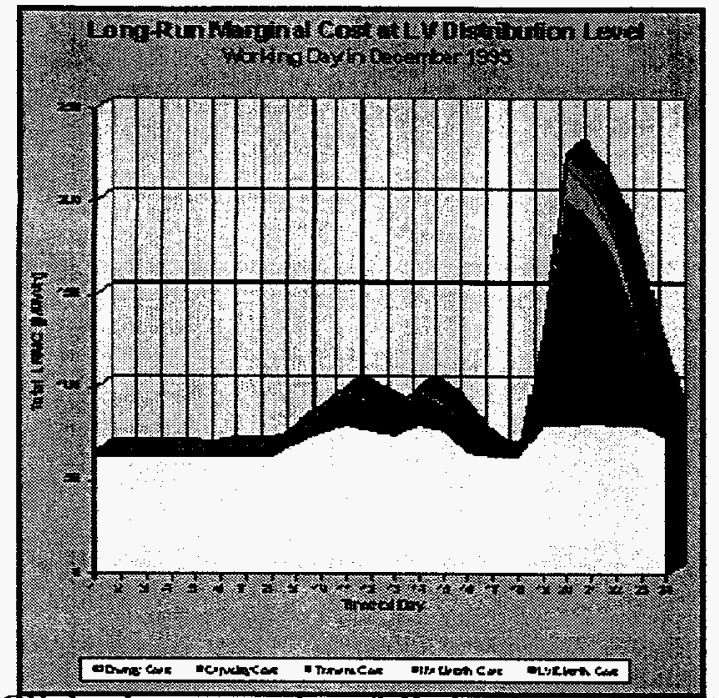

\section{Developing a Sound Tariff Structure for the Guyana Electricity Corporation}

- Objective: Determine the long-run marginal cost of electricity generation for customers at different voltage levels and different time periods during the year.

- Conclusion: An efficient tariff system can be developed that respects the consumption characteristics of each consumer group and ensures the financial viability of the utility.

\section{Analyzing Greenhouse Gas Mitigation Options for the U.S.}

- Objective: Evaluate the effectiveness of alternative measures to offset $\mathrm{CO} 2$ emissions from new major sources in the U.S.

- Conclusion: Implementing demand-side options (in residential, transportation sectors) will not offset new $\mathrm{CO} 2$ emission sources. Major changes in electric power generation will need to be implemented to meet the offset requirements

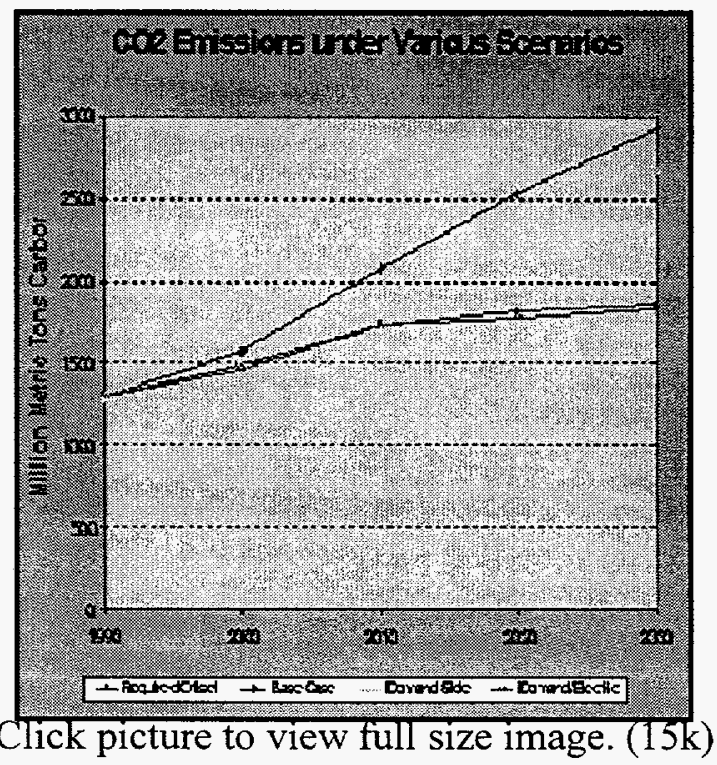

For more information send an e-mail to enpep@anl.gov 

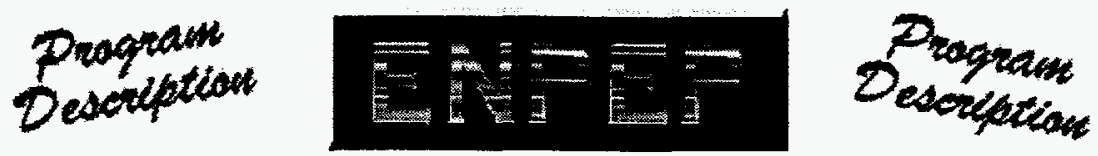

\section{Other software}

\section{DECPAC}

DECPAC is a software tool which provides a user-oriented interface for utilizing the information stored in the DECADES project databases to analyze technical, economic and environmental aspects of different energy sources for electricity generation. The model provides several levels of analysis (power plant, fuel chain, and electric power system) to support and facilitate comparative assessment studies. At the system level, DECPAC integrates electric system expansion planning with the analysis of primary energy supply chains, and computes the resulting environmental emissions. The DECADES databases are integrated in a Data Management System, developed by the IAEA using the commercial software "Paradox for Windows" which runs on personal computers. The DECADES databases include the Reference Technology Data Base (RTDB), and more than 15 Country Specific Data Bases (CSDB). Future areas for DECPAC development include the assessment of environmental impacts and damages, analysis of environmental regulations, and multi-criteria decision analysis.

\section{WasteSIMS}

WasteSIMS, a Windows-based client/server Geographical Information System (GIS), is an interactive modeling tool designed to assist in hazardous waste processing by analyzing the costs and risks of waste treatment, storage, and disposal. Specifically, the system is designed to quantitatively describe the risks, possible health effects and costs of different waste processing alternatives. The quantitative results are based on a wide variety of factors, including the chemical composition of the waste, the radionuclides present in the waste, the short-term contaminant dose-response of individuals, the long-term contaminant dose-response of populations, the costs of processing facilities, the costs of waste transportation, and the geographical configurations of the waste processing alternatives. The WasteSIMS model is composed of a client/server GIS interface connected to the independent cost and risk models.

\section{VALORAGUA}

VALORAGUA is a model which main objective is to determine the optimal generating strategy of mixed hydro-thermal electric power systems. The optimal operation strategy is obtained for the system as a whole, with emphasis on the detailed simulation and optimization of the hydro subsystem operation. The model can simulate the operation of all types of hydropower plants (run-of-river, weekly, monthly, seasonal or multi-annual regulation) including pumped-storage plants and multi-purpose hydro projects. The VALORAGUA model calculates possible production of hydropower plants based on a historical series of monthly water inflows or on the basis of synthetic water inflows with associated probabilities of occurrence. The model works with the hydraulic network of the country (or region) and is capable of determining the optimal operation of up to 18 hydro-cascades in the system. The most outstanding feature of the VALORAGUA model is the calculation of the marginal value of water in the reservoirs. The model calculates the value of water in all periods of the year by taking into account the system load and the availability of thermal production in each period. The mathematical expectancy of the future value of water is the basis for making decisions whether to use the water from the reservoirs now or retain it for later use. 


\section{Spot Market Network Model (SMN)}

The Spot Market Network (SMN) Model is a multi-purpose tool that can be used for a wide range of applications. At a relatively high level of aggregation (e.g., company level), the model determines the level of economic energy transactions between utility companies such that overall costs are minimized. At a finer level of detail (e.g., unit level), SMN determines the optimal dispatch of units while considering unit-level operational restrictions and transmission limitations. An SMN network, which is designed and created by a power systems analyst, consists of a set of nodes and links. Nodes in the network represent generating resources and load centers. Generating resources are represented as piece-wise linear marginal cost curves, while load centers are represented by estimates of hourly electricity demand. Nodes are connected via links representing transmission lines with limitations and line losses for power flows between nodes. The model minimizes production costs subject to the utility-specific minimum profit margins that trigger spot market transactions. SMN also recognizes line rights and includes wheeling, sales-for-resale transactions, and line usage reserved for long-term firm transactions. Inadvertent power flows can be factored into the simulation by adjusting line capacities in one or both directions or by using power transfer distribution factors (TDF) derived from power flow models.

\section{Hydro Dispatch Model}

The Hydro Dispath Model is a Linear Program (LP) that simulates the hourly operations of an integrated system of hydropower plants. It maximizes net revenues for spot market purchases and sales, subject to hourly firm load commitments and institutional and operational constraints. The Hydro Model also solves for hourly generation, purchases made under firm contracts, and spot market activities. Spot market activities are based on market prices or short-run marginal costs, hydropower operational flexibility, the amount of water available for generation, hourly firm commitments, project use loads, area load control commitments, spinning reserve requirements, and firm purchasing programs. The operational restrictions incorporated into the Hydro Model include: (1) minimum and maximum flow restrictions, (2) hourly and daily ramp rate restrictions, and (3) minimum and maximum reservoir water elevations. The model also includes a profit margin requirement for off-peak to on-peak hydropower shifting.

\section{Stochastic Analysis of Technology Systems (STATS)}

The STATS model was originally developed to estimate composite uncertainty distributions for various systems and technologies. STATS provides a convenient approach for treating uncertainties and correlations between cost and performance components. The approach has the capacity to provide improvements in comparisons based simply on combinations of best point estimates. The additional information developed in uncertainty analysis is useful for considering relative risks and benefits of technology or system expansion options.

\section{Argonne Utility Simulation Model (ARGUS)}

The ARGUS model accounts for the interplay of economic, environmental, and technology factors in energy policy issues and emission-control strategies. Each of the four components of ARGUS represents a specific aspect of the utility sector. One component deals with meeting future electricity demand through the construction of new generating units or refurbishing existing units. A second component dispatches units and computes electricity production costs and reliability. The third component projects air pollution emission levels and the cost of implementing air pollution control strategies. The fourth component projects the delivered price of coal based on volume of coal, supply region, and transportation route. All four model components are integrated and include feedback mechanisms. 


\section{Production and Capacity Expansion Model (PACE)}

The PACE model is a Dynamic Program (DP) that is used to determine long-term utility capacity expansion schedules. New unit additions are based on the makeup of existing supply resources, candidate technologies, load growth estimates, and long-term firm contracts. The model also expands system capacity such that reliability constraints are not violated. PACE employs ICARUS to estimate unit-level generation, production costs, and system loss-of-load probabilities for various possible capacity expansion paths. These costs, along with capital investment costs and fixed O\&M costs, are used by PACE to estimate the least-cost expansion path as well as suboptimal expansion paths.

For more information send an e-mail toenpep@anl.gov 


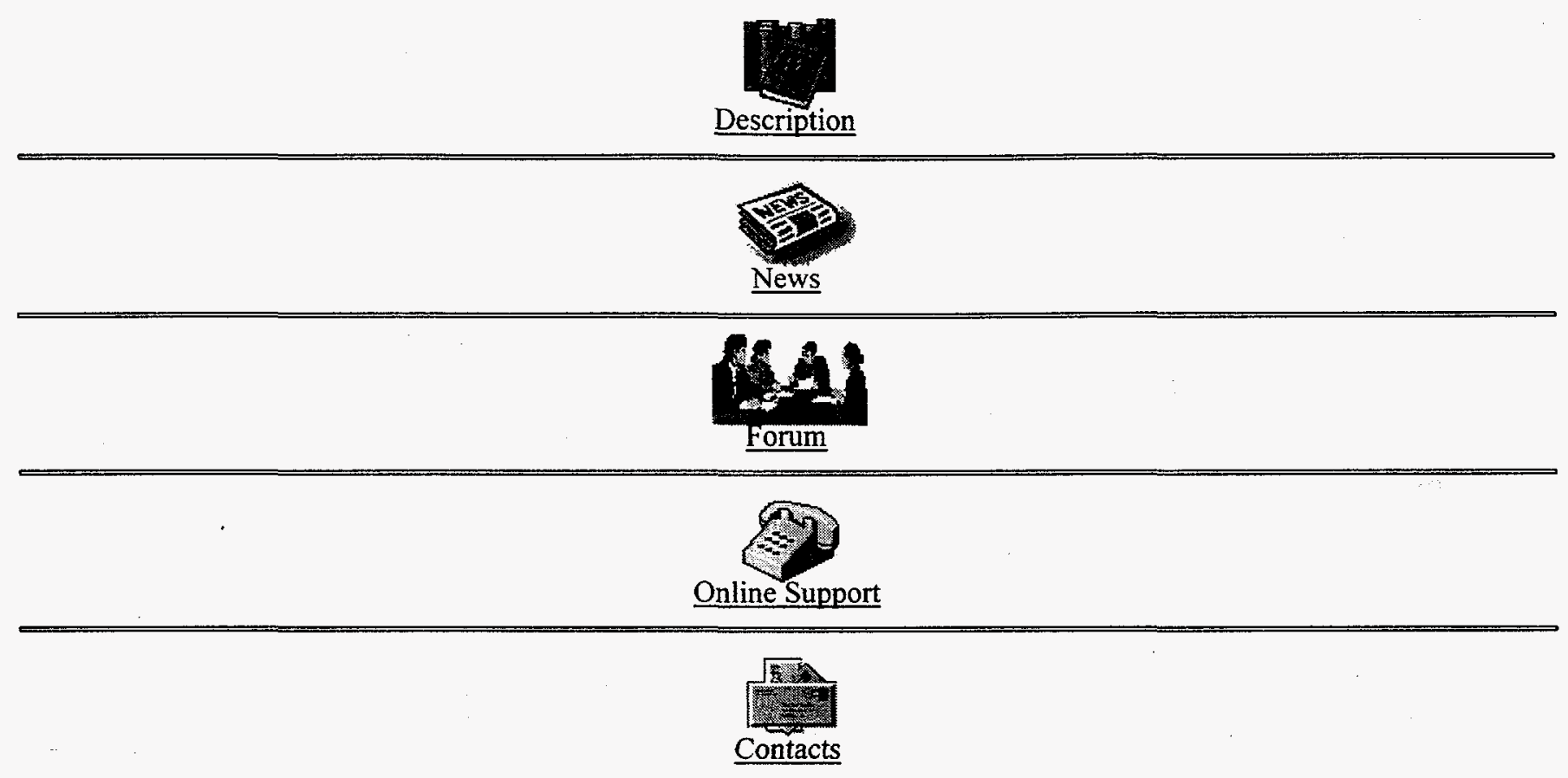




\section{Training Courses, Workshops and Seminars}

\begin{tabular}{|c|l|c|}
\hline \multicolumn{1}{|c|}{ Date } & \multicolumn{1}{|c|}{ Subject } & Location \\
\hline June 3rd-June 14th 1996 & $\begin{array}{l}\text { TCM/Workshop on the Use of } \\
\text { DECADES Computer Tools } \\
\text { (DECPAC). }\end{array}$ & Poland \\
\hline June 17th-July 26th 1996 & $\begin{array}{l}\text { IAEA Regional ENPEP Training } \\
\text { Course. }\end{array}$ & Thailand \\
\hline $\begin{array}{c}\text { 18th 1996 } \\
\text { 18tember 9th-October }\end{array}$ & $\begin{array}{l}\text { IAEA Interregional Training Course } \\
\text { on Electricity Demand Forecasting for } \\
\text { Nuclear Power Planning (MAED). }\end{array}$ & $\begin{array}{c}\text { Argonne, } \\
\text { Illinois, USA }\end{array}$ \\
\hline $\begin{array}{l}\text { November-December 1996 } \\
\text { NCM/Workshop on the Use of } \\
\text { DECADES Computer Tools } \\
\text { (DECPAC). }\end{array}$ & $\begin{array}{l}\text { Argonne, } \\
\text { Illinois, USA }\end{array}$ \\
\hline
\end{tabular}

For more information about which countries have participated in training courses at Argonne National Laboratory and a general description of training courses, either see our training map or send an e-mail to enpep@anl.gov. 


\section{Program Information}

\section{Instructions for Windows 95 Users}

\section{ENPEP Installation:}

Insert the ENPEP Installation disk into the 3.5" floppy drive (A:). Within the File Manager click on My Computer, select the 3.5" Floppy (A:) drive and double click on the INSTALL.BAT file. The regular installation process will be performed.

\section{Creating an ENPEP Icon:}

After installation of the ENPEP software go back to My Computer and click on the C: drive (or the corresponding drive on which the ENPEP model has been installed). Go to the ENPEP directory and click once on the ENPEP.BAT file. On the menu bar click on File and then select the Create Shortcut option. With the right mouse button click on the Shortcut to ENPEP.BAT icon, which was just created. Choose the Properties option from the list. From the options in ENPEP.BAT properties choose Screen and for the usage option it is suggested to use Window. Click the Apply button and then the OK button. To change the icon name from Shortcut to ENPEP.BAT to just ENPEP, click on the icon name and overwrite the existing text. Finally, drag the ENPEP icon onto your background for easy access.

\section{Running ENPEP:}

Double click on the ENPEP icon and run the program within the ENPEP window.

For more information send an e-mail to enpep@anl.gov 


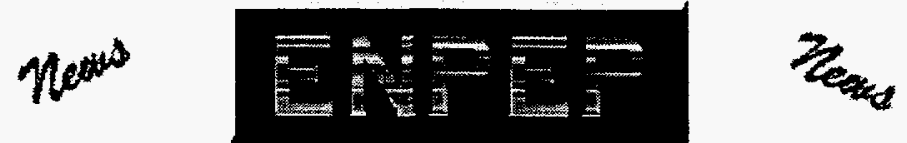

\section{Program Updates}

\section{SUMMARY OF ENHANCEMENTS INTRODUCED IN THE CURRENT VERSION OF ENPEP}

\author{
(VERSION 3.0, MAY 1996)
}

\section{INTRODUCTION}

The ENergy and Power Evaluation Program (ENPEP) package was originally developed by Argonne National Laboratory (ANL) under funding provided by the U.S. Department of Energy (USDOE). Under a special agreement, the package was released to the IAEA for further transfer to interested Member States and international organizations following a standard release procedure.

Since 1989, ENPEP has served as the basis for several interrelated activities. Training on the use of the package has been provided at training courses organized by the IAEA at interregional and regional levels under the regular Training Program of the Agency. Similar training was arranged by the United Nations Development Program (UNDP) and the World bank (IBRD) under the Regional Project for Energy Planning for European and Arab States. At the end of each training course, participating countries have been provided with a copy of the programs. In addition, ENPEP has been used to conduct planning studies organized as part of the UNDP/IBRD regional project above mentioned and the regular Technical Co-operation Program of the IAEA.

Along with these applications of ENPEP, several enhancements have been introduced into the programs in order to respond to requirements by the various users, to remove bugs encountered in the programs, and to adapt the programs to changing environment regarding computer hardware and software developments. These activities have been supported by the UNDP/IBRD project above mentioned and the IAEA, with partial funding by USDOE.

The complete list of enhancements introduced into the program since it was first developed would be too long and in some cases pointless. Therefore, this document concentrates on the chronology of enhancements between several important dates when bulk distribution of the program was made, i.e., at the end of a training event or during the conduct of the national case studies mentioned above. It is expected that this list will allow ENPEP recipients to recognize which enhancements have been introduced in the current version of the program with respect to the version that is available to them. The enhancements are chronologically divided into the following periods:

1. Enhancements introduced between September 1992 and August 1994;

2. Enhancements introduced between August 1994 and September 1995;

3. Enhancements introduced between September 1995 and May 1996.

These are detailed in the following paragraphs. Also, because of the importance of the BALANCE module, Section $\mathrm{V}$ shows the dimensions of the several parameters used by this program with a breakdown for the various periods listed above.

\section{ENPEP ENHANCEMENTS BETWEEN SEPTEMBER 1992 AND AUGUST 1994}




\section{GENERAL:}

- Screens modified so that all modules adhere to a standard format. Main screen changes were made in MAED, LDC, and ICARUS modules.

- A new version of ENPEP User's Manual was prepared to reflect changes in programs and screens.

\section{PLANTDATA:}

- Transfer program from PLANTDATA to ELECTRIC updated to handle increased limits of WASP-III Plus.

\section{BALANCE:}

- Increased program dimensions (see the table below):

- Depletable resources: from 30 to 75

o Conversion nodes: from 135 to 300

- Decision nodes: from 100 to 200

- A modification was introduced to allow the user to specify an optional loading order value for thermal and hydro units in the electric sector.

\section{ELECTRIC:}

- ELECTRIC was completely modified to adapt it to the newest version of WASP (WASP-III Plus). The menus were modified accordingly. However, the data transfer from the new ELECTRIC module to IMPACTS was not implemented.

\section{ENPEP ENHANCEMENTS BETWEEN AUGUST 1994 AND SEPTEMBER 1995}

\section{BALANCE:}

- An option to use an editor, in addition to the paging routine, was introduced for viewing the output files.

\section{IMPACTS:}

- Screen 1490B was modified in order to remove the use of the "F7" function key to copy a generic facility. This option was corrupting the Generic Energy Data Base.

\section{ENPEP ENHANCEMENTS BETWEEN SEPTEMBER 1995 AND MAY 1996}

\section{ALL MODULES:}

- A new version of the ENPEP User's Manual was prepared in order to reflect changes in the programs and screens.

\section{DATA TRANSFERS:}

- Interfaces for data transfers between all ENPEP modules were tested, certain problems found were corrected, and the links with the ELECTRIC module (after the implementation of the WASP-III+ model) were re-established.

\section{EXECUTIVE:}

- A routine was introduced to check if the ENPEP model is installed on the current disk drive.

\section{PLANTDATA:}

- A problem causing the "case not found" error when exporting data from a PLANTDATA case with case number higher than 99 to BALANCE, ELECTRIC and ICARUS was corrected.

\section{BALANCE:}

- The problem of capital cost of a refinery process that becomes available several years after the base year of the study was corrected by adding the calculation function into the INPUT 
FORTRAN subroutine;

- The number of depletable resources was increased from 30 to 75 by changing the dimension of the related array in all FORTRAN subroutines. Problems associated with depletable node data "overwriting" the renewable node data were also corrected;

- The problem of the "lag" parameter treated incorrectly for the nodes with no possibility for fuel substitutions is corrected by adding one temporary array into the common data block and changing the related calculation method in the FORTRAN code;

- The UP/DOWN pass routine was modified to accommodate 1,000 links and the BASIC routine for viewing the UP/DOWN pass node call sequences was enhanced to permit viewing of up to 1,000 node sequences;

- An UP pass process is added to the simulation after the convergence has been reached to update the final prices;

- Screen B051 was modified to allow the user to view up to 60 special events (there is no limit on the number of special events in BALANCE that can be specified using an editor);

- For the electric generating units, the derated capacity due to the maintenance schedule is now calculated correctly;

- Indexing problems associated with unit conversions for electric generation were corrected;

- The number of demand nodes has been increased from 100 to 200. The change affected program B027.BAS and screen B027.SCN;

- The ALCHECK post-processor routine has been introduced into the BALANCE FORTRAN code to check the resulting balances in the allocation and multiple output nodes. The routine is executed automatically at the end of a BALANCE run and writes a report into the TIME.OUT file. No new screens associated with the ALCHECK subroutine were introduced into the BALANCE module;

- A problem related to the calculation of capital costs for staged investments into conversion processes was corrected;

- ENPEPTRF.EXE program is now included in the BALANCE distribution disk and, after installation, will be located in the $\backslash$ BALANCE directory. This program was developed by Ms. M. Guedelha, Ministry of Energy of Portugal and serves to import the BALANCE output into a spreadsheet program (EXCEL MS*);

- Several screen display errors have been corrected. The modified screens are B024, B025, $\mathrm{B} 033, \mathrm{~B} 034, \mathrm{~B} 051, \mathrm{~B} 052$, and B088.

\section{ELECTRIC:}

- The interface for data transfer to IMPACTS is now re-established. The ELIM1 and ELIM2 files are created by the REPROBAT module, while the ELIM3 file is created during the REMERSIM run;

- The size of the data entry routine in the LOADSY module was reduced from $487 \mathrm{~K}$ to $456 \mathrm{~K}$.

- The file hadling in MERSIM and REPROBAT modules was modified to avoid the ocurrence of the "Too many files open" problem;

- The warning messages in the DYNPRO module, which stated that fuel price multipliers and escalation factors specified in the input data file as 0.0 or blank would be automatically reset to 1.0 by the program, were commented out and will not appear in the output;

- The problem causing an error in the status of the LOADSY module, after the data transfer from LDC, was corrected. This involved modifications in E500.BAS (saving the COMMON.DAT file) and E004.BAS;

- The number of fuel types in VAR.BAS was changed from 5 to 10 to match the number of fuel types in WASP III Plus;

- Typo errors were corrected as follows:

- In screen E021.SCN, the text "can represented" was replaced with "can be represented";

- In screen E089.SCN, the text "Selecting an BALANCE case" was replaced with "Selecting a BALANCE case";

- In screen E203.SCN, the text "Distibution of Construction" was replaced with "Distribution of Construction";

\section{MAED:}

- The number of characters for the "planning study" name was increased from 7 to 8 in the 
screens Z050.SCN and Z400.SCN;

- The redundant error messages in the programs Z215.BAS and Z215EXT.BAS were removed;

- An initialization problem causing a return to system in programs Z400.BAS and Z600.BAS was corrected;

- In the screen Z010.SCN, a blank line was added between the two options, in order to make this screen look like the opening screens in other modules of ENPEP;

\section{ICARUS:}

- For the data transfer from the PLANTDATA module, a routine was added to check if the generating units are represented with one or two blocks, in order to avoid writing unnecessary data in the UNITDATA file.

- In the routine for data transfer from PLANTDATA, a unit conversion factor $(\mathrm{kcal} / \mathrm{kWh}$ to $\mathrm{Btu} / \mathrm{kWh}$ ) for the second block heat rate was corrected from 3.79 to 3.97 .

\section{IMPACTS:}

- The option 5 in the screen I003A: "Retrieve data from an external file" was removed;

- Certain file handling problems in the program I210.BAS were corrected;

- The word "Electric" was replaced with the word "Option" in the screen I210;

- The problem associated with the option number 7 for viewing IMPACTS results has been corrected;

- The routine that imports data from BALANCE was enhanced to handle the cases with up to 75-year long study period (to match the BALANCE maximum). However, the RAM memory requirements also increase with the number of years contained in the case. The maximum requirement is $610 \mathrm{~K}$ of available RAM memory for 75 years. Cases with fewer number of years would require less RAM memory to perform the data transfer from BALANCE to IMPACTS.

\section{DIMENSIONS OF THE BALANCE PROGRAM}

- The chronological evolution of the dimensions of the most important variables of the BALANCE module are summarized in the following table. 


\begin{tabular}{|l|c|c|c|c||}
\hline \multicolumn{1}{|c|}{ ITEM } & Origina & $\mathbf{1 9 9 2}$ & $\mathbf{1 9 9 4}$ & $\mathbf{1 9 9 6}$ \\
\hline Depletable Resources & 30 & 30 & 75 & $\mathbf{7 5}$ \\
\hline Depletable Resource Price Projection & 30 & 30 & 30 & 30 \\
\hline Renewable Resources & 17 & 17 & 17 & 17 \\
\hline Conversion Nodes & 135 & 135 & 300 & 300 \\
\hline Multiple Output Facilities & 10 & 30 & 30 & 30 \\
\hline Stockpiling & 20 & 20 & 20 & 20 \\
\hline Multiple Input Facilities & 15 & 15 & 15 & 15 \\
\hline Decision Nodes & 100 & 100 & 200 & 200 \\
\hline Pricing Nodes & 40 & 100 & 100 & 100 \\
\hline \hline Demand Nodes & 60 & 100 & 100 & 200 \\
\hline Demand Growth Projection Sets & 30 & 30 & 30 & 100 \\
\hline Capacitated Links & 96 & 96 & 96 & 96 \\
\hline Special Events (shown on screen) & 40 & 40 & 40 & 60 \\
\hline Thermal Units in Electric Sector & 300 & 300 & 300 & 300 \\
\hline Hydro Projects in Electric Sector & 300 & 300 & 300 & 300 \\
\hline Thermal Unit Conversions & 135 & 135 & 135 & 135 \\
\hline Total Number of Network Links & 500 & 500 & 500 & 1000 \\
\hline Maximum Number of Years in Study & 30 & 75 & 75 & 75 \\
\hline
\end{tabular}




\section{Post a Message in our Forum}

Enter your name:

Enter your e-mail address:

Enter your home page address:

City: , State: Country: Enter a subject:

Select a module:

\begin{tabular}{|l|l|}
\hline$A I I$ &
\end{tabular}

Type in your comment or question:

4

Post $] *$ Reset




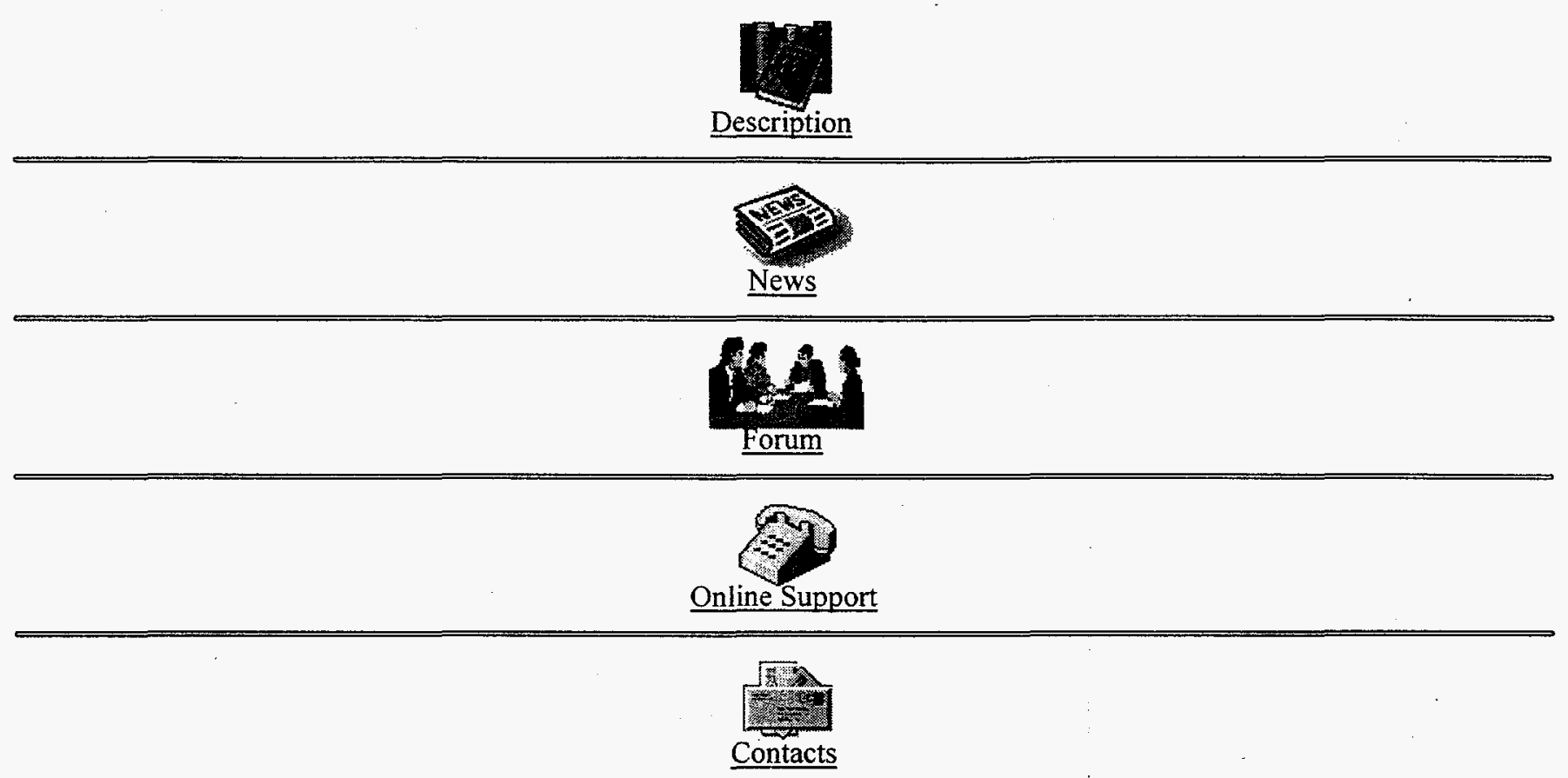




\section{$\infty$
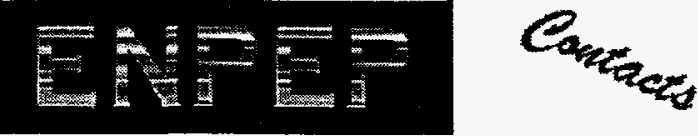

\section{Training Courses in Energy Planning:}

\section{Countries having participated in Argonne's training courses are in green.}

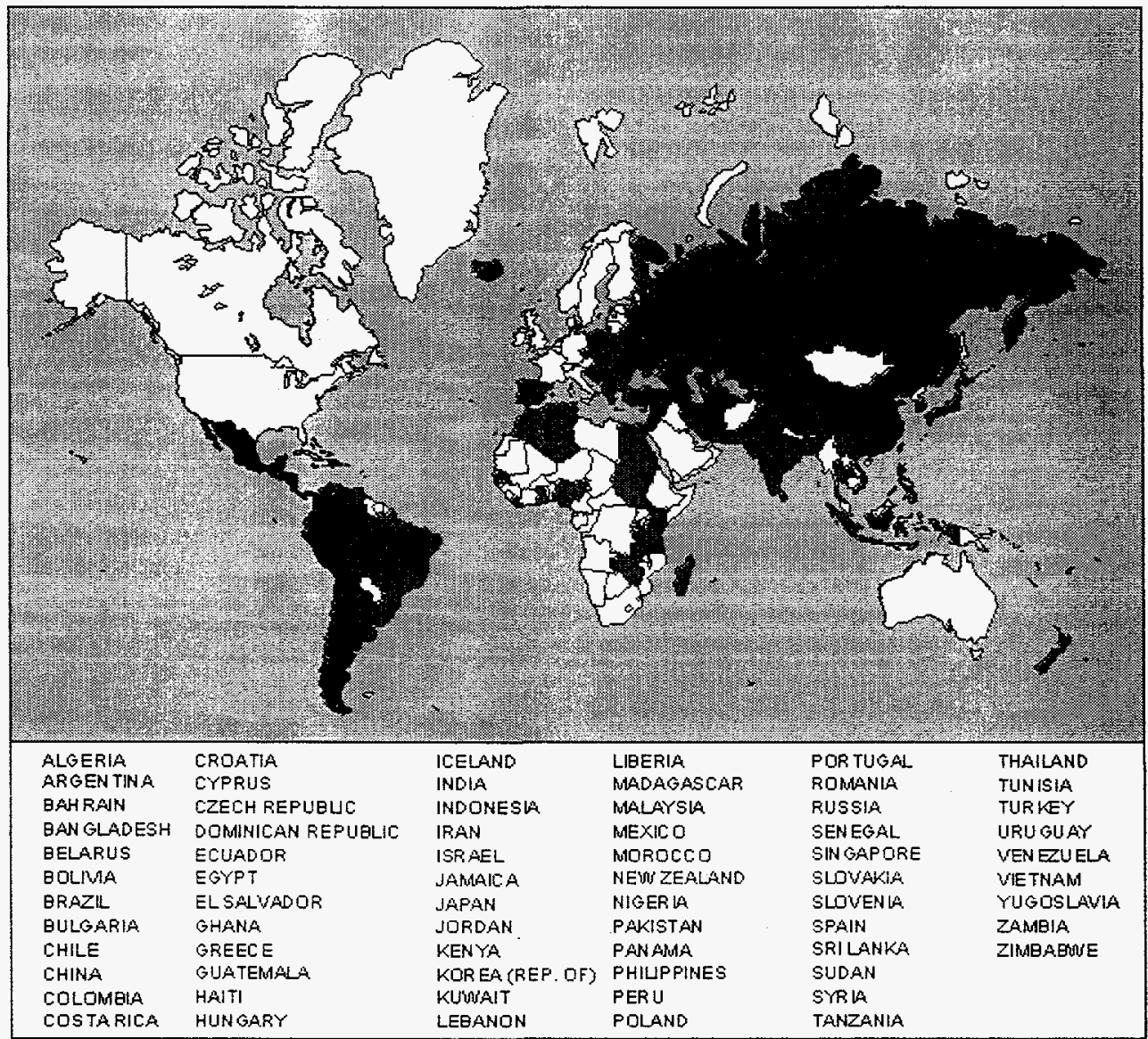

Since 1978, Argonne has been leading five- to eight-week-long training courses in electricity demand forecasting, electric system expansion planning, total energy system analysis and energy/environmental analysis. Training courses have been organized and conducted by Argonne (ANL) experts from the Decision and Information Sciences (DIS) division and the Division of Educational Programs (DEP). Funding is provided by the International Atomic Energy Agency (IAEA), the Department of Energy (DOE), and the Department of State (DOS). Certain training courses are sponsored by the World Bank, The goal is to transfer planning methods to the developing countries so that local staff can continue the planning process for their countries with minimal outside assistance.

Argonne has conducted more than 20 training courses for energy and environmental analysis from 68 countries (see the map). The current training courses focus on key components of the ENPEP software. Most courses are conducted at Argonne's facility which is about 25 miles southwest of Chicago, Illinois. Additionally, Argonne staff have participated in in-country training courses in places such as China, Pakistan, Malaysia, Hungary, and Thailand.

After attending the main training course, planners can return to Argonne for additional work with Argonne specialists. Argonne researchers also travel to the countries to provide additional technical 
support to the in-country energy planning team after planners participate in one of the standard training courses.

For more information send an e-mail to enpep@anl.gov 
- Knunos e uo צว!เ
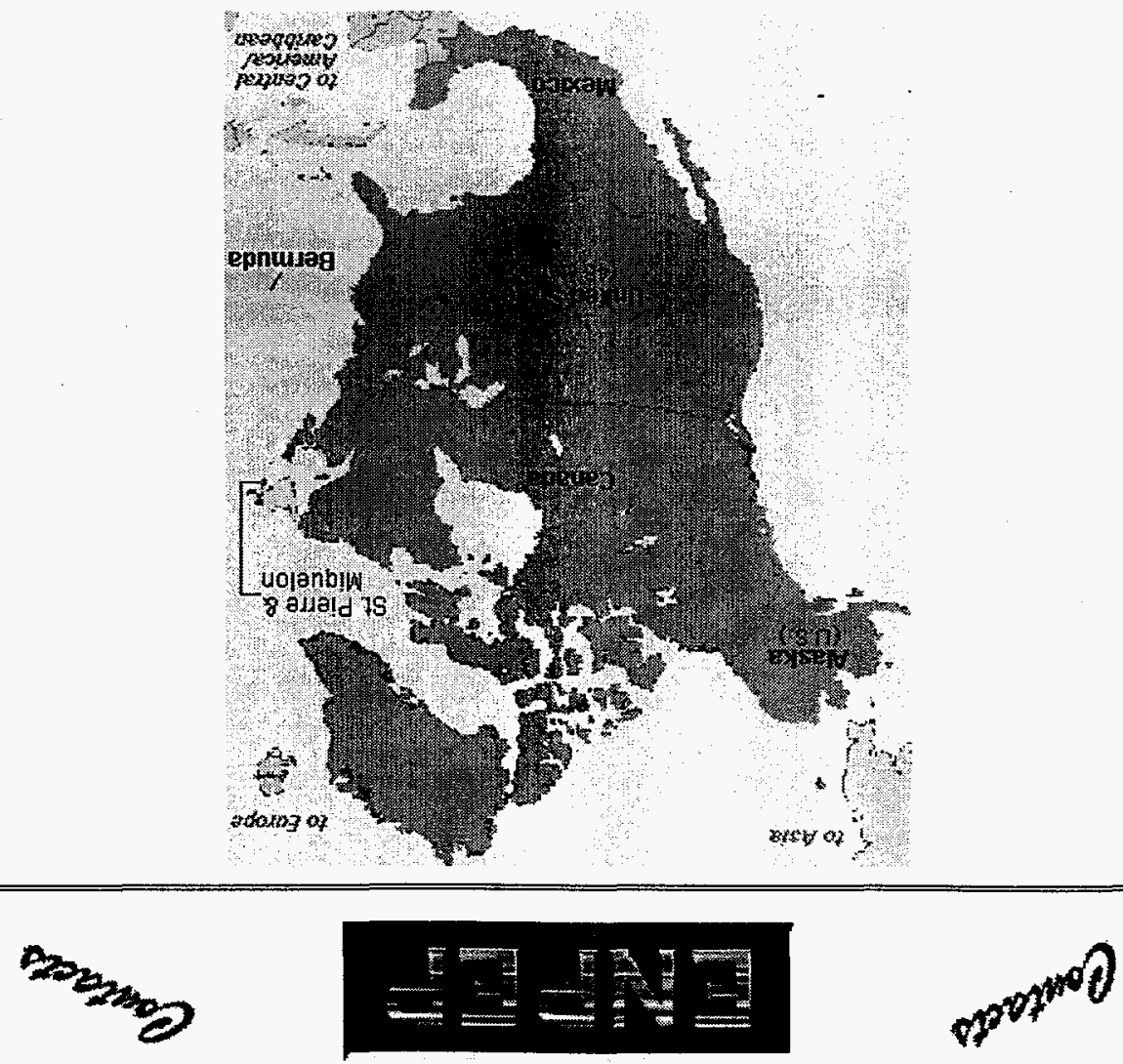

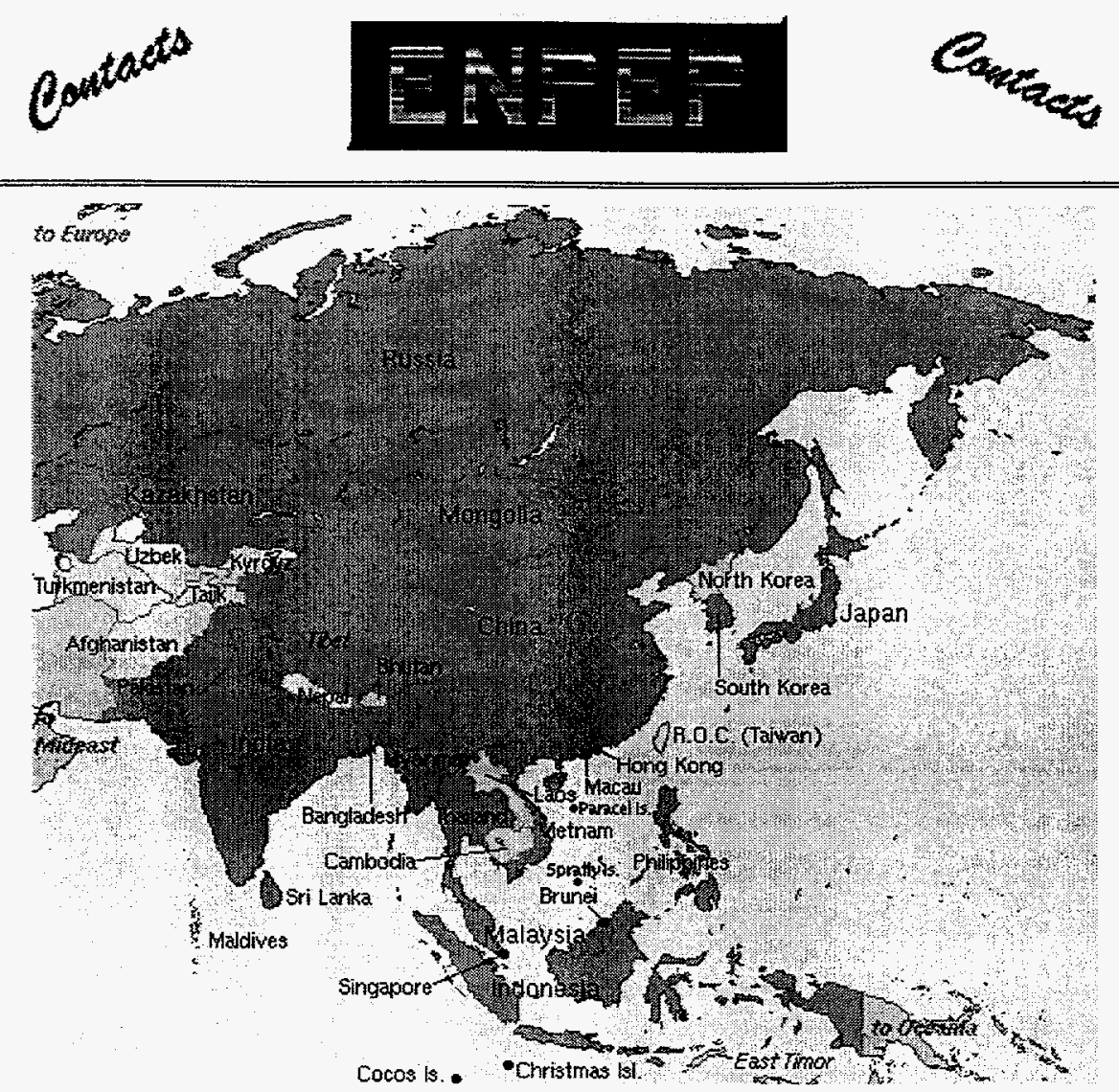

Click on a country. 


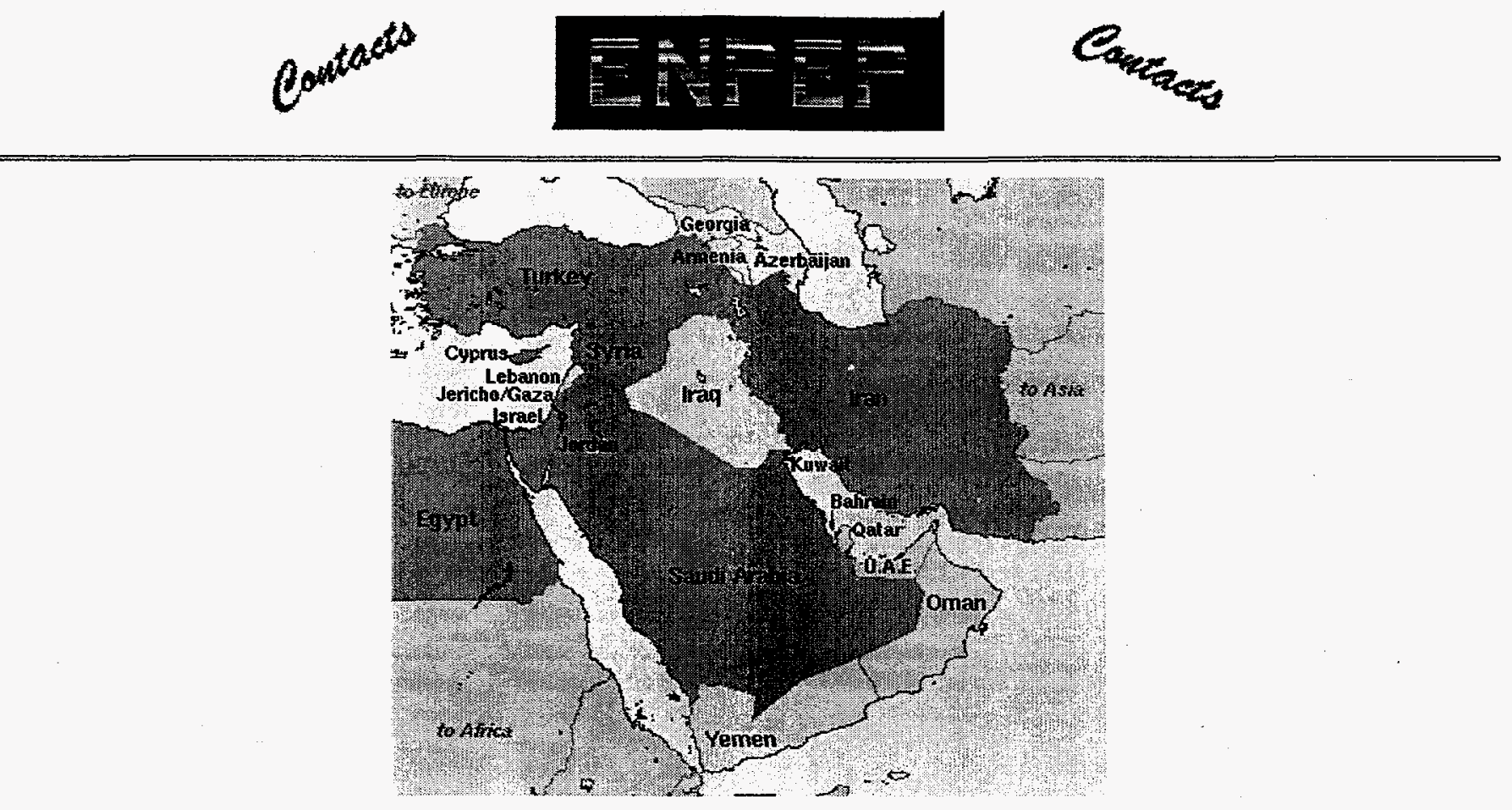

Click on a country. 

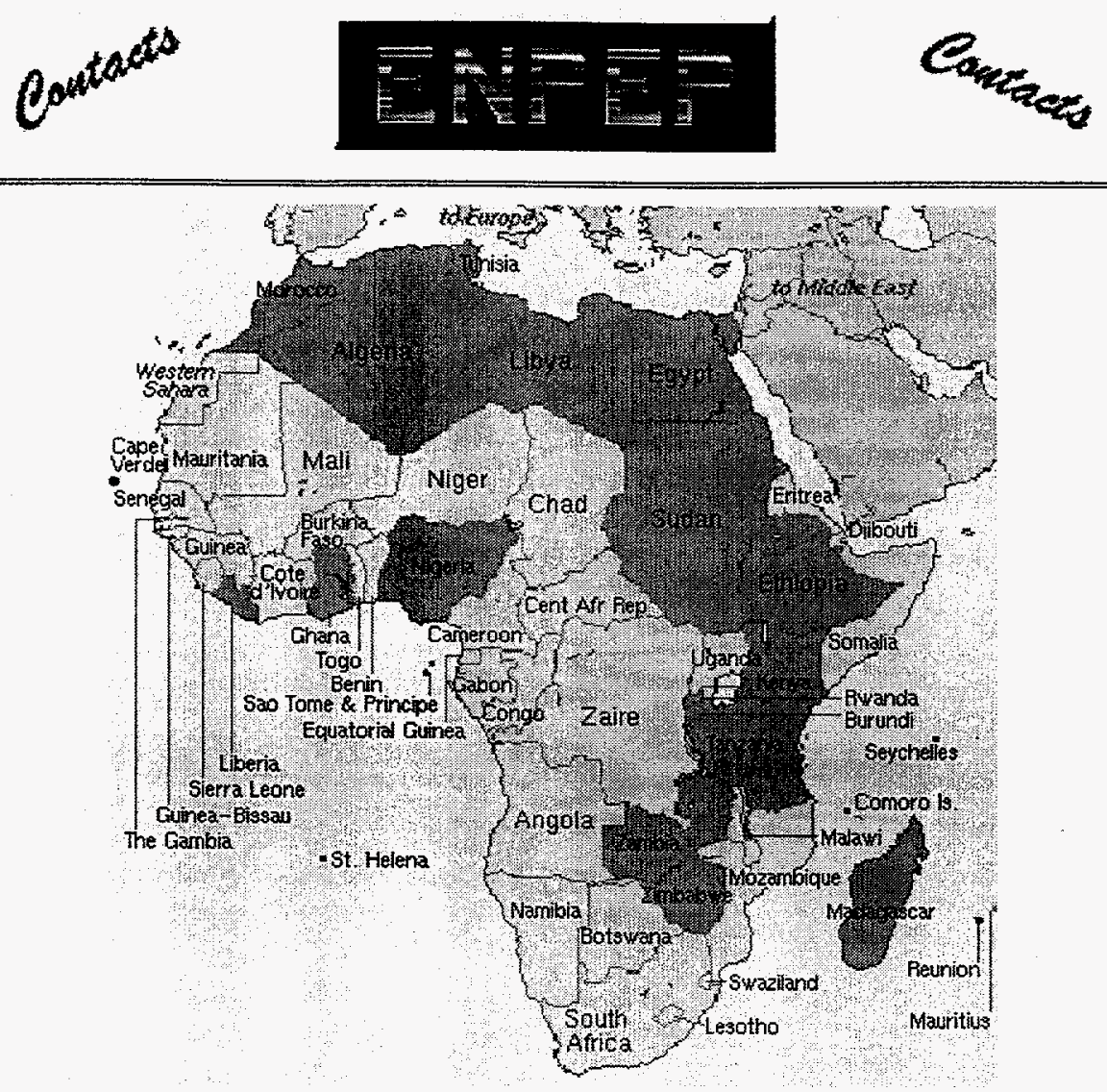

Click on a country. 


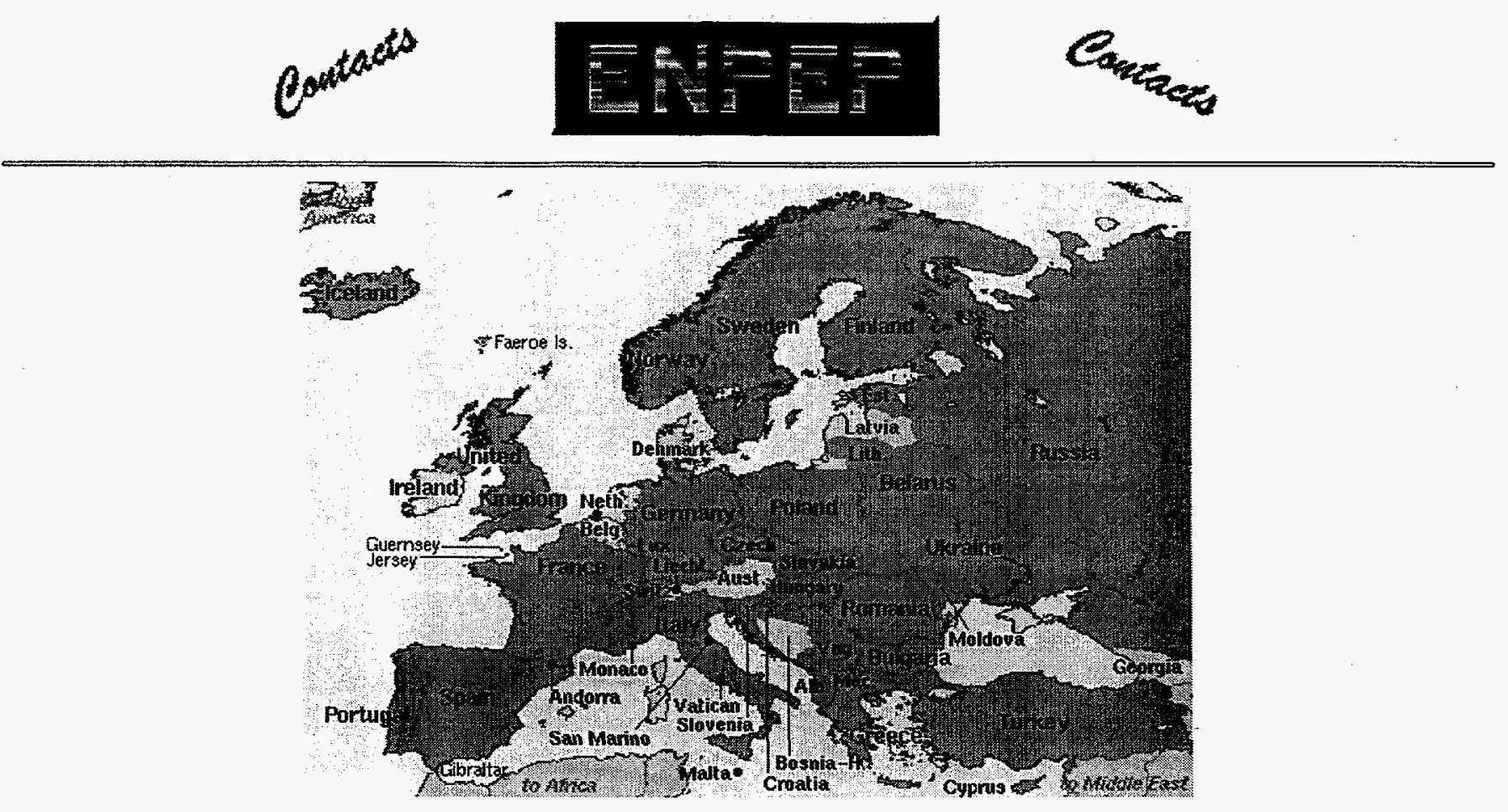

Click on a country. 


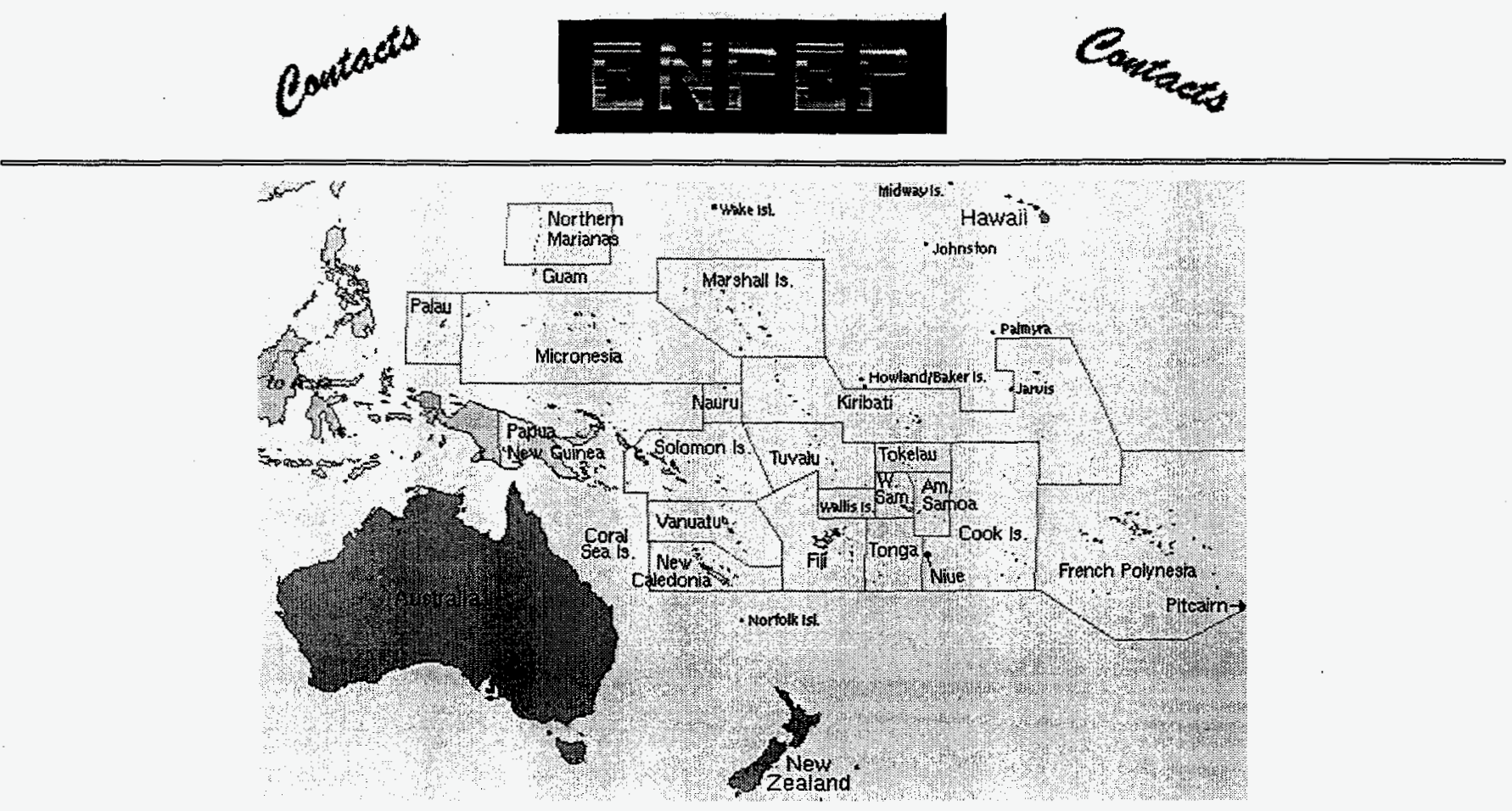

Click on a country. 

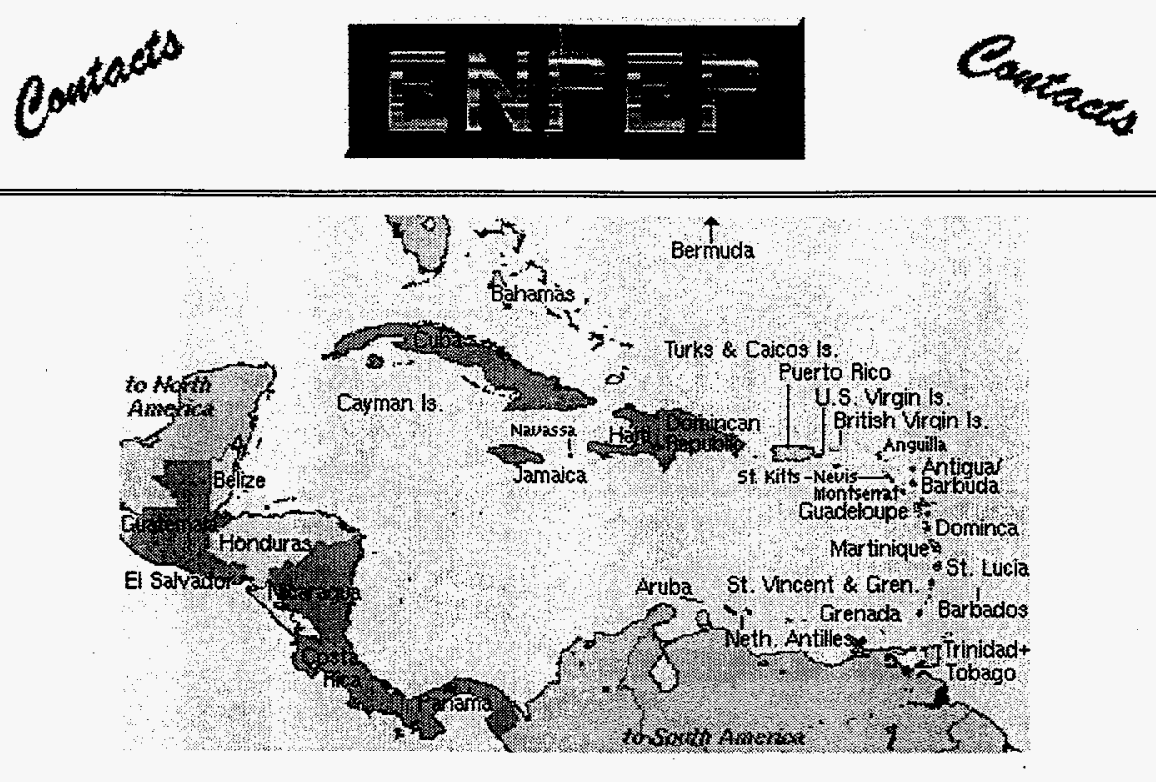

Click on a country. 

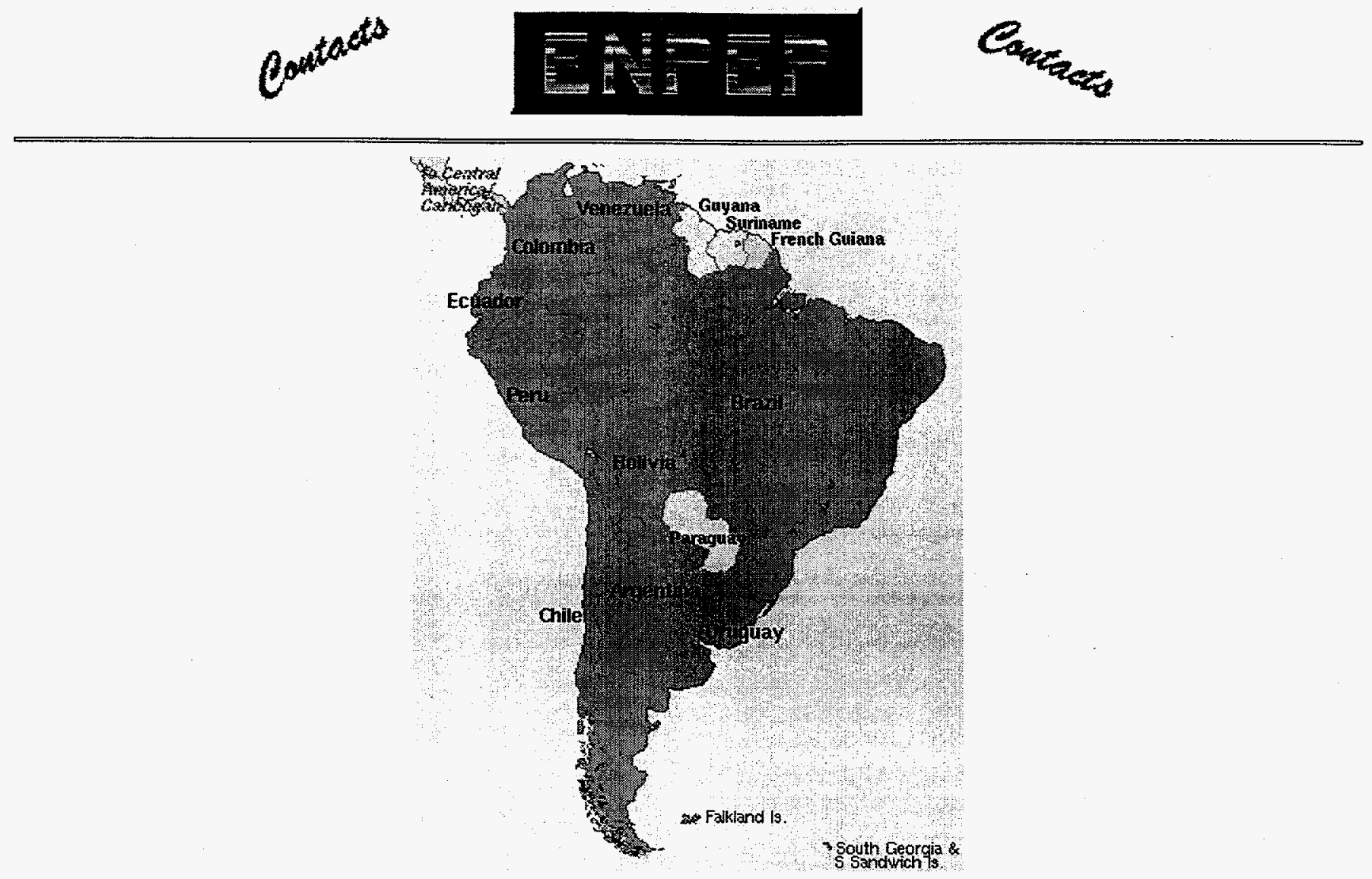

Click on a country. 


\title{
ALPHABETICAL LISTING FOR ENPEP CONTACTS
}

\author{
A \\ ALBANIA \\ $M A E D-1 \&$ WASP-III (portion of ENPEP) \\ Ms. Irena Jorgoni \\ Chief of Energy Economics Department \\ Council of Ministers \\ National Committee of Energy \\ Bulevardi "Desmoret e Kombit \\ Tirana \\ ALBANIA
}

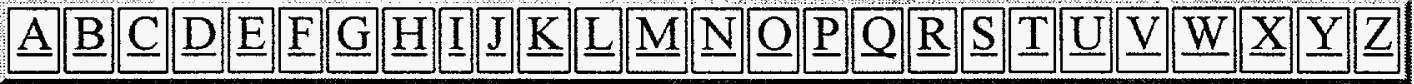

\author{
ALGERIA \\ ENPEP, MAED-I \& WASP-III (portion of ENPEP) \\ Mr. Abdoun Rachid \\ Societé Nationale de l'electricité et du Gaz, SANELGAZ \\ 2 Blvd. Colonel Krim Belkacem \\ Alger \\ ALGERIA
}

\section{ARGENTINA}




\title{
ENPEP \& WASP-III (portion of ENPEP)
}

\section{Mr. Francisco C. Rey}

Comisión Nacional de Energía Atómica (CNEA)

Avenida del Libertador 8250

1429 Buenos Aires

ARGENTINA

\section{AUSTRALIA}

$M A E D-1$

Mr. V. Srinivasan

South Australian Office of Energy Planning

Wakefield House

30 Wakefield Street

5000 Adelaide, S. Australia

AUSTRALIA
WASP-III (portion of ENPEP)

Mr. J. R. Fredsall

Austr. Nuclear Science \& Tecnology Lucas Height Research Laboratory Lucas Height, Private Mailbag 1

N.S.W. 2232

AUSTRALIA

\section{B}

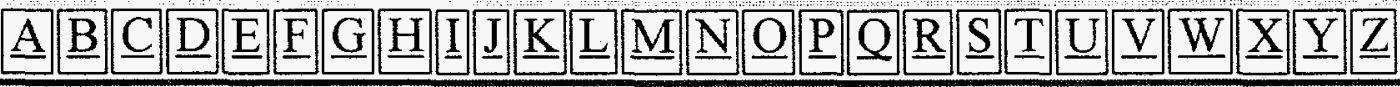

\section{BAHRAIN}

\author{
ENPEP \\ Mr. Aref Saleh Khamis \\ P.O. Box 333 \\ Manama \\ BAHRAIN
}

Ministry of Finance and National Economy

\section{BANGLADESH}


WASP-III (portion of ENPEP)

Mr. Haider Kabir

Bangladesh Power Dev. Board

WAPDA Building

Motijheel Com. Area

Dhaka

BANGLADESH

\section{BELARUS}

ENPEP, MAED-1 \& WASP-III (portion of ENPEP)

Mr. Anatoly Yakoushev

Institute of Power Engineering Problems

Academy of Sciences of Belarus, Sonsny

220109 Minsk

Republic of BELARUS

\section{BOLIVIA}

\section{WASP-III (portion of ENPEP)}

Ing. Enrique Gómez

Empresa Nacional de Electricidad S.A.

Calle Colombia 0-0655

Casilla de Correo 565

Cochabamba

BOLIVIA

\section{BRAZIL}




\section{ENPEP}

Mr. Luis C. Sizenando Silva

Energy Planning Department

CEMIG, Av. Barbacena 1200

C.P. 992, 30161-974 Belo Horizonte

Minas Gerais

BRAZIL
WASP-III (portion of ENPEP)

Mr. Jair M. de Souza

Nuclebras Engenharia S.A.

NUCLEN

Rua Visconde de Ouro Preto, 5

22.250 Rio de Janeiro

BRAZIL

\section{BULGARIA}

ENPEP \& WASP-III (portion of ENPEP)

Mr. Dimitar Stoytchev

National Electric Company

Energokibernetika

Triaditza 8, 1000 Sofia

BULGARIA
$M A E D-1$

Mr. Dimitar Stoytchev

CEE Powercybernetics

8 Triaditza Str.

1000 Sofia

BULGARIA

\section{C}

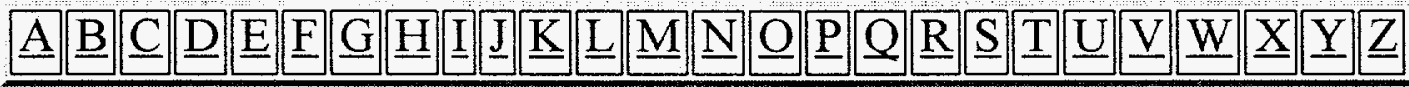

\section{CANADA}

ENPEP

Mr. Francis Dupuis

Hydro

Quebec

CANADA
WASP-III (portion of ENPEP)

Mr. William F. Seney

Market Analyst, National Energy Board

311 Sixth Avenue S.W.

Calgary, Alberta

CANADA T2P $3 \mathrm{H} 2$

\section{CHILE}


MAED-1 \& WASP-III (portion of ENPEP)

\section{Mr. Juan Magnasco Moretti}

Comisión Chilena de Energía Nuclear

Los Jesuitas 645

Casilla 188D

Santiago

CHILE
WASP-III (portion of ENPEP)

\section{Mr. Esteban Skoknic}

Empresa Nacional de Electricidad ENDESA

Santa Rosa 76

Santiago

CHILE

\section{CHINA}

ENPEP

Ms. Cheng Ping

China Institute of Nuclear Industry

Economics (CINIE)

P.O. Box 2103 (40)

Beijing 100037

CHINA
WASP-III (portion of ENPEP)

Dr. Li Zhen

Director, Beijing Water Resources and

Electrical Power Economic Research Institute

21 Wen Hua Lane

Xidan Bening, Beijing

CHINA

\section{COLOMBIA}

\section{ENPEP \& WASP-III (portion of ENPEP)}

Mr. Carlos Sánchez

Instituto de Asuntos Nucleares y Energías Alternativas (INEA)

Av. El Dorado Carrera 50

Apartado Aéreo 8595

Bogotá

COLOMBIA

\section{COSTA RICA}


WASP-III (portion of ENPEP)

Ing. Héctor Vargas $\mathbf{F}$.

Instituto Costarricense de Electricidad (ICE)

Apdo.10032 - San José

COSTA RICA

\section{CROATIA}

ENPEP

Mr. Boris Maksijan

Ministry of Economy

Avenija Vukovar 78

41000 Zagreb

CROATIA
MAED-1 \& WASP-III (portion of ENPEP)

Mr. Mladen Zeljko

Institut za Elektroprivredu i energetiku

Avenija Vukovar 37

41000 Zagreb

CROATIA

\section{CUBA}

MAED-1

Mr. Ector Delgado

Unión Eléctrica

Ministerio de la Industria Básica

Habana

CUBA

\section{CYPRUS}


WASP-III (portion of ENPEP)

Mr. George Kountouris

Chief Engineer \& General Manager

Electricity Authority of Cyprus

P.O. Box 4506

Nicosia

CYPRUS

Mr. Costas Charalambous

Planning Department

Electricity Authority of Cyprus

15 Photis Pittas Street

P.O. Box 4506

Nicosia

CYPRUS

\section{CZECH REPUBLIC}

MAED-1

Mr. Jiri Spitz

Research Institute of Fuel \& Energy Complex

Czechoslovak Atomic Energy Commission

Slezska 9, 12029 Prague 2

CZECH REPUBLIC
WASP-III (portion of ENPEP)

Mr. Jiri Martinek

Research Institute of Fuel \& Energy Complex

Czechoslovak Atomic Energy Commission

Slezska 9, 12029 Prague 2

CZECH REPUBLIC

\section{D}

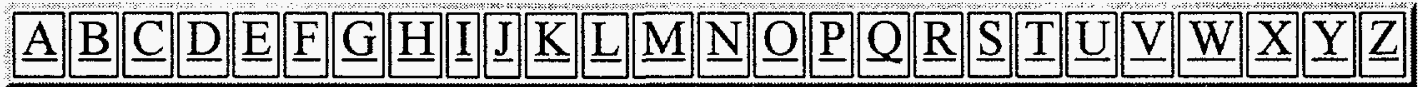

DOMINICAN REPUBLIC

WASP-III (portion of ENPEP)

Ing. Marcelo Jorge Pérez

Corporación Dominicana de Electricidad

Santo Domingo, D.N.

DOMINICAN REPUBLIC 
$\mathbf{E}$

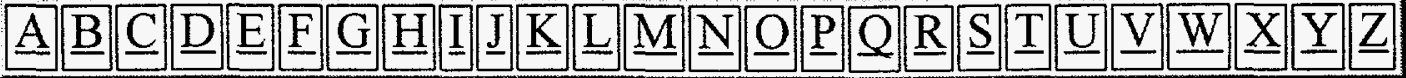 \\ ECUADOR}

MAED-1

Econ. Rubén Suárez

Dirección de Planificación

Instituto Ecuatoriano de Electrificación - INECEL

Av. 6 de Diciembre 2275 y Av. Orellana

Casilla 565-A

Quito

ECUADOR
WASP-III (portion of ENPEP)

Mr. A. Castro Collantes

Comisión Ecuatoriana de Energía Atómica

(CEEA)

Presidencia de la República

C. San Javier 295 y Av. Orellana

Quito

ECUADOR

WASP-III (portion of ENPEP)

Ing. Gonzalo Páez Ch.

Dirección de Planificación

Instituto Ecuatoriano de Electrificación - INECEL

Av. 6 de Diciembre 2275 y Av. Orellana

Casilla 565-A

Quito

ECUADOR

\section{EGYPT}

ENPEP

Mr. Hamed Aly Hamed Korkor Organization for Energy Planning (OEP) 1, Aisha Taymoryia Street

Garden City, Cairo

EGYPT
MAED-1

Dr. Emad El-Sharkawi

Chairman

Egyptian Electricity Authority - EEA

Nasr City - Abbassia

EGYPT 
WASP-III (portion of ENPEP)

Eng. Maher Abaza

Nuclear Power Plants Authority

Ministry of Electricity and Energy

4 Av. El-Nasr City, Cairo

EGYPT

\section{EL SALVADOR}

WASP-III (portion of ENPEP)

Mr. Oscar R. Melgar

Comisión Ejecutiva

Hidroeléctrica del Río Lempa

9a. Calle Poniente No. 950

San Salvador

EL SALVADOR

\section{ESTONIA}

WASP-III (portion of ENPEP)

Mr. Tanel Kaasik

EESTI Energia

1, Estonia Pst.

EE0100 Tallinn

ESTONIA

\section{ETHIOPIA}


WASP-III (portion of ENPEP)

Mr. Mekonnen Lulie

Ethiopian Energy Authority

P.O. Box 486

Addis Ababa

ETHIOPIA

\section{$\mathbf{F}$}

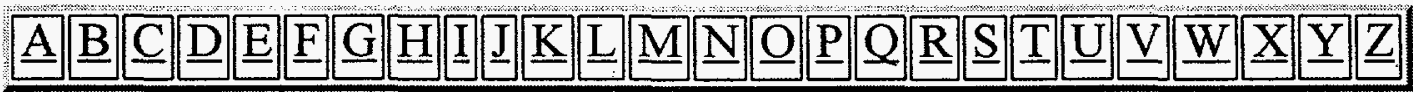

\section{FINLAND}

WASP-III (portion of ENPEP)

Mr. Euro Tamminen

Technical Research Centre of Finland

VTT-ENERGY

P.O. Box 1606

SF - 02044 VTT - ESPOO

FINLAND

\section{FRANCE}

MAED-1 \& WASP-III (portion of ENPEP)

\section{Mr. Bertrand Chateau}

Institut Economique et Juridique de l'Energie

Université des Sciences Sociales de Grenoble

B.P. 47X, Grenoble Cedex F-38040

FRANCE 


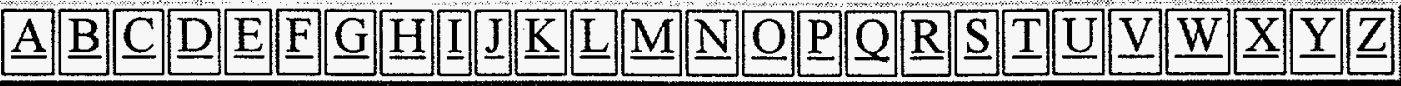

\section{GERMANY}

MAED-1 \& WASP-III (portion of ENPEP)

Mr. Reuter Albrecht

Institut für Energiewirtshaft

und Rationelle Energieanwendung

Universität Stuttgart, IKE

Pfaffenwaldring 31

Postfach 801140

7000 Stuttgart 80

GERMANY
WASP-III (portion of ENPEP)

Mr. K. Schippers

Institut für Elektrische Anlagen

und Energiewirtschaft - LL

RWTH Aachen, Schinkelstrasse 6

D-5100 Aachen

GERMANY

\section{GHANA}

MAED-1 \& WASP-III (portion of ENPEP)

Mr. Herbert Boadu

National Nuclear Research Institute

Ghana Atomic Energy Commission

P.O. Box 80, Legon-Accra

GHANA

\section{GREECE}

MAED-1 \& WASP-III (portion of ENPEP)

Mr. Spyros Vassos

Public Power Corporation

Department of Strategy and Planning

32 Arachovis Street

10681 Athens

GREECE 


\section{GUATEMALA}

$M A E D-1 \& W A S P-I I I$ (portion of ENPEP)

\section{Ing. Juan L. Guzmán R.}

Instituto Nacional de Electrificación (INDE)

7a. Avenida 2-29, Zona 9

Unidad de Planificación del Sistema Eléctrico (UPSE-INDE)

Edificio "La Torre".

Guatemala City

GUATEMALA

\section{$\mathbf{H}$}

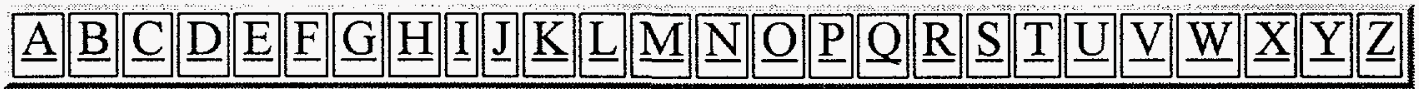

\section{HAITI}

WASP-III (portion of ENPEP)

Mr. Reynold Desrouleaux

Rue Dantes Destouches

Boîte postale 1753

Port-au-Prince

HAITI 
ENPEP \& WASP-III (portion of ENPEP)

Mr. Milhály Bacskó

Hungarian Power Companies Ltd. (MVM)

Dept. of Power Plants Operation

Vam u. 5-7

H-1011 Budapest

HUNGARY
MAED-1

Mr. Péter Dörfner

Hungarian Electricity Board

(MVMT), Vam u. 5-7

H-1011 Budapest

HUNGARY

\section{I}

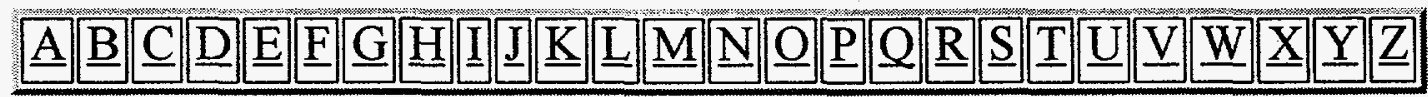

ICELAND

WASP-III (portion of ENPEP)

Mr. E. G. Hreinsson

University of Iceland

Faculty of Engineering

Hjardarhagi 2-6

107 Reykjavik

ICELAND

\section{INDIA}

WASP-III (portion of ENPEP)

Mr. S. K. Aggarwal

Central Electricity Authority

Sewa Bhavan, R. K. Puran

New Delhi-110066

INDIA 


\section{INDONESIA}

ENPEP \& WASP-III (portion of ENPEP)

Mr. Adiwardojo
Badan Tenaga Atom Nasional
JL. K. H. Abdul Rohim
Jakarta 12710
INDONESIA

$M A E D-1$

Mr. M. Djokolelono

Badan Tenaga Atom Nasional

BATAN

Jl. K.H. Abdul Rochim

Mampang Prapatan

Jakarta Selatan

INDONESIA

\section{IRAN}

\section{ENPEP \& WAPS-III (portion of ENPEP)}

Mr. Msoud Shakiba
Iran Electric Organization
Director of Generation Planning Dept.
Vali-Asr Ave., Shahrdary St
P.O. Box 19835-359
Tehran
IRAN

\section{ISRAEL}

ENPEP

Mr. D. Soloveitchik

Ministry of Energy \& Infrastructure

234 Jaffa Street

91130 Jerusalem

ISRAEL
WASP-III (portion of ENPEP)

Mr. A. Barak

Israel Atomic Energy Commission

P.O. Box 7061. Tel-Aviv

ISRAEL

\section{ITALY}




\section{WASP-III (portion of ENPEP)}

Mr. A. Rivoiro

Ente Nazionale per l'Energia Elettrica

ENEL/DSR-CREI

Via A. Volta, 1

20093 Cologno Monzense

ITALY

\section{$\mathbf{J}$}

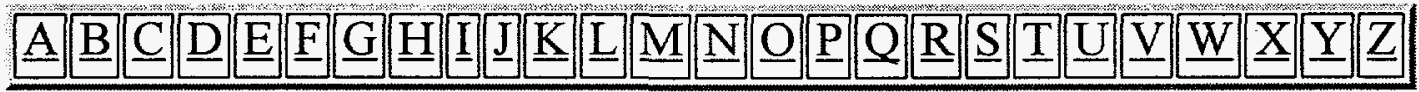

JAMAICA

WASP-III (portion of ENPEP)

Mr. Hopeton Heron

Manager, System Planning

Jamaica Public Service Co.

6 Knutsford Blvd.

Kingston 10

JAMAICA

\section{JAPAN}

WASP-III (portion of ENPEP)

Mr. Atsushi Fukushima

Institute of Energy Economics

Shuwa Kamiyachou Building

3-13 Toranomon 4-chome

Minato-u, Tokyo

JAPAN 


\title{
JORDAN
}

\author{
ENPEP \\ Mr. Mahmoud Al-Ees \\ Ministry of Energy and Mines \\ P.O. Box 140027 Wadi Sier \\ Amman \\ JORDAN
}

$M A E D-1 \& W A S P-I I I$ (portion of ENPEP)

Mr. M. Azzam

Jordan Electricity Authority

P.O. Box 2310

Amman

JORDAN

\section{$\mathbf{K}$}

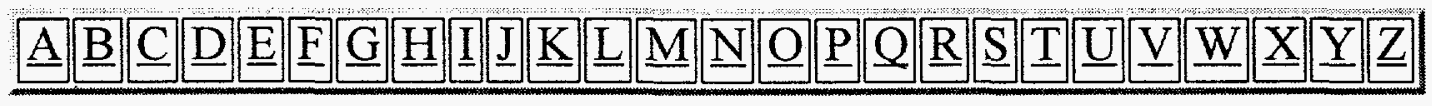

\section{KAZAKHSTAN}

\section{ENPEP, MAED-1 \& WASP-III (portion of ENPEP)}

\section{Mr. Tleusen Temertekov}

Kazakh Scientific Research Hydrometeoroligical Institute (KazNIGMI)

Seilfullin pr. 597

Almaty 480072

KAZAKHSTAN

\section{KENYA}

\section{WASP-III (portion of ENPEP)}

Mr. D. M. Mwangi

Kenya Power \& Lighting Co.

Electric House, Harambee Ave.

P.O. Box 30099

Nairobi

KENYA 


\section{KUWAIT}

\section{ENPEP}

\section{Mr. Khelil Ben Afia}

Ministry of Oil

P.O. Box 5077

Safat

KUWAIT

\section{$\mathbf{L}$}

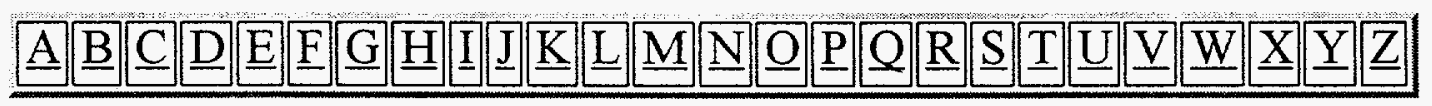

LIBYA

MAED-1 \& WASP-III (portion of ENPEP)

Mr. Haddud H. Haddud

General Electric Co.

P.O. Box 668

Tripoli

LIBYA

\section{LITHUANIA}

MAED-1 \& WASP-III (portion of ENPEP)

\section{Mr. Vaclovas Miskinis}

Head of Department

Lithuanian Energy Institute

Breslaujos 3

3035 Kaunas

LITHUANIA 


\section{M}

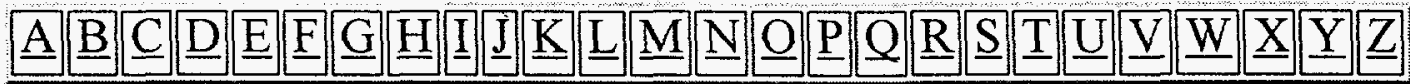

MACEDONIA

\section{WASP-III (portion of ENPEP)}

Prof. Dr. Tome Bosevski

Elektrotehnicki fakultet

Karpos II, bb, P.O. Box 574

91000 Skopje

MACEDONIA

\section{MADAGASCAR}

\section{MAED-1}

Mr. Gervais Rasamoelina

Jiro Sy Rano Malagasy

JIRAMA

149 , rue Rainandriamampandry

101 Antananarivo

MADAGASCAR
WASP-III (portion of ENPEP)

Mr. Majilo Ratsimiebo

Jiro Sy Rano Malagasy

149, rue Rainandriamampandry

B.P. 200, Antananarivo 101

MADAGASCAR

\section{MALAYSIA}

ENPEP

Mohd. Zamzam bim Jaafar

Tenaga Nasional Berhad

129 Jalan Bangsar

P.O. Box 1003, Kuala Lumpur

MALAYSIA
MAED-1

Mr. Pian Bin Sukro

Tenaga Nasional Berhad

129 Jalan Bangsar

P.O. Box 1003, Kuala Lumpur

MALAYSIA 
WASP-III (portion of ENPEP)

Mr. Jalaludding bim Zainuddin

Tenaga Nasional Berhad

129 Jalan Bangsar

P.O. Box 1003, Kuala Lumpur

MALAYSIA

\section{MAURITIUS}

MAED-1 \& WASP-III (portion of ENPEP)

\section{Mr. P.M.K. Soonarane}

Ministry of Energy. Water Resources \& Postal Services

Government Centre

Port Louis

MAURITIUS

\section{MEXICO}

ENPEP \& WASP-III (portion of ENPEP)

Mr. Isaac Jiménez Lerma

Comisión Federal de Electricidad

Planning Department

León Tolstoi No. 29, Piso 13

$11590 \mathrm{MEXICO}$, D.F.

\section{MOLDOVA}


WASP-III (portion of ENPEP)

Mr. Silvia Cociu

Department of Energy and Energy Resources

50 Mihai Eminescu Street

227012 Chishinev

MOLDOVA

\section{Mr. Stefan Puiu}

Department of Energy and Energy Resources

50 Mihai Eminescu Street

227012 Chishinev

MOLDOVA

\section{MONGOLIA}

\section{WASP-III (portion of ENPEP)}

Mr. P. Baatar

Central Energy System

Ministry of Fuel \& Energy

Ulaanbaatar

MONGOLIA

\section{MOROCCO}

\author{
ENPEP \\ Mr. Mohamed Fadili \\ Office Nationale de l'Electricité \\ 65, Rue Aspirant Lafuente \\ Casablanca \\ MOROCCO
}

\section{WASP-III (portion of ENPEP)}

Mr. Kettani Zine Laabidine

Office Nationale de l'Electricité (ONE)

65, Rue Aspirant Lafuente, B.P. 498

Casablanca

MOROCCO

\section{MYANMAR}




\section{MAED-1 \& WASP-III (portion of ENPEP)}

\section{Mr. W. Soe Myint Lwin}

Myanma Electric Power Enterprise (MEPE)

No. 23, Pyay Road

Rangoon

MYANMAR

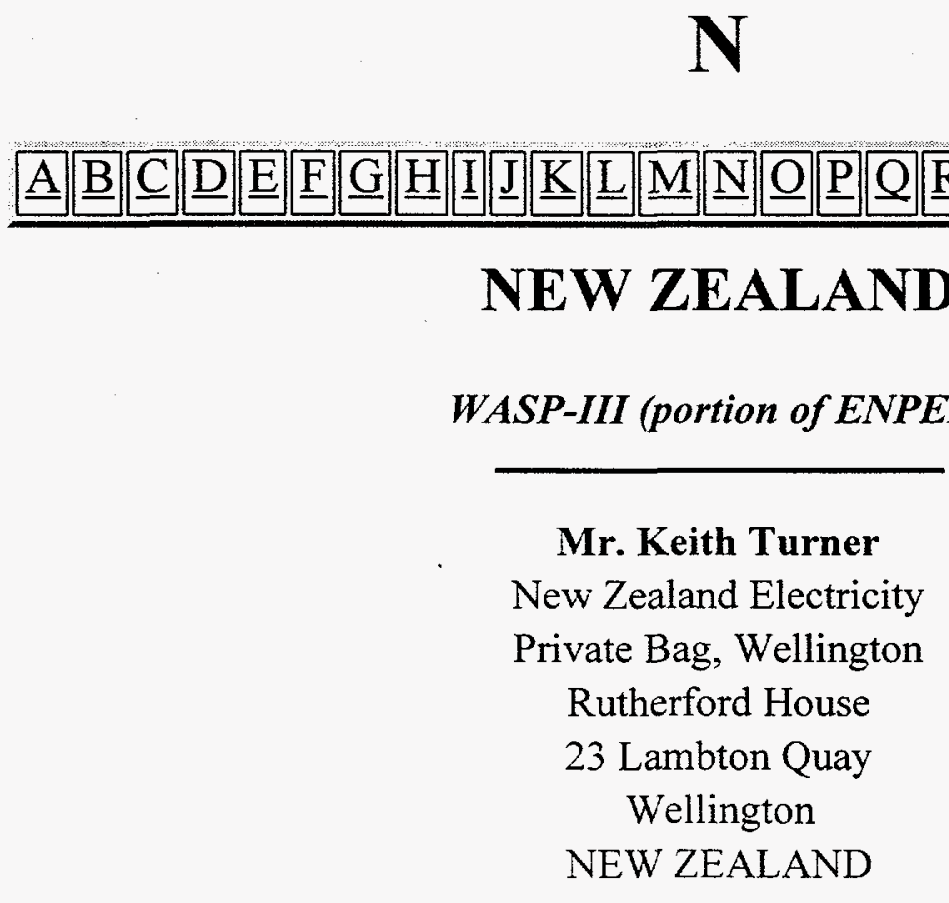

NICARAGUA

WASP-III (portion of ENPEP)

Mr. Emilio Rappaccioli

Empresa Nacional de Luz y Fuerza

Instituto Nicaragüense de Energía

Apartado 55, Managua, D.C.

NICARAGUA 


\section{NIGERIA}

\section{WASP-III (portion of ENPEP)}

Mr. D. A. Oyeyele

National Electricity Power Authority

Electricity Headquarters

24/25 Marina, P.M.B. 12030

Lagos

NIGERIA

\section{NORWAY}

MAED-1 \& WASP-III (portion of ENPEP)

Mr. Bjorn Grinden

Norwegian Electric Power Research Institute

N-7034 Trondheim

NORWAY

\section{$\mathbf{O}$}

Contact information could not be found on countries which begin with the letter ' $O$ '.

$\mathbf{P}$

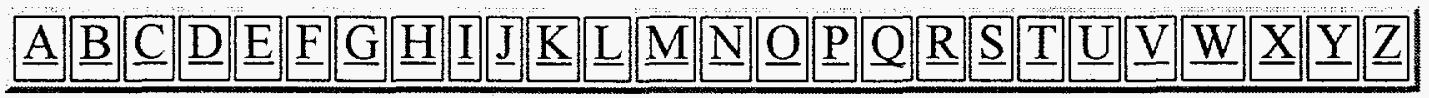

PAKISTAN 
ENPEP, MAED-1 \& WASP-III (portion of ENPEP)

Mr. Arshad M. Khan

Director, Applied System Analysis Group

Pakistan Atomic Energy Commission

P.O. Box 1114

Islamabad

PAKISTAN

\section{PANAMA}

WASP-III (portion of ENPEP)

Mr. O. Rondell

Instituto de Recursos Hidráulicos y Electrificación

Apartado 5285, Panamá 5

PANAMA

\section{PERU}

ENPEP \& WASP-III (portion of ENPEP)

Mr. César Pizarro

Instituto Peruano de Energía Nuclear

Avenida Canadá 1470

Lima 13

PERU

\section{PHILIPPINES}




\section{ENPEP \& WASP-III (portion of ENPEP)}

Mr. Rizalino Santos

Systems Planning Department

National Power Corporation

Cor. Agham Road \& Quezon Avenue

Diliman, Quezon City

PHILIPPINES

\section{POLAND}

ENPEP

Mr. Andrzej Kerner

Energy Information Center

Division of Energometrics

Mysia Street 2

P.O. Box 143

00-950 Warsaw

POLAND
MAED-1 \& WASP-III (portion of ENPEP)

Mr. D. Lucjan Twardy

Electric Power and Lignite Board

Mysia 2

00-496 Warsaw

POLAND

\section{PORTUGAL}

ENPEP

Mr. Joao Baptista

National Energy Plan

Ministry of Industry and Energy

Rua da Beneficencia, 241, $4^{\circ}$

1600 Lisboa

PORTUGAL
WASP-III (portion of ENPEP)

Mr. Jorge R. Machado

Electricidade de Portugal

Gabinete de Planeamento

Rua Sa da Bandeira 567

Apartado 99, 4009 Porto Cedex

PORTUGAL 


\section{with the letter ' $Q$ '.}

$\mathbf{R}$

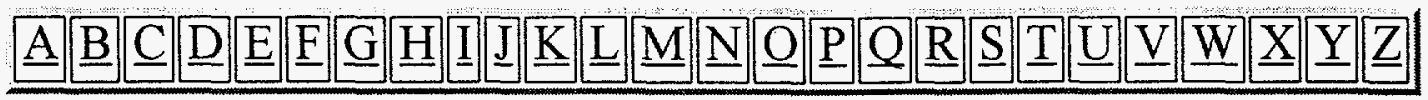

ROMANIA

ENPEP, MAED-I \& WASP-III (portion of ENPEP)

Ms. Anca Popescu

Institute of Power Studies and Design (ISPE)

$1 \mathrm{BD}$. Lacul Tei

P.O. Box 30

R72301 Bucharest

ROMANIA

\section{RUSSIA}

\section{ENPEP}

\section{Mr. Alexander Shibanov}

Main Computing Centre

Ministry of Fuel and Energy of the

Russian Federation

Kitaisvky pr. 7

134074 Moscow

RUSSIA FEDERATION
WASP-III (portion of ENPEP)

Mr. V. S. Kagramanian

Institute of Physics and Power Power Enginnering (IPPE)

Bondarenko Square I 249020 Obninsk Kaluga Region RUSSIA FEDERATION

\section{$\mathbf{S}$}

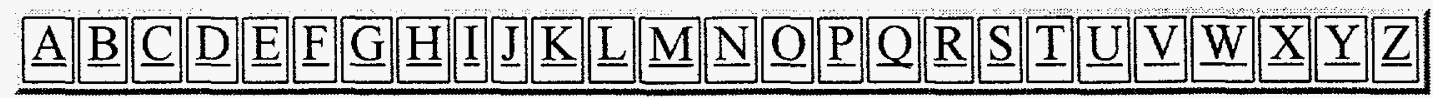




\section{ENPEP}

Ms. Ayse Soysal

State Planning Organization

Sectoral Programming Department

Necatibey St. 108

Ankara

SAUDI ARABIA

\section{MAED-1}

Dr. I. Al-Kharashi

King Abdulaziz City

for Science and Technology

P.O. Box 6086

Riyad 11442

- SAUDI ARABIA

WASP-III (portion of ENPEP)

Mr. Mohd. Ali-Al-Tasan

Information Systems and Technical Services

Saudi Arabian National Centre for Science and Technology

P.O. Box 6086

Riyadh

SAUDI ARABIA

\section{SINGAPORE}

\section{WASP-III (portion of ENPEP)}

Mr. Won Kow Ng

Public Utilities Board

Electricity Department

PUB Bldg. 111 Somerset Road

Singapore 0923

SINGAPORE

\section{SLOVAKIA}


ENPEP, MAED-1 \& WASP-III (portion of ENPEP)

Mr. Ivan Mojík

Director of Air Protection Department

Ministry of the Environment

Hlboká 2

81235 Bratislava

SLOVAKIA

\title{
SLOVENIA
}

MAED-1 \& WASP-III (portion of ENPEP)

Mr. Zvonko Bregar

Milan Bidmae Electroinstitute

Hajdrihova 2

61000 LjUbljana

SLOVENIA

\section{SOUTH KOREA}

\author{
WASP-III (portion of ENPEP) \\ Mr. Shin Mahn-Cherl \\ Korea Electric Power Corp. \\ 87, Samseong-Dong \\ Kang Nam Ku \\ Seoul \\ SOUTH KOREA
}

\section{SPAIN}


ENPEP

Mr. Francisco Mingot Buades

Centro de Investigaciones Energéticas,

Medioambientales y Tecnológicas (CIEMAT)

Avenida Complutense 22

28040 Madrid

SPAIN
ENPEP \& WASP-III (portion of ENPEP)

Mr. A. González de Ubieta

Unidad Eléctrica S.A. (UNESA)

C. Francisco Gervás No. 3

Madrid 20

SPAIN

\section{SRI LANKA}

ENPEP

Ms. Kamani Jayasekera

Ceylon Electricity Board

P.O. Box 540

Colombo

SRI LANKA
WASP-III (portion of ENPEP)

Mr. T. Siyambalapitiya

Generation Planning Branch

Ceylon Electricity Board

P.O. Box 540

Colombo

SRI LANKA

\section{SUDAN}

ENPEP

Mr. Haroun Osman Sam

National Electricity Corporation (NEC)

P.O. Box 1380

Khartoum

SUDAN

\section{SWEDEN}




\section{WASP-III (portion of ENPEP)}

\section{Dr. Jan Sundell}

The Swedish State Power Board

S-16287 Vällingby

SWEDEN

\section{SWITZERLAND}

\section{WASP-III (portion of ENPEP)}

\section{Mr. E. Gnansounou}

Institut d'hydraulique et d'énergie

LASEN-Laboratoire de systémes énérgetiques

Ecole polytechnique fédérale de Lausanne - GCB (Ecublens)

$\mathrm{CH}-1015$ Lausanne

SWITZWERLAND

\section{SYRIA}

WASP-III (portion of ENPEP)

Mr. Khaled Homsi

Studies and Scientific Researches Centre

P.O. Box 4470

Damascus

SYRIA ARAB REPUBLIC

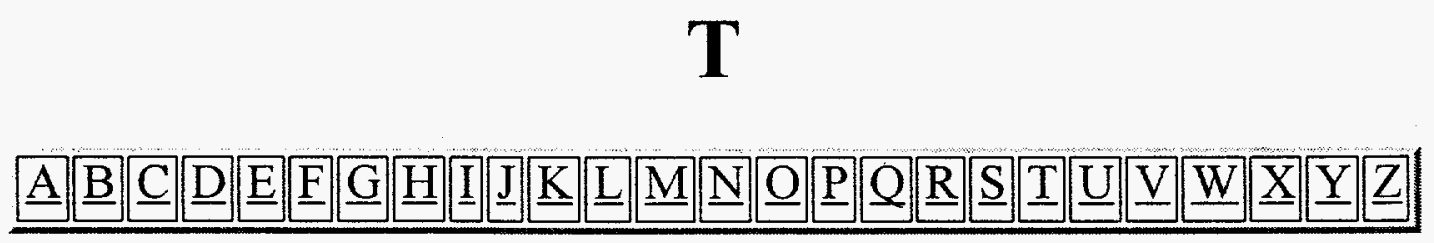

TANZANIA 
Ms. Justina P.L. Uisso

Ministry of Water, Energy and Minerals

P.O. Box 2000

Dar Es Salaam

TANZANIA
Prof. H. Y. Kayumbo

National Scientific Research Council

P.O. Box 4302

Dar es Salaam

TANZANIA

\section{THAILAND}

MAED-1

Mr. K. Vongsuriya

Electricity Generating Authority of Thailand - EGAT

Nonthaburi

Bangkok

THAILAND
WASP-III (portion of ENPEP)

Somkiet Phaloprakarn

Electricity Generating Authority of Thailand EGAT

Nonthaburi

Bangkok

THAILAND

\section{TUNISIA}

ENPEP \& WASP-III (portion of ENPEP)

\section{Mr. Hedi Turki}

Societé Tunisienne de l'Electricité et du Gaz (STEG)

$$
\begin{gathered}
38 \text { rue Kémal Ataturk } \\
1021 \text { Tunis } \\
\text { TUNISIA }
\end{gathered}
$$

MAED-1

Mr. Ahmed Ounali

Agence de Maitrise de

L'Energie - AME

8 rue Ibn El Jazzan

1002 Tunis

TUNISIA

MAED-1

\section{Mr. Moncef El Aroui}

Direction des Etudes et de la Planification (STEG)

38 rue Kémal Ataturk

1021 Tunis

TUNISIA 


\section{TURKEY}

\section{$M A E D-1$}

\section{Mr. Sefik Ozanozcu}

Enerji ve Tabil Kaynaklar

Basbakanligi, Konya Yalu

Ankara

TURKEY

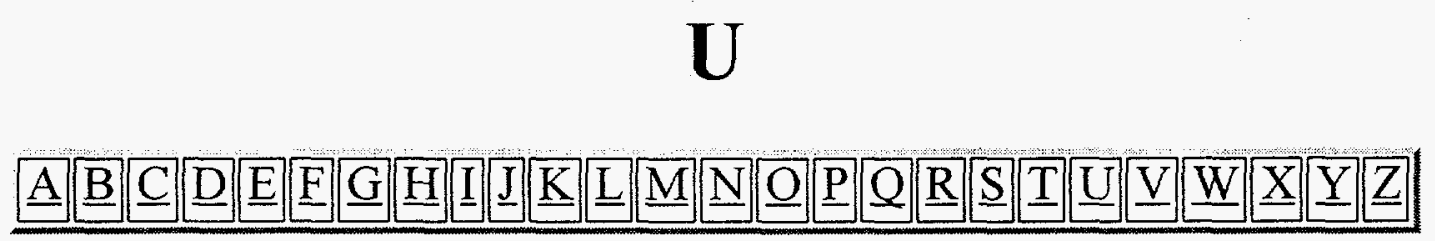

UKRAINE

ENPEP \& WASP-III (portion of ENPEP)

Ms. Elena Ivanovna Dyakova

Reactor Physics Section of the Nuclear

Power Dept. of Nuclear Research Institute of the Ukrainian National Academy of Sciences

252650, Kiev-20

UKRAINE

\section{UNITED KINGDOM}




\title{
WASP-III (portion of ENPEP)
}

\section{Dr. H. W. Whittington}

Department of Electrical Eng.

The University of Edinburgh

The King's Building

Mayfield Road

Edinburgh EH9 3JL

Scotland

U.K.

\section{U.S.A.}

\section{ENPEP}

\section{Mr. William Buehring}

Argonne National Laboratory

DIS Building 900

9700 South Cass Avenue

Argonne, IL 60439

U.S.A.

\section{URUGUAY}

\author{
ENPEP \\ Ing. Roald Reolon \\ Dirección Nacional de Energía \\ Ministerio de Industria, Energía y Minería \\ Rincón 723, Piso 3 \\ C.P. 11000 \\ Montevideo \\ URUGUAY
}




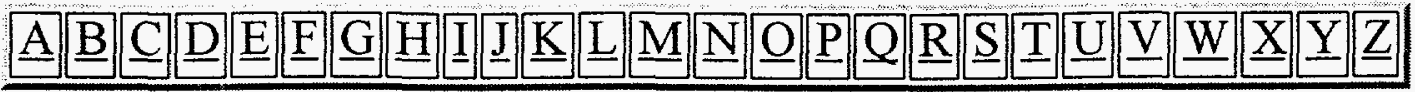 VENEZUELA}

\author{
ENPEP \& WASP-III (portion of ENPEP) \\ Mr. Luis A. Villanueva \\ Dirección de Planificación Energética \\ Ministerio de Energía y Minas \\ Torre Oeste, Piso 17 \\ Parque Central, Caracas \\ VENEZUELA
}

MAED-1

Mr. Carlos Avilés Mares

Ministerio de Energía y Minas, Dirección Gral.

Sectorial de Energía

Torre Oeste, Piso 17

Parque Central, Caracas

VENEZUELA

\section{VIETNAM}

\section{WASP-III (portion of ENPEP)}

Mr. Dihn Ngoc Lan

National Institute for Nuclear Research of Vietnam

67 Nguyen Du Mansi

VIETNAM

\section{W}

\section{Contact information could not be found on countries which begin with the letter ' $W$ '.}

\section{$\mathbf{X}$}

\section{Contact information could not be found on countries which begin with the letter ' $X$ '.}




\title{
Y

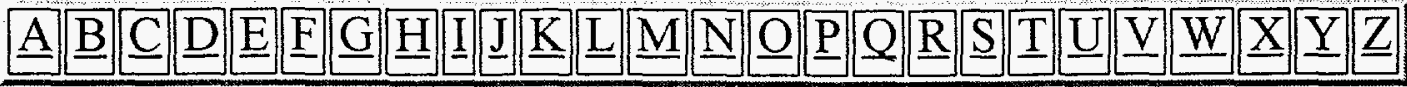 YUGOSLAVIA
}

ENPEP, MAED-1, WASP-III (portion of ENPEP)

Mr. Zoran Sretenovic

Union of Yugoslav Electric Power Industry, JUGEL

Development and International Relations Division Balkanska 13 11000 Belgrade YUGOSLAVIA
WASP-III (portion of ENPEP)

Mr. A. Kocic

Boris Kidric Institute

Nuclear Engineering Lab.

P.O. Box 522, YU-11001

Belgrade

YUGOSLAVIA

\section{$\mathbf{Z}$}

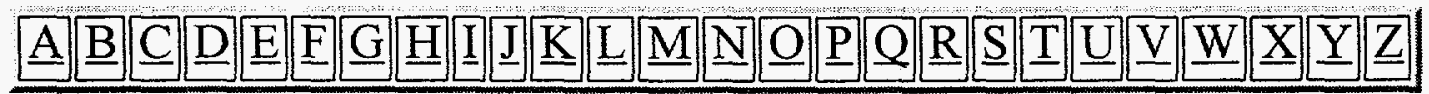

\section{ZAMBIA}

WASP-III (portion of ENPEP)

\author{
Dr. Japhet D. Sakala \\ Director, Corporate Affairs \\ ZESCO \\ P.O. Box 33304 \\ Lusaka \\ ZAMBIA
}

Zambia Electric and Supply Corporation

\section{ZIMBABWE}


$M A E D-1 \& W A S P-I I I$ (portion of ENPEP)

Mr. D. Madzikanda

Zimbabwe Electricity Supply Authority

System Planning

P.O. Box 377

Harare

ZIMBABWE

For address corrections or additions to any countries in our ENPEP directory please send an e-mail to enpep@anl.gov 


\section{CANADA}

ENPEP

WASP-III (portion of ENPEP)

Mr. Francis Dupuis

Hydro

Quebec

CANADA

Mr. William F. Seney

Market Analyst, National Energy Board

311 Sixth Avenue S.W.

Calgary, Alberta

CANADA T2P 3H2

\section{MEXICO}

ENPEP \& WASP-III (portion of ENPEP)

Mr. Isaac Jiménez Lerma

Comisión Federal de Electricidad

Planning Department

León Tolstoi No. 29, Piso 13

11590 MÉXICO, D.F.

\section{U.S.A.}

MAED-1 \& WASP-III (portion of ENPEP)

Mr. William Buehring

Argonne National Laboratory

DIS-Building 900

9700 South Cass Avenue

Argonne, IL 60439

$$
\text { U.S.A. }
$$

For address corrections send an e-mail towebmaster@enpep.dis.anl.gov 

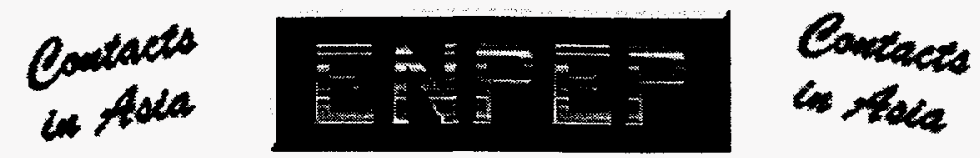

\section{BANGLADESH}

WASP-III (portion of ENPEP)

Mr. Haider Kabir

Bangladesh Power Dev. Board

WAPDA Building

Motijheel Com. Area

Dhaka

BANGLADESH

\section{CHINA}

\section{ENPEP}

Ms. Cheng Ping

China Institute of Nuclear Industry

Economics (CINIE)

P.O. Box 2103 (40)

Beijing 100037

CHINA
WASP-III (portion of ENPEP)

Dr. Li Zhen

Director, Beijing Water Resources and

Electrical Power Economic Research Institute

21 Wen Hua Lane

Xidan Bening, Beijing

CHINA

\section{INDIA}

\section{WASP-III (portion of ENPEP)}

Mr. S. K. Aggarwal

Central Electricity Authority

Sewa Bhavan, R. K. Puran

New Delhi-110066

INDIA

\section{INDONESIA}




\section{INDONESIA}

ENPEP \& WASP-III (portion of ENPEP)

Mr. Adiwardojo

Badan Tenaga Atom Nasional

JL. K. H. Abdul Rohim

Jakarta 12710

INDONESIA
MAED-I

Mr. M. Djokolelono

Badan Tenaga Ȧtom Nasional

BATAN

Jl. K.H. Abdul Rochim

Mampang Prapatan

Jakarta Selatan

INDONESIA

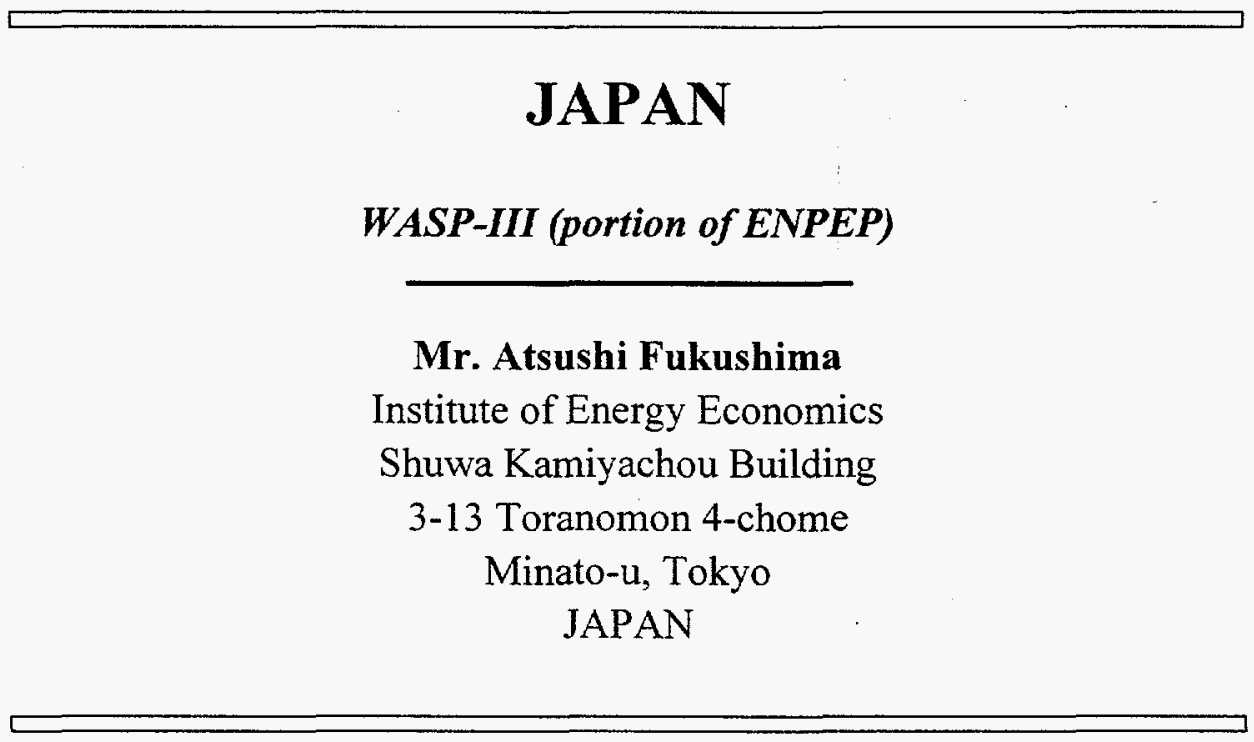

\section{KAZAKHSTAN}

ENPEP, MAED-1 \& WASP-III (portion of ENPEP)

Mr. Tleusen Temertekov

Kazakh Scientific Research Hydrometeoroligical Institute (KazNIGMI)

Seilfullin pr. 597

Almaty 480072

KAZAKHSTAN

\section{MALAYSIA}

ENPEP

Mohd. Zamzam bim Jaafar
MAED-1

Mr. Pian Bin Sukro 
Mohd. Zamzam bim Jaafar

Tenaga Nasional Berhad

129 Jalan Bangsar

P.O. Box 1003, Kuala Lumpur

MALAYSIA
Mr. Pian Bin Sukro

Tenaga Nasional Berhad

129 Jalan Bangsar

P.O. Box 1003, Kuala Lumpur

MALAYSIA

WASP-III (portion of ENPEP)

Mr. Jalaludding bim Zainuddin

Tenaga Nasional Berhad

129 Jalan Bangsar

P.O. Box 1003, Kuala Lumpur

MALAYSIA

\section{MONGOLIA}

WASP-III (portion of ENPEP)

Mr. P. Baatar

Central Energy System

Ministry of Fuel \& Energy

Ulaanbaatar

MONGOLIA

\section{MYANMAR}

MAED-1 \& WASP-III (portion of ENPEP)

Mr. W. Soe Myint Lwin

Myanma Electric Power Enterprise (MEPE)

No. 23, Pyay Road

Rangoon

MYANMAR

\section{NEPAL}

\section{ENPEP}


NEPAL

\section{PAKISTAN}

\section{ENPEP, MAED-1 \& WASP-III (portion of ENPEP)}

Mr. Arshad M. Khan

Director, Applied System Analysis Group

Pakistan Atomic Energy Commission

P.O. Box 1114

Islamabad

PAKISTAN

\section{PHILIPPINES}

ENPEP \& WASP-III (portion of ENPEP)

Mr. Rizalino Santos

Systems Planning Department

National Power Corporation

Cor. Agham Road \& Quezon Avenue

Diliman, Quezon City

PHILIPPINES

\section{RUSSIA}

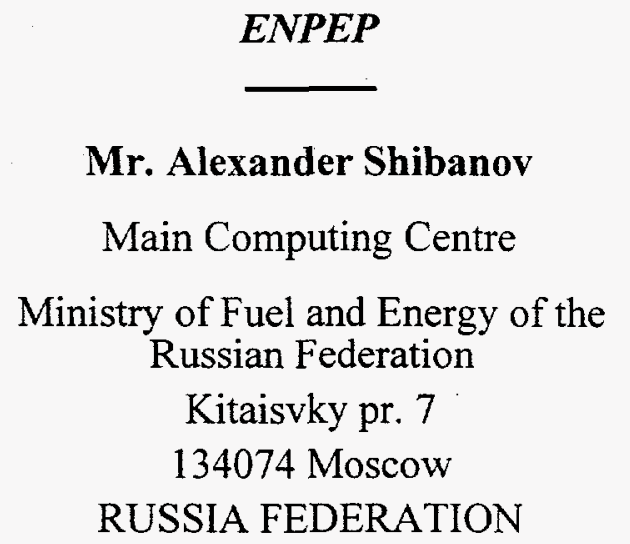

ENPEP

Mr. Alexander Shibanov

Main Computing Centre

Russian Federation

Kitaisvky pr. 7

RUSSIA FEDERATION
WASP-III (portion of ENPEP)

Mr. V. S. Kagramanian

Institute of Physics and Power Power Enginnering (IPPE)

Bondarenko Square I 249020 Obninsk

Kaluga Region

RUSSIA FEDERATION 


\title{
SINGAPORE
}

\section{WASP-III (portion of ENPEP)}

Mr. Won Kow Ng

Public Utilities Board

Electricity Department

PUB Bldg. 111 Somerset Road

Singapore 0923

SINGAPORE

\section{SOUTH KOREA}

\section{WASP-III (portion of ENPEP)}

\author{
Mr. Shin Mahn-Cherl \\ Korea Electric Power Corp. \\ 87, Samseong-Dong \\ Kang Nam Ku \\ Seoul \\ SOUTH KOREA
}

\section{SRI LANKA}

ENPEP

Ms. Kamani Jayasekera

Ceylon Electricity Board

P.O. Box 540

Colombo

SRI LANKA
WASP-III (portion of ENPEP)

Mr. T. Siyambalapitiya

Generation Planning Branch

Ceylon Electricity Board

P.O. Box 540

Colombo

SRI LANKA

\section{THAILAND}


WASP-III (portion of ENPEP)

Mr. K. Vongsuriya Somkiet Phaloprakarn

Electricity Generating Authority of Thailand - EGAT

Nonthaburi EGAT

Bangkok

Nonthaburi

THAILAND

THAILAND

\title{
VIETNAM
}

WASP-III (portion of ENPEP)

\author{
Mr. Dihn Ngoc Lan
}

National Institute for Nuclear Research of Vietnam

67 Nguyen Du Mansi

VIETNAM

For address corrections send an e-mail towebmaster@enpep.dis.anl.gov 

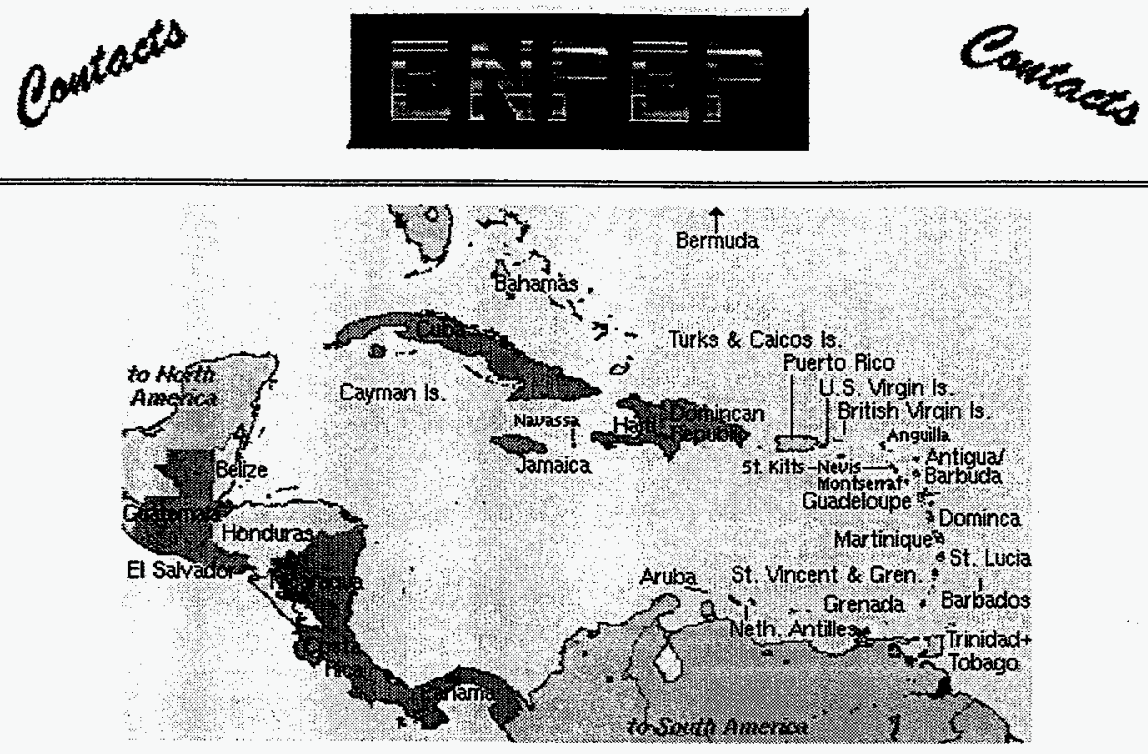

Click on a country. 
ARGENTINA

ENPEP \& WASP-III (portion of ENPEP)

Mr. Francisco C. Rey

Comisión Nacional de Energía Atómica (CNEA)

Avenida del Libertador 8250

1429 Buenos Aires

ARGENTINA

\section{BOLIVIA}

WASP-III (portion of ENPEP)

Ing. Enrique Gómez

Empresa Nacional de Electricidad S.A.

Calle Colombia 0-0655

Casilla de Correo 565

Cochabamba

BOLIVIA

\section{BRAZIL}

ENPEP

Mr. Luis C. Sizenando Silva

Energy Planning Department

CEMIG, Av. Barbacena 1200

C.P. 992, 30161-974 Belo Horizonte

Minas Gerais

BRAZIL
WASP-III (portion of ENPEP)

Mr. Jair M. de Souza

Nuclebras Engenharia S.A.

NUCLEN

Rua Visconde de Ouro Preto, 5

22.250 Rio de Janeiro

BRAZIL

\section{CHILE}


MAED-1 \& WASP-III (portion of ENPEP)

Mr. Juan Magnasco Moretti

Comisión Chilena de Energía Nuclear

Los Jesuitas 645

Casilla 188D

Santiago

CHILE
WASP-III (portion of ENPEP)

Mr. Esteban Skoknic

Empresa Nacional de Electricidad -

ENDESA

Santa Rosa 76

Santiago

CHILE

\title{
COLOMBIA
}

\section{ENPEP \& WASP-III (portion of ENPEP)}

\author{
Mr. Carlos Sánchez \\ Instituto de Asuntos Nucleares y Energías Alternativas (INEA) \\ Av. El Dorado Carrera 50 \\ Apartado Aéreo 8595 \\ Bogotá \\ COLOMBIA
}

\section{ECUADOR}

MAED-1

Econ. Rubén Suárez

Dirección de Planificación

Instituto Ecuatoriano de

Electrificación - INECEL

Av. 6 de Diciembre 2275 y Av.

Orellana

Casilla 565-A

Quito

ECUADOR
WASP-III (portion of ENPEP)

Mr. A. Castro Collantes

Comisión Ecuatoriana de Energía Atómica (CEEA)

Presidencia de la República

C. San Javier 295 y Av. Orellana

Quito

ECUADOR 


\title{
WASP-III (portion of ENPEP)
}

Ing. Gonzalo Páez Ch.

Dirección de Planificación

Instituto Ecuatoriano de Electrificación - INECEL

Av. 6 de Diciembre 2275 y Av. Orellana

Casilla 565-A

Quito

ECUADOR

\section{PERU}

ENPEP \& WASP-III (portion of ENPEP)

Mr. César Pizarro

Instituto Peruano de Energía Nuclear

Avenida Canadá 1470

Lima 13

PERU

\section{URUGUAY}

\author{
ENPEP \\ Ing. Roald Reolon \\ Dirección Nacional de Energía \\ Ministerio de Industria, Energía y Minería \\ Rincón 723, Piso 3 \\ C.P. 11000 \\ Montevideo \\ URUGUAY
}


ENPEP \& WASP-III (portion of ENPEP)

Mr. Luis A. Villanueva

Dirección de Planificación Energética

Ministerio de Energía y Minas

Torre Oeste, Piso 17

Parque Central, Caracas

VENEZUELA
MAED-1

Mr. Carlos Avilés Mares

Ministerio de Energía y Minas, Dirección Gral.

Sectorial de Energía

Torre Oeste, Piso 17

Parque Central, Caracas

VENEZUELA

For address corrections send an e-mail towebmaster@enpep.dis.anl.gov 

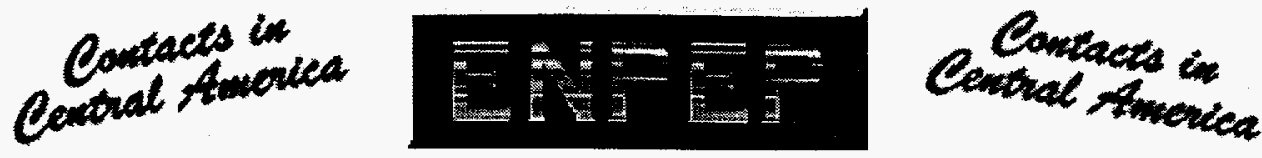

\section{COSTA RICA}

WASP-III (portion of ENPEP)

Ing. Héctor Vargas F.

Instituto Costarricense de Electricidad (ICE)

Apdo.10032 - San José

COSTA RICA

\section{CUBA}

$M A E D-1$

Mr. Ector Delgado

Unión Eléctrica

Ministerio de la Industria Básica

Habana

CUBA

\section{DOMINICAN REPUBLIC}

WASP-III (portion of ENPEP)

Ing. Marcelo Jorge Pérez

Corporación Dominicana de Electricidad

Santo Domingo, D.N.

DOMINICAN REPUBLIC

\section{EL SALVADOR}


WASP-III (portion of ENPEP)

Mr. Oscar R. Melgar

Comisión Ejecutiva

Hidroeléctrica del Río Lempa

9a. Calle Poniente No. 950

San Salvador

EL SALVADOR

\section{GUATEMALA}

MAED-1 \& WASP-III (portion of ENPEP)

Ing. Juan L. Guzmán R.

Instituto Nacional de Electrificación (INDE)

7a. Avenida 2-29, Zona 9

Unidad de Planificación del Sistema Eléctrico (UPSE-INDE)

Edificio "La Torre"

Guatemala City

GUATEMALA

\section{HAITI}

\section{WASP-III (portion of ENPEP)}

Mr. Reynold Desrouleaux

Rue Dantes Destouches

Boîte postale 1753

Port-au-Prince

HAITI

\section{JAMAICA}


WASP-III (portion of ENPEP)

Mr. Hopeton Heron

Manager, System Planning

Jamaica Public Service Co.

6 Knutsford Blvd.

Kingston 10

JAMAICA

NICARAGUA

WASP-III (portion of ENPEP)

Mr. Emilio Rappaccioli

Empresa Nacional de Luz y Fuerza

Instituto Nicaragüense de Energía

Apartado 55, Managua, D.C.

NICARAGUA

\section{PANAMA}

WASP-III (portion of ENPEP)

Mr. O. Rondell

Instituto de Recursos

Hidráulicos y Electrificación

Apartado 5285, Panamá 5

PANAMA

For address corrections send an e-mail to webmaster@enpep.dis.anl.gov 

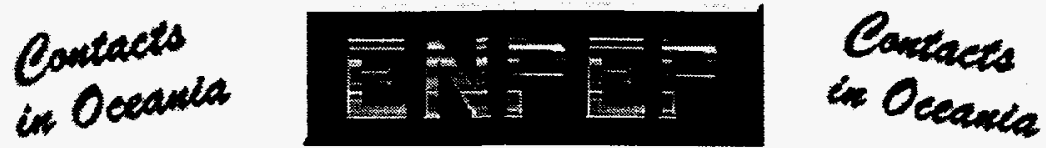

\section{AUSTRALIA}

MAED-1

Mr. V. Srinivasan

South Australian Office of Energy Planning

Wakefield House

30 Wakefield Street

5000 Adelaide, S. Australia

AUSTRALIA

\section{WASP-III (portion of ENPEP)}

Mr. J. R. Fredsall

Austr. Nuclear Science \& Tecnology

Lucas Height Research Laboratory

Lucas Height, Private Mailbag 1

N.S.W. 2232

AUSTRALIA

NEW ZEALAND

WASP-III (portion of ENPEP)

Mr. Keith Turner

New Zealand Electricity

Private Bag, Wellington

Rutherford House

23 Lambton Quay

Wellington

NEW ZEALAND

For address corrections send an e-mail towebmaster@enpep.dis.anl.gov 


\title{
BAHRAIN
}

\author{
ENPEP \\ Mr. Aref Saleh Khamis \\ Ministry of Finance and National Economy \\ P.O. Box 333 \\ Manama \\ BAHRAIN
}

\section{EGYPT}

\author{
ENPEP \\ $\underline{M A E D-1}$ \\ Mr. Hamed Aly Hamed Korkor \\ Organization for Energy Planning (OEP) \\ 1, Aisha Taymoryia Street \\ Garden City, Cairo \\ EGYPT \\ Dr. Emad El-Sharkawi \\ Chairman \\ Egyptian Electricity Authority - EEA \\ Nasr City - Abbassia \\ EGYPT \\ WASP-III (portion of ENPEP) \\ Eng. Maher Abaza \\ Nuclear Power Plants Authority \\ Ministry of Electricity and Energy \\ 4 Av. El-Nasr City, Cairo \\ EGYPT

\section{IRAN} \\ ENPEP \& WAPS-III (portion of ENPEP) \\ Mr. Msoud Shakiba \\ Iran Electric Organization \\ Director of Generation Planning Dept.
}


Vali-Asr Ave., Shahrdary St

P.O. Box 19835-359

Tehran

IRAN

\section{ISRAEL}

ENPEP

Mr. D. Soloveitchik

Ministry of Energy \& Infrastructure

234 Jaffa Street

91130 Jerusalem

ISRAEL
WASP-III (portion of ENPEP)

Mr. A. Barak

Israel Atomic Energy Commission

P.O. Box 7061. Tel-Aviv

ISRAEL

\section{JORDAN}

$\begin{array}{cc}\begin{array}{c}\text { Mr. Mahmoud Al-Ees } \\ \text { Ministry of Energy and Mines } \\ \text { P.O. Box 140027 Wadi Sier } \\ \text { Amman } \\ \text { JORDAN }\end{array} & \text { Jordan ED-1 \& WA } \\ & \\ \text { KUWAIT } & \\ & \text { ENPEP } \\ \text { Mr. Khelil Ben Afia } \\ \text { Ministry of Oil } \\ \text { P.O. Box 5077 } \\ \text { Safat } \\ \text { KUWAIT }\end{array}$

\section{SAUDI ARABIA}


ENPEP

Ms. Ayse Soysal

State Planning Organization

Sectoral Programming Department

Necatibey St. 108

Ankara

SAUDI ARABIA
MAED-1

\section{Dr. I. Al-Kharashi}

King Abdulaziz City

for Science and Technology

P.O. Box 6086

Riyad 11442

SUADI ARABIA

\section{WASP-III (portion of ENPEP)}

Mr. Mohd. Ali-Al-Tasan

Information Systems and Technical Services

Saudi Arabian National Centre for Science and Technology

P.O. Box 6086

Riyadh

SAUDI ARABIA

\section{SYRIA}

\section{WASP-III (portion of ENPEP)}

Mr. Khaled Homsi

Studies and Scientific Researches Centre

P.O. Box 4470

Damascus

SYRIA ARAB REPUBLIC

\section{TURKEY}

ENPEP

Ms. Ayse Soysal

State Planning Organization Sectoral Programming Department

Necatibey St. 108

Ankara

TURKEY
WASP-III (portion of ENPEP)

Ms. Nese Gencylmax

Generation Planning and Coordination Section Turkish Electricity Authority

Necatibey cad. 36

Ankara

TURKEY 
For address corrections send an e-mail to webmaster@enpep.dis.anl.gov 

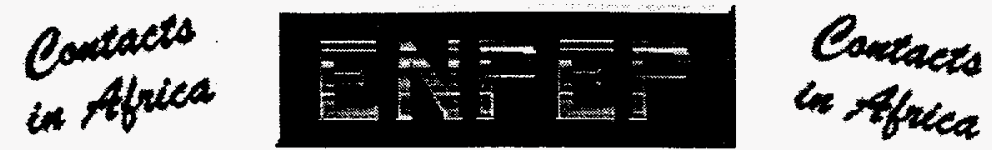

\section{ALGERIA}

ENPEP, MAED-1 \& WASP-III (portion of ENPEP)

Mr. Abdoun Rachid

Societé Nationale de l'electricité et du Gaz, SANELGAZ

2 Blvd. Colonel Krim Belkacem

Alger

ALGERIA

\section{EGYPT}

ENPEP

Mr. Hamed Aly Hamed Korkor

Organization for Energy Planning (OEP)

1, Aisha Taymoryia Street

Garden City, Cairo

EGYPT
MAED-1

Dr. Emad El-Sharkawi

Chairman

Egyptian Electricity Authority - EEA

Nasr City - Abbassia

EGYPT

WASP-III (portion of ENPEP)

Eng. Maher Abaza

Nuclear Power Plants Authority

Ministry of Electricity and Energy

4 Av. El-Nasr City, Cairo

EGYPT

\section{ETHIOPIA}




\title{
WASP-III (portion of ENPEP)
}

\section{Mr. Mekonnen Lulie}

Ethiopian Energy Authority

P.O. Box 486

Addis Ababa

ETHIOPIA

\section{GHANA}

MAED-1 \& WASP-III (portion of ENPEP)

\author{
Mr. Herbert Boadu
}

National Nuclear Research Institute

Ghana Atomic Energy Commission

P.O. Box 80, Legon-Accra

GHANA

\section{KENYA}

WASP-III (portion of ENPEP)

Mr. D. M. Mwangi

Kenya Power \& Lighting Co.

Electric House, Harambee Ave.

P.O. Box 30099

Nairobi

KENYA

\section{LIBYA}


MAED-1 \& WASP-III (portion of ENPEP)

Mr. Haddud H. Haddud

General Electric Co.

P.O. Box 668

Tripoli

LIBYA

\section{MADAGASCAR}
MAED-1
Mr. Gervais Rasamoelina
Jiro Sy Rano Malagasy
JIRAMA
149 , rue Rainandriamampandry
101 Antananarivo
MADAGASCAR

WASP-III (portion of ENPEP)

Mr. Majilo Ratsimiebo

Jiro Sy Rano Malagasy

149 , rue Rainandriamampandry

B.P. 200, Antananarivo 101

MADAGASCAR

\section{MAURITIUS}

MAED-1 \& WASP-III (portion of ENPEP)

Mr. P.M.K. Soonarane

Ministry of Energy. Water Resources \& Postal Services

Government Centre

Port Louis

MAURITIUS

\section{MOROCCO}


ENPEP

Mr. Mohamed Fadili

Office Nationale de l'Electricité

65, Rue Aspirant Lafuente

Casablanca

MOROCCO
WASP-III (portion of ENPEP)

Mr. Kettani Zine Laabidine Office Nationale de l'Electricité (ONE) 65, Rue Aspirant Lafuente, B.P. 498

Casablanca

MOROCCO

\section{NIGERIA}

\section{WASP-III (portion of ENPEP)}

Mr. D. A. Oyeyele

National Electricity Power Authority

Electricity Headquarters

24/25 Marina, P.M.B. 12030

Lagos

NIGERIA

\section{SUDAN}

ENPEP

Mr. Haroun Osman Sam

National Electricity Corporation (NEC)

P.O. Box 1380

Khartoum

SUDAN

\section{TANZANIA}


Ms. Justina P.L. Uisso

Prof. H. Y. Kayumbo

Ministry of Water, Energy and Minerals

P.O. Box 2000

P.O. Box 4302

Dar Es Salaam

Dar es Salaam

TANZANIA

TANZANIA

\title{
TUNISIA
}

ENPEP \& WASP-III (portion of ENPEP)

Mr. Hedi Turki

Societé Tunisienne de l'Electricité et du Gaz (STEG)

38 rue Kémal Ataturk

1021 Tunis

TUNISIA
MAED-1

\section{Mr. Ahmed Ounali}

Agence de Maitrise de

L'Energie - AME

8 rue Ibn El Jazzan

1002 Tunis

TUNISIA

MAED-1

Mr. Moncef El Aroui

Direction des Etudes et de la Planification (STEG)

38 rue Kémal Ataturk

1021 Tunis

TUNISIA

\author{
ZAMBIA \\ WASP-III (portion of ENPEP) \\ Dr. Japhet D. Sakala \\ Director, Corporate Affairs \\ Zambia Electric Supply Corporation \\ ZESCO \\ P.O. Box 33304 \\ Lusaka \\ ZAMBIA
}




\section{ZIMBABWE}

\section{MAED-1 \& WASP-III (portion of ENPEP)}

\section{Mr. D. Madzikanda}

Zimbabwe Electricity Supply Authority

System Planning

P.O Box 377

Harare

ZIMBABWE

For address corrections send an e-mail to webmaster@enpep.dis.anl.gov 

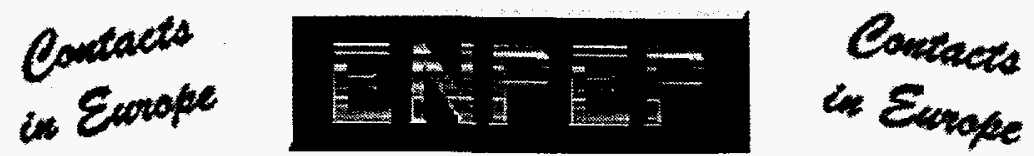

\section{ALBANIA}

$M A E D-1 \& W A S P-I I I$ (portion of ENPEP)

Ms. Irena Jorgoni

Chief of Energy Economics Department

Council of Ministers

National Committee of Energy

Bulevardi "Desmoret e Kombit

Tirana

ALBANIA

\section{BELARUS}

ENPEP, MAED-1 \& WASP-III (portion of ENPEP)

Mr. Anatoly Yakoushev

Institute of Power Engineering Problems

Academy of Sciences of Belarus, Sonsny

220109 Minsk

Republic of BELARUS

\section{BULGARIA}

ENPEP \& WASP-III (portion of ENPEP)

$M A E D-1$

Mr. Dimitar Stoytchev

National Electric Company

Energokibernetika

Triaditza 8, 1000 Sofia

BULGARIA
Mr. Dimitar Stoytchev

CEE Powercybernetics

8 Triaditza Str.

1000 Sofia

BULGARIA

\section{CROATIA}


ENPEP

Mr. Boris Maksijan

Ministry of Economy

Avenija Vukovar 78

41000 Zagreb

CROATIA

\section{MAED-1 \& WASP-III (portion of ENPEP)}

Mr. Mladen Zeljko

Institut za Elektroprivredu i energetiku

Avenija Vukovar 37

41000 Zagreb

CROATIA

\section{CYPRUS}

ENPEP

Mr. George Kountouris

Chief Engineer \& General Manager

Electricity Authority of Cyprus

P.O. Box 4506

Nicosia

CYPRUS
WASP-III (portion of ENPEP)

Mr. Costas Charalambous

Planning Department

Electricity Authority of Cyprus

15 Photis Pittas Street

P.O. Box 4506

Nicosia

CYPRUS

\section{CZECH REPUBLIC}

MAED-1

Mr. Jiri Spitz

Research Institute of Fuel \&

Energy Complex

Czechoslovak Atomic Energy

Commission

Slezska 9, 12029 Prague 2

CZECH REPUBLIC
WASP-III (portion of ENPEP)

Mr. Jiri Martinek

Research Institute of Fuel \& Energy Complex

Czechoslovak Atomic Energy Commission

Slezska 9, 12029 Prague 2

CZECH REPUBLIC

\section{ESTONIA}

WASP-III (portion of ENPEP)

Mr. Tanel Kaasik 
EESTI Energia

1, Estonia Pst.

EE0100 Tallinn

ESTONIA

FINLAND

\section{WASP-III (portion of ENPEP)}

Mr. Euro Tamminen

Technical Research Centre of Finland

VTT-ENERGY

P.O. Box 1606

SF - 02044 VTT - ESPOO

FINLAND

\section{FRANCE}

MAED-1 \& WASP-III (portion of ENPEP)

Mr. Bertrand Chateau

Institut Economique et Juridique de l'Energie

Université des Sciences Sociales de Grenoble

B.P. 47X, Grenoble Cedex F-38040

FRANCE

\section{GERMANY}

MAED-1 \& WASP-III (portion of ENPEP)

Mr. Reuter Albrecht

Institut für Energiewirtshaft

und Rationelle Energieanwendung

Universität Stuttgart, IKE

Pfaffenwaldring 31

Postfach 801140

7000 Stuttgart 80

GERMANY
WASP-III (portion of ENPEP)

Mr. K. Schippers

Institut fuer Elektrische Anlagen

und Energiewirtschaft - LL

RWTH Aachen, Schinkelstrasse 6

D-5100 Aachen

GERMANY 


\section{GREECE}

MAED-1 \& WASP-III (portion of ENPEP)

Mr. Spyros Vassos

Public Power Corporation

Department of Strategy and Planning

32 Arachovis Street

10681 Athens

GREECE

\section{HUNGARY}

\section{ENPEP \& WASP-III (portion of ENPEP)}

Mr. Milhály Bacskó

Hungarian Power Companies Ltd. (MVM)

Dept. of Power Plants Operation

Vam u. 5-7

H-1011 Budapest

HUNGARY
MAED-1

Mr. Péter Dörfner

Hungarian Electricity Board

(MVMT), Vam u. 5-7

H-1011 Budapest

HUNGARY

\section{ICELAND}

WASP-III (portion of ENPEP)

Mr. E. G. Hreinsson

University of Iceland

Faculty of Engineering

Hjardarhagi 2-6

107 Reykjavik

ICELAND

\section{ITALY}


WASP-III (portion of ENPEP)

Mr. A. Rivoiro

Ente Nazionale per l'Energia Elettrica

ENEL/DSR-CREI

Via A. Volta, 1

20093 Cologno Monzense

ITALY

\section{LITHUANIA}

MAED-1 \& WASP-III (portion of ENPEP)

Mr. Vaclovas Miskinis

Head of Department

Lithuanian Energy Institute

Breslaujos 3

3035 Kaunas

LITHUANIA

\section{MACEDONIA}

WASP-III (portion of ENPEP)

Prof. Dr. Tome Bosevski

Elektrotehnicki fakultet

Karpos II, bb, P.O Box 574

91000 Skopje

MACEDONIA 
Mr. Silvia Cociu

Department of Energy and Energy Resources

50 Mihai Eminescu Street

227012 Chishinev

MOLDOVA
Mr. Stefan Puiu

Department of Energy and Energy Resources

50 Mihai Eminescu Street

227012 Chishinev

MOLDOVA

\section{NORWAY}

MAED-1 \& WASP-III (portion of ENPEP)

\section{Mr. Bjorn Grinden}

Norwegian Electric Power Research Institute

N-7034 Trondheim

NORWAY

\section{POLAND}

ENPEP

\section{Mr. Andrzej Kerner}

Energy Information Center

Division of Energometrics

Mysia Street 2

P.O. Box 143

00-950 Warsaw

POLAND
MAED-1 \& WASP-III (portion of ENPEP)

Mr. D. Lucjan Twardy

Electric Power and Lignite Board

Mysia 2

00-496 Warsaw

POLAND

\section{PORTUGAL}




ENPEP
Mr. Joao Baptista
National Energy Plan
Ministry of Industry and Energy
Rua da Beneficencia, 241, $4^{\circ}$
1600 Lisboa
PORTUGAL

WASP-III (portion of ENPEP)

Mr. Jorge R. Machado

Electricidade de Portugal

Gabinete de Planeamento

Rua Sa da Bandeira 567

Apartado 99, 4009 Porto Cedex

PORTUGAL

\section{ROMANIA}

ENPEP, MAED-1 \& WASP-III (portion of ENPEP)

Ms. Anca Popescu

Institute of Power Studies and Design (ISPE)

1 BD. Lacul Tei

P.O. Box 30

R72301 Bucharest

ROMANIA

\section{RUSSIA}

ENPEP

Mr. Alexander Shibanov

Main Computing Centre

Ministry of Fuel and Energy of the Russian Federation

Kitaisvky pr. 7

134074 Moscow

RUSSIA FEDERATION
WASP-III (portion of ENPEP)

Mr. V. S. Kagramanian Institute of Physics and Power Power Enginnering (IPPE)

Bondarenko Square I 249020 Obninsk

Kaluga Region RUSSIA FEDERATION

\section{SLOVENIA}


MAED-I \& WASP-III (portion of ENPEP)

Mr. Zvonko Bregar

Milan Bidmae Electroinstitute

Hajdrihova 2

61000 LjUbljana

SLOVENIA

\section{SLOVAKIA}

ENPEP, MAED-1 \& WASP-III (portion of ENPEP)

Mr. Ivan Mojik

Director of Air Protection Department

Ministry of the Environment

Hlboká 2

81235 Bratislava

SLOVAKIA

\section{SPAIN}

ENPEP

Mr. Francisco Mingot Buades

Centro de Investigaciones

Energéticas,

Medioambientales y Tecnológicas

(CIEMAT)

Avenida Complutense 22

28040 Madrid

SPAIN
ENPEP \& WASP-III (portion of ENPEP)

\author{
Mr. A. González de Ubieta \\ Unidad Eléctrica S.A. (UNESA) \\ C. Francisco Gervás No. 3 \\ Madrid 20 \\ SPAIN
}


WASP-III (portion of ENPEP)

Dr. Jan Sundell

The Swedish State Power Board

S-16287 Vällingby

SWEDEN

\section{SWITZERLAND}

\section{WASP-III (portion of ENPEP)}

\section{Mr. E. Gnansounou}

Institut d'hydraulique et d'énergie

LASEN-Laboratoire de systémes énérgetiques

Ecole polytechnique fédérale de Lausanne - GCB (Ecublens)

CH-1015 Lausanne

SWITZWERLAND

\section{TURKEY}

\section{MAED-1}

Mr. Sefik Ozanozcu

Enerji ve Tabil Kaynaklar

Basbakanligi, Konya Yalu

Ankara

TURKEY 


\title{
WASP-III (portion of ENPEP)
}

\author{
Dr. H. W. Whittington \\ Department of Electrical Eng. \\ The University of Edinburgh \\ The King's Building \\ Mayfield Road \\ Edinburgh EH9 3JL \\ Scotland \\ U.K.
}

\section{UKRAINE}

ENPEP \& WASP-III (portion of ENPEP)

Ms. Elena Ivanovna Dyakova

Reactor Physics Section of the Nuclear

Power Dept. of Nuclear Research Institute of the Ukrainian National Academy of Sciences

252650, Kiev-20

UKRAINE

\section{YUGOSLAVIA}

\section{ENPEP, MAED-1, WASP-III (portion of ENPEP)}

\section{Mr. Zoran Sretenovic}

Union of Yugoslav Electric Power Industry, JUGEL

Development and International Relations Division

11000 Belgrade

Balkanska 13

YUGOSLAVIA WASP-III (portion of
ENPEP)

Mr. A. Kocic

Boris Kidric Institute

Nuclear Engineering Lab.

P.O. Box 522, YU-11001

Beograd

YUGOSLAVIA

For address corrections send an e-mail to webmaster@enpep.dis.anl.gov 